\title{
Neuroprotective Potentials of Marine Algae and Their Bioactive Metabolites: Pharmacological Insights and Therapeutic Advances
}

\author{
Md. Abdul Hannan 1,2®), Raju Dash ${ }^{1}{ }^{(D)}$, Md. Nazmul Haque ${ }^{3}\left(\mathbb{D}\right.$, Md. Mohibbullah $^{4}$, \\ Abdullah Al Mamun Sohag ${ }^{2}$, Md. Ataur Rahman ${ }^{5}\left(\mathbb{D}\right.$, Md Jamal Uddin $^{6,7}$ (D) Mahboob Alam ${ }^{1,8}$ \\ and Il Soo Moon ${ }^{1, *(\mathbb{D})}$ \\ 1 Department of Anatomy, Dongguk University College of Medicine, Gyeongju 38066, Korea; \\ hannanbau@gmail.com (M.A.H.); rajudash.bgctub@gmail.com (R.D.); mahboobchem@gmail.com (M.A.) \\ 2 Department of Biochemistry and Molecular Biology, Bangladesh Agricultural University, Mymensingh 2202, \\ Bangladesh; sohag2010bmb.sust@gmail.com \\ 3 Department of Fisheries Biology and Genetics, Patuakhali Science and Technology University, Patuakhali \\ 8602, Bangladesh; habib.332@gmail.com \\ 4 Department of Fishing and Post Harvest Technology, Sher-e-Bangla Agricultural University, Sher-e-Bangla \\ Nagar, Dhaka 1207, Bangladesh; mmohib08@gmail.com \\ 5 Center for Neuroscience, Korea Institute of Science and Technology (KIST), Seoul 02792, Korea; \\ ataur1981rahman@hotmail.com \\ 6 Graduate School of Pharmaceutical Sciences, College of Pharmacy, Ewha Womans University, Seoul 03760, \\ Korea; hasan800920@gmail.com \\ 7 ABEx Bio-Research Center, East Azampur, Dhaka 1230, Bangladesh \\ 8 Division of Chemistry and Biotechnology, Dongguk University, Gyeongju 780-714, Korea \\ * Correspondence: moonis@dongguk.ac.kr; Tel.: +82-54-770-2414; Fax: +82-54-770-2447
}

Received: 20 May 2020; Accepted: 25 June 2020; Published: 1 July 2020

\begin{abstract}
Beyond their significant contribution to the dietary and industrial supplies, marine algae are considered to be a potential source of some unique metabolites with diverse health benefits. The pharmacological properties, such as antioxidant, anti-inflammatory, cholesterol homeostasis, protein clearance and anti-amyloidogenic potentials of algal metabolites endorse their protective efficacy against oxidative stress, neuroinflammation, mitochondrial dysfunction, and impaired proteostasis which are known to be implicated in the pathophysiology of neurodegenerative disorders and the associated complications after cerebral ischemia and brain injuries. As was evident in various preclinical studies, algal compounds conferred neuroprotection against a wide range of neurotoxic stressors, such as oxygen/glucose deprivation, hydrogen peroxide, glutamate, amyloid $\beta$, or 1-methyl-4-phenylpyridinium $\left(\mathrm{MPP}^{+}\right.$) and, therefore, hold therapeutic promise for brain disorders. While a significant number of algal compounds with promising neuroprotective capacity have been identified over the last decades, a few of them have had access to clinical trials. However, the recent approval of an algal oligosaccharide, sodium oligomannate, for the treatment of Alzheimer's disease enlightened the future of marine algae-based drug discovery. In this review, we briefly outline the pathophysiology of neurodegenerative diseases and brain injuries for identifying the targets of pharmacological intervention, and then review the literature on the neuroprotective potentials of algal compounds along with the underlying pharmacological mechanism, and present an appraisal on the recent therapeutic advances. We also propose a rational strategy to facilitate algal metabolites-based drug development.
\end{abstract}

Keywords: seaweed; secondary metabolites; neuroprotection; Alzheimer's disease; Parkinson's disease; ischemic stroke; computer-aided drug discovery 


\section{Introduction}

Neurons and supporting cells of the brain encounter degenerative changes during physiological or pathological aging, ischemic stroke, or other brain injuries [1]. The degenerative brain disorders such as Alzheimer's disease (AD) and Parkinson's diseases (PD) are the consequence of pathological brain aging, which are characterized by the region-specific loss of neurons [2]. Globally, these diseases account for the major causes of dementia among the elderly [3]. Although the exact etiologies of these brain disorders are not revealed yet, they share some common pathophysiology, such as oxidative stress (OS), neuroinflammation, mitochondrial dysfunction, protein misfolding, and defective protein clearance system that, in turn, make these diseases complicated [4,5], whereas, ischemic, traumatic, and other brain injuries, if not fatal, ensue secondary damage and constitute the appreciable causes of cognitive deficits among patients. Like neurodegenerative disorders, brain injuries also follow the same pathophysiology [6,7]. Whatever the forms of dementia disorder, the current therapeutic option can only alleviate symptoms, rather than halting the disease progression. Moreover, current drugs are associated with multiple side effects. Considering the tremendous social and economic impact of these diseases, scientists are, therefore, paying research efforts to discover the potential therapeutic agents that can target disease pathogenesis without causing undesirable effects in patient's health. Although synthetic drugs have some advantages such as easy to develop, naturally-derived compounds have received priority as they are relatively well-tolerated. Natural compounds have been claimed to show anti-inflammatory, antioxidant, and immunomodulatory effects [8]. Compounds showing multiple pharmacological effects offer a better solution for the remedy of neurological disorders with complex pathomechanisms [9]. In the published literature, a significant quantity of natural products has been reported to show neuroprotective activity against a wide range of toxic insults $[10,11]$. Some of them have shown therapeutic promise in preclinical studies [12] and clinical trials [13,14].

Macroalgae, also known as seaweed, are among the highly abundant marine lives and potentially contribute to the renewable resources for food and industrial products [15-17]. Beyond this importance, algal metabolites, such as phenolics, alkaloids, terpenoids, carotenoids, phytosterols, and polysaccharides have attracted much attention to medicinal chemistry due to their structural uniqueness and functional diversity [17-20]. These biofunctional compounds have shown to provide neuroprotection in preclinical models of neurodegenerative diseases, ischemic stroke, brain trauma, diabetes, and obesity, among many others, owing to their antioxidant, anti-inflammatory, and immunomodulatory capacities [21-28]. Evidence suggests that algal metabolites, particularly fucoxanthin, fucosterol, and fucoidan could be potential leads for the development of therapy against CNS diseases [22,29-31]. Although the algal metabolite-based drug discovery progresses very slowly, the discovery of sodium oligomannate and its conditional approval as an anti-AD drug [32] raises hope for the future development of potential therapeutic agents from marine algae.

Over the last decade, some excellent works reviewed the neuroprotective effects of marine algae and their metabolites [21-23,29,33-35]. However, some of these reviews limited their scope either to a single pathogenic mechanism such as neuroinflammation [22] or to categorical brain disorders such as $\mathrm{AD}$ or PD $[22,23,29,34,35]$. Others have reviewed literature published a decade or half a decade ago $[23,36]$. Moreover, a few of them included reports that cover ischemic or other brain injuries. In the meantime, information on some potential algal compounds with neuroprotective activity has appeared in the scientific platform and there has also been significant progress in the clinical aspect. Addressing the knowledge gap and the possible limitations, offering a comprehensive review updating information on the neuroprotective effects of algal compounds and their therapeutic advances is timely. In this comprehensive review, we first briefly outline the pathobiology of neurodegenerative disorders, ischemic stroke, and traumatic brain injury and then provide pharmacological insights into the neuroprotective potentials of algal metabolites and highlight the recent progress in algae-based drug discovery. Finally, the rational strategy for algal compounds-based drug development has been discussed. 


\section{Pathophysiology of Brain Disorders}

\subsection{Neurodegenerative Disorders ( $A D$ and $P D)$}

Neurodegenerative disorders, including $\mathrm{AD}$ and $\mathrm{PD}$, are of major public health concern and contribute to the prime causes of dementia among elderly people. The pathological hallmarks of AD include extracellular deposition of amyloid plaque and intraneuronal aggregation of neurofibrillary tangles (NFT) [37]. On the other hand, PD is characterized by the degeneration of dopaminergic neurons in the substantia nigra [37] with the pathological hallmark of intraneuronal aggregation of $\alpha$-synuclein [38]. Although the exact pathophysiology of these brain disorders remains elusive, it has been demonstrated that OS, neuroinflammation, mitochondrial dysfunction, and protein misfolding largely contribute to their development [37]. OS and neuroinflammation are two considerably diverse disease processes in many pathological events [39]. Conversely, they are interplayed with each other in the entire disease process. Thus, inhibition of neuroinflammation may reduce the OS and vice versa.

Oxidative stress (OS) is a pathological condition that develops when the production of reactive oxygen species (ROS) reaches an excessive level with lower efficiency of the cellular antioxidant defense system [40]. Factors contributing to OS in the brain include excitotoxicity, depletion of the cellular antioxidant system, high susceptibility to lipid peroxidation, and high oxygen demand [41]. OS may lead to mitochondrial dysfunction, which further results in the excessive ROS generation and establishes a vicious cycle of OS [42,43]. Moreover, the endoplasmic reticulum (ER), a site for protein folding, also takes part in ROS generation [44]. Protein misfolding in ER results in ER stress that is further responsible for ROS production [45]. ROS potentially contributes to the damage of cells through compromising the structure and function of biomolecules, including lipid peroxidation, protein oxidation, and deoxyribonucleic acid (DNA) damage, which eventually install neurodegeneration [38].

Neuroinflammation is another inevitable pathogenic factor of many neurodegenerative disorders [46]. Microglial activation is the major contributor to neuroinflammation [46]. A range of stimuli, including infection, trauma, toxic insults, and ischemia, may initiate microglial activation and disrupt the central nervous system (CNS) homeostasis [47,48]. Once activated, microglia released pro-inflammatory and neurotoxic elements, like chemokines, cytokines, proteases, eicosanoids, ROS, and excitatory amino acids [47]. All of these elements are documented as a key player in neuroinflammation-associated OS as well as chronic neurodegeneration [49]. The deposition of misfolded proteins, as evident in the major NDD, can also induce an inflammatory response, which further causes OS [50].

Dysregulation of cholesterol homeostasis is also a critical factor that could induce OS and inflammation, and thus may contribute to the pathogenesis of major brain disorders [51]. This disturbance in cholesterol metabolism in the brain is under the regulation of a cholesterol transport mechanism. Liver $X$ receptor beta (LXR- $\beta$ ), once activated, promotes multiple genes that regulate reverse cholesterol transport and thus confers neuroprotection [52,53]. For instance, LXR- $\beta$ agonist enhanced survival of dopaminergic neurons [54] and reduced the burden of mutant huntingtin [55] as well as promoted amyloid $\beta$ (A $\beta$ ) clearance [56]. With the significant evidence of the implication of OS, neuroinflammation, and cholesterol dyshomeostasis in the pathobiology of neurodegenerative disorders, these pathological factors could be targeted for the development of potential therapeutics.

\subsection{Ischemic Stroke}

Ischemic stroke is responsible for the second-highest number of deaths and disability around the world [57]. It is a pathological condition resulting from sudden occlusion of blood supply to the brain. If the patient survives, the affected brain areas accompany the secondary damage due to the restoration of blood flow and reoxygenation. This ischemia/reperfusion (I/R) event initiates mitochondrial ROS generation [58] and subsequent inflammatory response [59].

Mitochondrial ROS is not only a crucial early driver of acute damage but is also considered an initiator of the consequence of a series of pathological features that develop over time following the 
reperfusion [60]. Initially, upon reperfusion, the burst of ROS production results in oxidative damage to mitochondria, and thereby disrupts ATP production [61], which ultimately initiates neuronal cell death cascades [62]. ROS-mediated mitochondrial damage further installs the inflammatory response via the activation of microglia and astrocytes as well as an influx of immune cells recruited by cytokines, adhesion molecules, and chemokines across the activated cerebral blood vessels [63]. This activation of the innate immunity triggers nuclear factor-kappa-B (NF- $\kappa \mathrm{B})$-mediated production of numerous inflammatory cytokines that contribute to I / R injury [64]. Therefore, targeting OS and inflammatory response could be imperative to develop novel therapeutic strategies for the management of stroke.

\subsection{Traumatic Brain Injury}

Traumatic brain injury (TBI), an acquired brain injury caused by an external force or shock, is also considered to be a major cause of death globally, particularly in countries with a frequent incidence of traffic accidents [65]. Despite significant medical advances in recent times, the clinical outcomes of severely head-injured patients are not satisfactory.

As in ischemic stroke, mechanisms underlying the damages to the brain tissue with TBI are categorized into two classes: primary and secondary damages. Primary damage that irreversibly involves the mechanical damage of the skull and the brain has been complicated following the brain contusions, rupturing blood vessels, axonal injuries, and intracranial hemorrhages [66], whereas the secondary damage causes neuronal degeneration over time due to various biochemical changes such as OS, excitotoxicity, inflammation, and mitochondrial dysfunction [67]. Following TBI, various OS markers such as lipid peroxidation products, oxidized protein moieties, and DNA damage products accumulate in the brain while antioxidants and enzymes molecules such as glutathione (GSH), glutathione peroxidase (GPx), glutathione reductase (GR), glutathione S-transferases (GST), superoxide dismutase (SOD), and catalase (CAT) markedly decline [68]. It is suggested that treatment modalities associated with conferring neuroprotection on injured brain tissue and regeneration at the recovery stage of injured neurons have greater promise to restore at the site of brain injury following TBI.

\section{Neuropharmacological Potentials of Marine Algae and Their Metabolites: Evidence from In Vitro Studies}

Several compounds of diverse chemical classes have been reported from three major groups (brown, red, and green algae) of marine algae (Figures 1-4). Neuropharmacological properties of these compounds reported in various in vitro models are compiled (Table 1) and discussed in the following subsections. Besides bioactive compounds, macroalgae that have shown promising neuroactive potentials, and thus demand further attention are also mentioned.

\subsection{Antioxidant Activity}

Marine algae-derived compounds have been reported to exhibit strong antioxidant property (Table 1), and thus may protect against oxidative damage. For example, fucoxanthin, a carotenoid from Sargassum siliquastrum, attenuated OS-induced DNA damage [69]. Fucoxanthin also prevented $\mathrm{H}_{2} \mathrm{O}_{2}$-induced DNA damage, which was associated with increased production of GSH, and expression of SOD [36]. Moreover, fucoxanthin promoted antioxidant defense in lipopolysaccharide (LPS)-activated BV-2 microglia by activating nuclear factor erythroid 2-related factor 2 (Nrf2)/heme oxygenase-1 (HO-1) pathway and cell survival through activating cAMP-dependent protein kinase (PKA)/cAMP response element-binding (CREB) pathway and increasing BDNF secretion [70]. Fucosterol raised cellular antioxidant enzymes, such as SOD, GPx, and CAT in experimental rats [71]. Jung and colleagues demonstrated that fucosterol prevented ROS production in tert-butyl hydroperoxide (t-BHP)-induced RAW264.7 macrophages [72]. In addition, fucosterol conferred protection from oxidative damage in HepG2 cells by raising the GSH level [73] and in lung epithelial cells by increasing the expression of SOD, CAT, and HO-1, and nuclear translocation of Nrf2 [74]. Glycoprotein of U. pinnatifida improved SOD activity (53.45\%) and inhibited xanthine oxidase (Xox) 
activity (82.05\%) [75]. Diphlorethohydroxycarmalol and 6,6'-bieckol from Ishige okamurae exhibited antioxidant activity and reduced intracellular ROS level in RAW264.7 cells [76]. Sulfated polysaccharide fractions from Porphyra haitanesis showed antioxidant activity and inhibited Lipid peroxidation in rat liver microsome [77]. Porphyran from Porphyra yezoensis showed superoxide anion and hydroxyl radical scavenging activity [78].

A

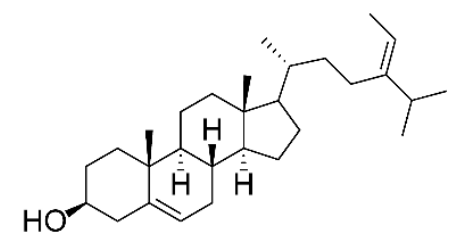

Fucosterol

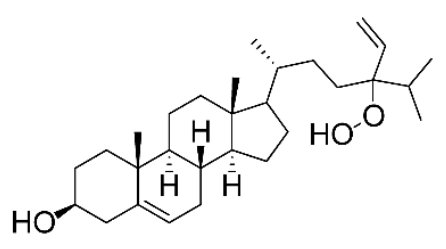

24-hydroperoxy-24-vinyl-cholesterol

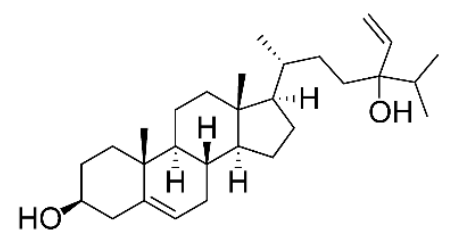

Saringosterol

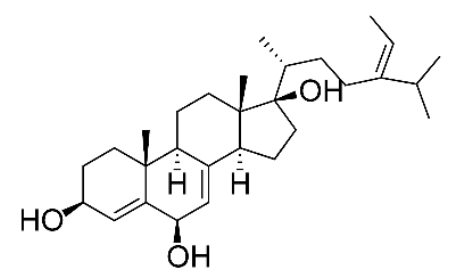

3,6,17-trihydroxy-stigmasta-4,7,24(28)-triene

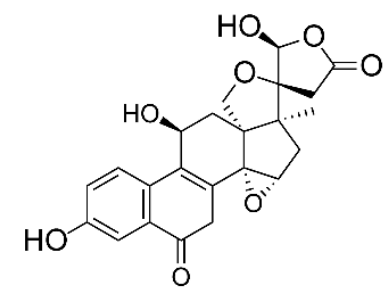

14,15,18,20-diepoxyturbinarin

B<smiles>CC(C)=CCC/C(=C\CC/C(C)=C/CC/C(C)=C/CC1=CC(=O)C=C(C)C1=O)C(=O)O[Mg]</smiles>

Figure 1. Chemical structure of sterols (A) and plastoquinones (B) of marine algae. 


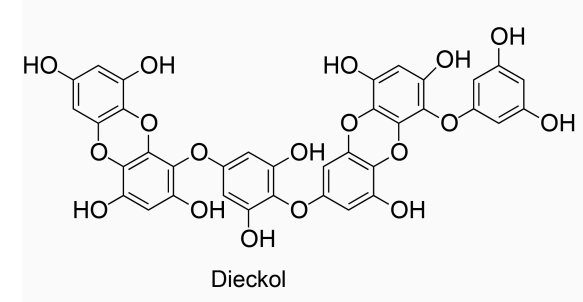<smiles>Oc1cc(O)cc(Oc2c(O)cc(O)c3c2Oc2cc(O)cc(O)c2O3)c1</smiles>

Eckol<smiles>Oc1cc(O)cc(-c2c(O)cc3c(c2O)Oc2cc(Oc4c(O)cc(O)cc4O)c(O)c(O)c2O3)c1</smiles>

Diphlorethohydroxycarmalol<smiles>Oc1cc(O)cc(Oc2c(O)cc(O)c3c2Oc2c(O)cc(O)cc2Oc2c(O)cc(O)cc2O3)c1</smiles>

2-Phloroeckol<smiles></smiles>

7-Phloroeckol

Triphloroethol A<smiles>Oc1cc(O)cc(Oc2c(O)cc(O)c3oc4c(Oc5cc(O)cc(O)c5O)c(O)cc(O)c4c23)c1</smiles>

Phlorofucofuroeckol A

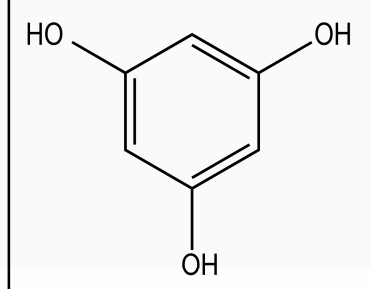

Phloroglucinol<smiles>O=C(OCCOc1ccccc1)Oc1c(O)cc(O)c2c1Oc1cc3oc4c(Oc5cc(O)cc(O)c5)c(O)cc(O)c4c3c(O)c1O2</smiles><smiles>Oc1cc(O)c2c(c1)Oc1c(O)cc(O)c(c1O)Oc1c(O)cc(O)cc1O2</smiles>

Dioxinodehydroeckol

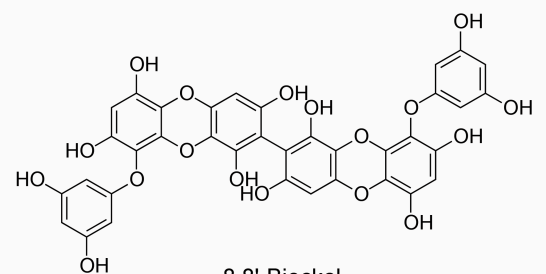<smiles></smiles><smiles></smiles>

Eckstolonol

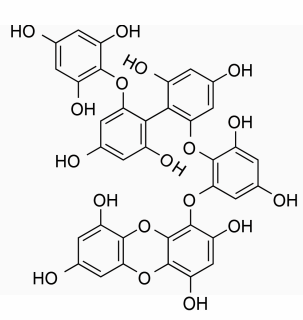

Eckmaxol

Figure 2. Chemical structure of phlorotannin of marine algae. 
A<smiles></smiles>

Caulerpin<smiles>COC(=O)C(/C=C1\NC(=O)c2ccccc2N1)=C1\Nc2ccccc2C1=O</smiles>

Racemosin A<smiles>CC(=O)CC/C=C(\C)CCC/C(C)=C\C(=O)CC(C)C</smiles>

(5E,10Z)-6,10,14trimethylpentadeca-5,10-dien-2,12-dione

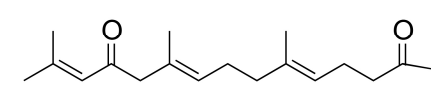

(5E,9E,13E)-6,10,14-

trimethylpentadeca-5,9,13-trien-2,12-dione

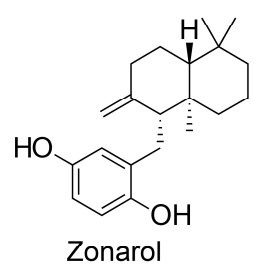

Zonarol

C

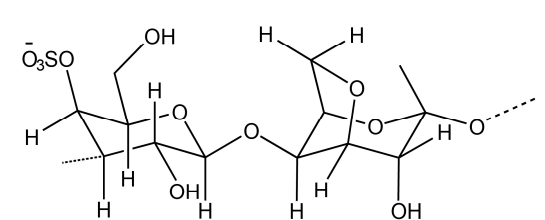

k-Carrageenan

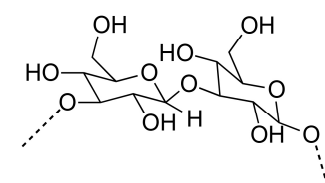

Laminarin

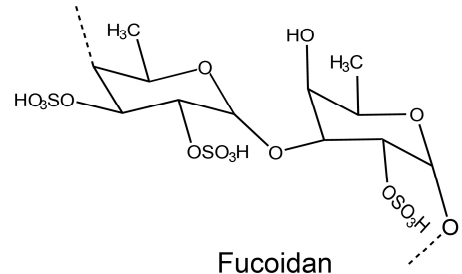

Fucoidan

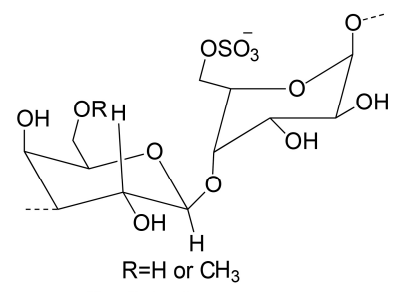

Sulfated agaran

Figure 3. Chemical structure of alkaloids (A), sesquiterpenes (B) and polysaccharides (C) of marine algae. 


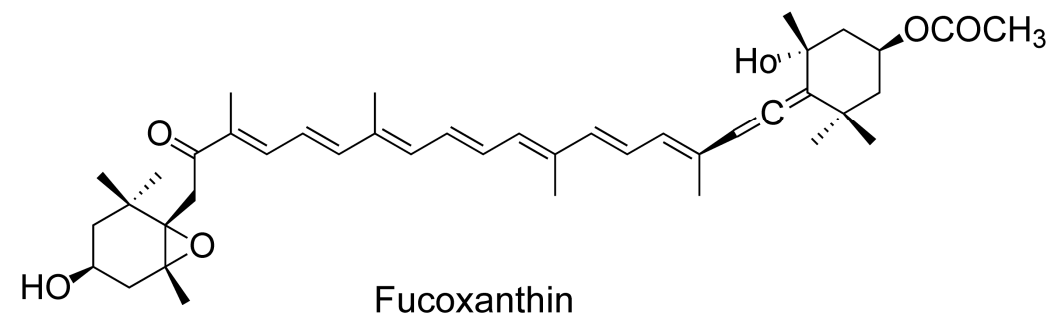<smiles>CC(C)=CCCC(C)(O)C1CC=C(C)CC1</smiles>

a-Bisabolol<smiles>C[S+](C)CCC(=O)[O-]</smiles>

Dimethylsulfoniopropionate Tramiprosate

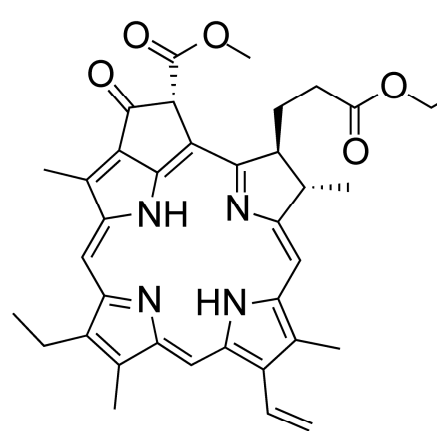

Pheophytin A

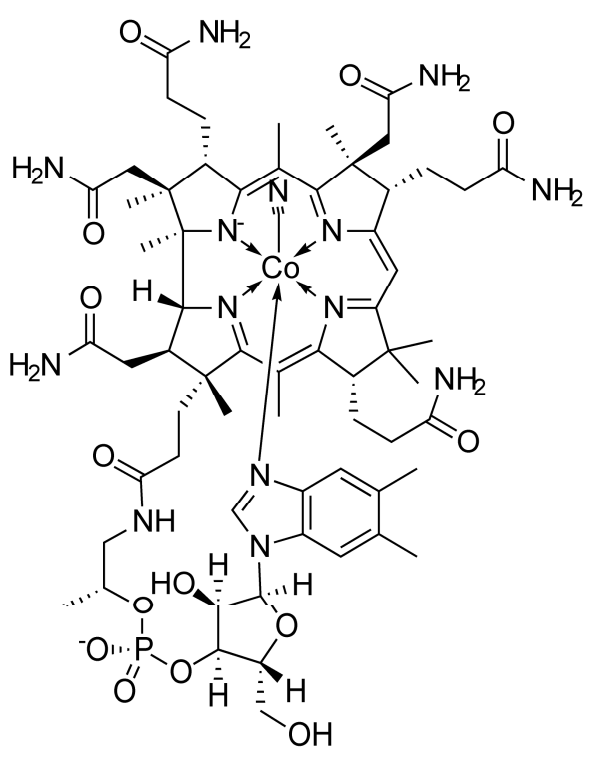

Vitamin B12

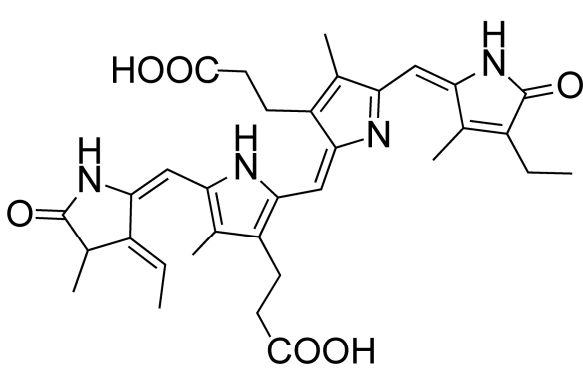

C-phycocyanin<smiles>OCC(CO)OC1OC(CO)C(O)C(O)C1O</smiles>

Floridoside

Figure 4. Chemical structure of miscellaneous compounds from marine algae. 
In addition, a great number of marine algae have shown antioxidant activity, including Sargassum polycystum and Laurencia obtusa [79], Gelidium foliaceum, and Codium duthieae [80], to mention a few.

\subsection{Anti-Inflammatory Activity}

An appreciable number of algal compounds have been reported for anti-inflammatory activity (Table 1). Fucoxanthin, a common carotenoid of brown algae, attenuated inflammation, and OS in glial cells $[36,70]$. In A $\beta 42$-induced BV2 cells, fucoxanthin attenuated inflammatory response, which was manifested by decreased secretion of proinflammatory mediators, such as tumor necrosis factor-alpha (TNF- $\alpha$ ), interleukin (IL)-6, IL-1 $\beta$ and prostaglandin $\mathrm{E}_{2}\left(\mathrm{PGE}_{2}\right)$ and reduced expression of inducible nitric oxide synthase (iNOS) and cyclooxygenase-2 (COX-2), and by lowering the phosphorylation of mitogen-activated protein kinase (MAPK) pathway [36]. In LPS-activated BV-2 microglia, fucoxanthin protected against neuroinflammation by lowering the expression of iNOS and COX-2 and reducing the secretion of inflammatory factors such as TNF- $\alpha, \mathrm{IL}-6, \mathrm{PGE}_{2}$, and nitric oxide (NO) that involved inhibition of protein kinase B (Akt)/NF- $\mathrm{kB}$ and MAPKs/ activating protein-1 (AP-1) pathways [70].

The anti-inflammatory activity of fucosterol has recently been reviewed [81]. In brief, fucosterol exhibited anti-inflammatory action [82] and attenuated LPS-induced inflammation in RAW 264.7 macrophage [72]; [83] and alveolar macrophage [84]. Fucosterol also protected against LPS- or A $\beta$-mediated neuroinflammation in activated microglial cells [85]. Several phlorotannins, such as dieckol [86], phlorofucofuroeckol A [87] and phlorofucofuroeckol B [88], 6,6'-bieckol [89], and 8,8'-bieckol [90] isolated from Ecklonia spp have been reported for their anti-inflammatory activities that involved suppression of NF-KB and MAPK pathways.

Algal polysaccharides are known to act as anti-inflammatory agents [91]. Fucoidan, a sulfated polysaccharide attenuated inflammatory response in LPS-stimulated BV2 microglia by suppressing NF- $\mathrm{KB}$ and extracellular signal-regulated kinases (ERK)/MAPK/Akt pathways [92]. In another study, fucoidan decreased the generation ROS and TNF- $\alpha$ in LPS-induced primary microglia [93]. k-Carrageenan oligosaccharides and its desulfated derivatives from red algae attenuated TNF- $\alpha$ production and showed anti-inflammatory activity in LPS-activated microglia [94]. Porphyran from Porphyra yezoensis attenuated nitric oxide (NO) generation in LPS-stimulated RAW264.7 cells by suppressing iNOS expression $[78,95]$. Treatment with sulfated oligosaccharides of Ulva lactuca and Enteromorpha prolifera reduced inflammatory factors and downregulated the expression of p53 and fork-head box protein O1 (FOXO1) genes and upregulated the expression of Sirt1 gene in SAMP8 mice [96]. Alginate-derived oligosaccharide inhibited the expression of inflammatory enzymes and secretion of proinflammatory cytokines in LPS/A $\beta$-induced BV2 microglia. This oligosaccharide also reduced the expression of toll-like receptor 4 (TLR4) and NF-kB [97]. Priming of LPS-stimulated primary microglia and astrocytes with seleno-polymannuronate (Se-PM) reduced the expression of inflammatory enzymes and the production of inflammatory mediators by suppressing NF- $\mathrm{kB}$ and MAPK signaling [98]. Sargachromenol isolated from Sargassum micracanthum attenuated inflammatory response in LPS-induced RAW 264.7 macrophages [99]. Kang and colleagues reported that sargaquinoic acid of Sargassum siliquastrum suppressed inflammatory response in LPS-stimulated RAW 264.7 macrophages by downregulating NF- $\mathrm{kB}$ and c-JNK pathways [100]. Pretreatment of LPS-stimulated BV-2 microglial cells with floridoside inhibited inflammation by blocking p38/ERK phosphorylation [101]. Glycoprotein from U. pinnatifida (UPGP) reduced the expression of inflammatory enzymes and NO synthesis in LPS-stimulated RAW 264.7 macrophage [75]. Moreover, several algal alkaloids such as caulerpin, racemosin A-C, and caulersin were shown to have anti-inflammatory activity [102]. 
In addition, several marine algae have been reported to show anti-inflammatory properties in various experimental models, for instance, Ecklonia cava [103], Myagropsis myagroides [104,105], Sargassum serratifolium [106], and three Malaysian seaweeds (Padina australis, Sargassum polycystum, and Caulerpa racemosa) [107] in LPS-stimulated murine BV2 microglia; Ulva conglobata in interferon gamma-induced BV2 cells [108]; Sargassum fulvellum [109], Sargassum horneri [110], Myagropsis myagroides [111,112] in LPS-stimulated RAW 264.7 macrophage cells and Sargassum serratifolium in LPS-stimulated mouse peritoneal macrophages [113]. Owing to their capacity to modulate various inflammatory pathways, these algae and their respective compounds have shown encouraging effects in protecting various cell types from the inflammatory response.

\subsection{Anticholinesterase Activity}

Currently prescribed anti-AD drugs are mostly based on the inhibition of cholinesterase activity. Several algal metabolites have been reported to inhibit cholinesterase activity (Table 1). For example, fucosterol and 24-hydroperoxy 24-vinylcholesterol isolated from E. stolonifera showed inhibitory activity against butyrylcholinesterase (BChE) [114]. Another study also demonstrated anticholinesterase activity of fucosterol [85]. Enzyme kinetics and computational analysis indicated a non-competitive mode of acetylcholinesterase (AChE) inhibition of fucosterol [115].

Fucoxanthin exhibited anti-BChE activity which was of mixed inhibition type [116], whereas Lin and colleagues demonstrated that fucoxanthin showed non-competitive inhibition against AChE [117]. $\alpha$-Bisabolol from Padina gymnospora showed inhibition against cholinesterase activity [118]. U. pinnatifida-derived glycoprotein showed $\mathrm{AChE}$ and $\mathrm{BChE}$ inhibitory activities [75].

The $\mathrm{IC}_{50}$ values for phloroglucinol, dibenzo [1,4] dioxine-2,4,7,9-tetraol and eckol from Ecklonia maxima range from 76.70 to $579.32 \mu \mathrm{M}$, with later two compounds possessing the highest AChE inhibitory activity [119]. Dieckol and phlorofucofuroeckol exhibited a similar anti-AChE activity [120]. Sargaquinoic acid and sargachromenol from Sargassum sagamianum have shown reasonable AChE inhibitory activity while the $\mathrm{BChE}$ inhibitory activity of sargaquinoic acid is 1000 -fold higher than for AChE [121]. Tyrosol and its derivative, 4-(1,2-dihydroxyethyl) phenol from Macrocystis angustifolia showed anti-AChE activity [122]. Meroterpenoids, such as sargahydroquinoic acid, sargachromenol, and sargaquinoic acid of S. serratifolium exhibited potent anti-AChE activity [123]. Among the phlorotannins tested 8,8'-bieckol showed potent anti-AChE activity [124].

In addition, the extracts from some marine algae have shown anti-cholinesterase properties. These include Halimeda cuneata [80], Padina australis [125], Botryococcus braunii and Nannochloropsis oculata [126], Cystoseira tamariscifolia and Cystoseira nodicaulis [127], Ishige foliacea [128], and Asparagopsis taxiformis [129]. 
Table 1. Summary on pharmacological effects, occurrence, effective dose, experimental model, cellular effects, potential pharmacological mechanism of algal metabolites.

\begin{tabular}{|c|c|c|c|c|c|c|c|c|}
\hline $\begin{array}{l}\text { Pharmacological } \\
\text { Effects }\end{array}$ & Compound (Class) & $\begin{array}{l}\text { Algal Source If } \\
\text { Any) }\end{array}$ & $\begin{array}{c}\text { Effective } \\
\text { Concentration }\end{array}$ & $\begin{array}{c}\text { Experimental Model (In } \\
\text { Vivo/In Vitro) }\end{array}$ & $\begin{array}{c}\text { Cellular } \\
\text { Effects/Significant } \\
\text { Findings }\end{array}$ & $\begin{array}{l}\text { Signaling } \\
\text { Pathways } \\
\text { Involved }\end{array}$ & $\begin{array}{l}\text { Pharmacological } \\
\text { Markers }\end{array}$ & Reference \\
\hline \multirow{8}{*}{$\begin{array}{l}\text { Antioxidant } \\
\text { activity }\end{array}$} & $\begin{array}{l}\text { Fucoxanthin } \\
\text { (carotenoids) }\end{array}$ & $\begin{array}{l}\text { Sargassum } \\
\text { siliquastrum }\end{array}$ & 50 and $100 \mu \mathrm{M}$ & $\begin{array}{l}\mathrm{H}_{2} \mathrm{O}_{2} \text {-induced cell } \\
\text { damage in kidney } \\
\text { fibroblast cells }\end{array}$ & $\begin{array}{c}\text { Attenuates oxidative } \\
\text { stress }\end{array}$ & n.d. & $\downarrow$ ROS level & [69] \\
\hline & Fucoxanthin & & 5,10 , and $50 \mu \mathrm{M}$ & $\begin{array}{l}\mathrm{H}_{2} \mathrm{O}_{2} \text { induced } \mathrm{BV} 2 \\
\text { microglial cells }\end{array}$ & Antioxidation & $\begin{array}{l}\text { Antioxidant } \\
\text { pathway }\end{array}$ & $\begin{array}{c}\downarrow R O S \\
\uparrow S O D \text { and GSH }\end{array}$ & [36] \\
\hline & $\begin{array}{c}\text { Fucosterol, } \\
\text { 3,6,17-trihydroxy- } \\
\text { stigmasta-4,7,24 } \\
\text { (28)-triene and 14,15, } \\
\text { 18,20-diepoxyturbinarin } \\
\text { (sterols) }\end{array}$ & Pelvetia siliquosa & $\begin{array}{c}\text { A seven day-dose } \\
\text { regimen at } \\
30 \mathrm{mg} / \mathrm{kg} / \text { day before } \\
\text { carbon tetrachloride } \\
\text { (CCl4) administration }\end{array}$ & Rat model & Antioxidation & n.d. & $\begin{array}{l}\text { TSOD, CAT, and } \\
\text { GPx }\end{array}$ & [71] \\
\hline & Fucosterol & $\begin{array}{l}\text { Eisenia bicyclis, } \\
\text { brown alga }\end{array}$ & $\begin{array}{c}25,50,100,200 \text {, and } \\
400 \mu \mathrm{M}\end{array}$ & $\begin{array}{l}\text { RAW } 264.7 \text { murine } \\
\text { macrophages } \\
\text { (t-BHP stimulated) }\end{array}$ & $\begin{array}{l}\text { Protects against } \\
\text { oxidative stress }\end{array}$ & n.d. & $\downarrow$ ROS generation & [72] \\
\hline & Fucosterol & $\begin{array}{c}\text { Ecklonia } \\
\text { stolonifera and } \\
\text { Eisenia bicyclis; } \\
\text { Brown algae }\end{array}$ & 25,50 , and $100 \mu \mathrm{M}$ & $\begin{array}{l}\text { tert-Butyl hydroperoxide- } \\
\text { and tacrine-induced } \\
\text { HepG2cell injury model }\end{array}$ & Antioxidation & n.d. & $\begin{array}{l}\downarrow \text { ROS generation } \\
\uparrow G S H \text { level }\end{array}$ & [73] \\
\hline & Fucosterol & $\begin{array}{l}\text { Sargassum } \\
\text { Binderi; } \\
\text { brown alga }\end{array}$ & $\begin{array}{l}3.125,6.25,12.5,25,50 \\
\quad \text { and } 100 \mu \mathrm{g} / \mathrm{mL}\end{array}$ & $\begin{array}{c}\text { Particulate } \\
\text { matter-induced injury } \\
\text { and inflammation in } \\
\text { A549 human lung } \\
\text { epithelial cells }\end{array}$ & $\begin{array}{c}\text { Attenuates oxidative } \\
\text { stress }\end{array}$ & & $\begin{array}{c}\downarrow R O S \text { level } \\
\uparrow S O D, \text { CAT, and } \\
\text { HO- } 1 \text { in the cytosol, } \\
\text { and NRF2 in the } \\
\text { nucleus }\end{array}$ & [74]. \\
\hline & Glycoprotein & U. pinnatifida & $\begin{array}{l}\text { SOD activity and Xox } \\
\text { activity at a } \\
\text { concentration of } \\
5 \mathrm{mg} / \mathrm{mL} \text { and } 1 \mathrm{mg} / \mathrm{mL}, \\
\text { respectively }\end{array}$ & In vitro enzyme assay & & & $\uparrow S O D$ and $\downarrow$ Xox & [75] \\
\hline & Sulfated oligosaccharides & $\begin{array}{l}\text { Ulva lactuca and } \\
\text { Enteromorpha } \\
\text { prolifera; } \\
\text { green algae }\end{array}$ & $150 \mathrm{mg} / \mathrm{kg} \cdot$ day & $\begin{array}{c}\text { Aging model (male } \\
\text { senescence-accelerated } \\
\text { prone (SAMP8) and male } \\
\text { senescence resistant } \\
\text { (SAMR1) mice) }\end{array}$ & Antioxidantion & n.d. & $\begin{array}{c}\uparrow G S H, \text { SOD, CAT, } \\
\text { telomerase levels, } \\
\uparrow \text { Total antioxidant } \\
\text { capacity, } \\
\downarrow \text { MDA and AGEPs }\end{array}$ & [96] \\
\hline
\end{tabular}


Table 1. Cont.

\begin{tabular}{|c|c|c|c|c|c|c|c|c|}
\hline $\begin{array}{l}\text { Pharmacological } \\
\text { Effects }\end{array}$ & Compound (Class) & $\begin{array}{l}\text { Algal Source If } \\
\text { Any) }\end{array}$ & $\begin{array}{c}\text { Effective } \\
\text { Concentration }\end{array}$ & $\begin{array}{c}\text { Experimental Model (In } \\
\text { Vivo/In Vitro) }\end{array}$ & $\begin{array}{c}\text { Cellular } \\
\text { Effects/Significant } \\
\text { Findings }\end{array}$ & $\begin{array}{l}\text { Signaling } \\
\text { Pathways } \\
\text { Involved }\end{array}$ & $\begin{array}{l}\text { Pharmacological } \\
\text { Markers }\end{array}$ & Reference \\
\hline \multirow{5}{*}{$\begin{array}{l}\text { Anti- } \\
\text { inflammatory } \\
\text { activity }\end{array}$} & Fucoxanthin & & 5,10 , and $50 \mu \mathrm{M}$ & $\begin{array}{l}\mathrm{A} \beta_{42} \text {-induced BV2 } \\
\text { microglia cells }\end{array}$ & Anti-inflammation & MAPK pathway & $\begin{array}{c}\downarrow \text { iNOS, COX-2 } \\
\downarrow \text { TNF- } \alpha, \text { IL-6, IL-1 } \beta, \\
\text { PGE }_{2} \\
\downarrow J N K, \text { ERK, and p38 } \\
\text { MAPK } \\
\text { phosphorylation }\end{array}$ & [36] \\
\hline & Fucoxanthin & - & & $\begin{array}{l}\text { LPS-activated BV-2 } \\
\text { microglia }\end{array}$ & $\begin{array}{l}\text { Anti-inflammation } \\
\text { and antioxidation }\end{array}$ & $\begin{array}{c}\text { Akt/NF-kB and } \\
\text { MAPKs/AP-1 } \\
\text { pathways; } \\
\text { PKA/CREB } \\
\text { pathway }\end{array}$ & $\begin{array}{c}\downarrow \text { iNOS, COX-2, } \\
\downarrow \text { TNF- } \alpha, \text { IL-6, PGE } 2, \\
\text { NO, ROS } \\
\downarrow \text { IL-6, TNF- } \alpha, \text { iNOS, } \\
\text { and COX-2 mRNA } \\
\text { expression } \\
\downarrow \text { Akt, NF-kB, ERK, } \\
\text { p38 MAPK and } \\
\text { AP- } 1 \\
\text { phosphorylation } \\
\uparrow \text { Nrf2, HO- } \\
\uparrow \text { PKA, CREB } \\
\uparrow B D N F\end{array}$ & [70] \\
\hline & Fucosterol & U. pinnatifida & 10,25 , or $50 \mu \mathrm{M}$ & $\begin{array}{l}\text { LPS-induced RAW } 264.7 \\
\text { macrophages and THP-1 } \\
\text { human monocyte cell line }\end{array}$ & $\begin{array}{l}\downarrow \text { Inflammatory } \\
\text { response }\end{array}$ & $\begin{array}{l}\downarrow N F-\kappa B \\
\text { pathway }\end{array}$ & $\begin{array}{l}\downarrow \text { iNOS, TNF- } \alpha \text {, and } \\
\text { IL-6 } \\
\downarrow \text { DNA binding } \\
\downarrow \text { phosphorylation } \\
\text { of NF- } \mathrm{kB}, \text { MKK3/6 } \\
\text { and MK2 }\end{array}$ & [83] \\
\hline & Fucosterol & Hizikia fusiformis & $1-10 \mu \mathrm{M}$ & $\begin{array}{l}\mathrm{CoCl}_{2} \text { induced hypoxia } \\
\text { in keratinocytes }\end{array}$ & $\begin{array}{l}\downarrow \text { Inflammatory } \\
\text { response }\end{array}$ & n.d. & $\begin{array}{c}\downarrow \text { IL-6, IL-1 } \beta \text { and } \\
\text { TNF- } \alpha \\
\downarrow \text { pPI3K and pAkt } \\
\text { and HIF1- } \alpha \\
\text { accumulation }\end{array}$ & [82] \\
\hline & Fucosterol & Panida. australis & $0.004,0.2$, and $10 \mu \mathrm{M}$ & $\begin{array}{l}\text { LPS or A } \beta \text {-induced BV2 } \\
\text { (microglial) cells }\end{array}$ & $\begin{array}{c}\text { Protects against LPS } \\
\text { or A } \beta \text {-mediated } \\
\text { neuroinflammation }\end{array}$ & n.d. & $\begin{array}{l}\downarrow \text { IL-6, IL-1 } \beta, \text { TNF- } \alpha, \\
\text { NO, and PGE2 }\end{array}$ & [85] \\
\hline
\end{tabular}


Table 1. Cont.

\begin{tabular}{|c|c|c|c|c|c|c|c|c|}
\hline $\begin{array}{l}\text { Pharmacological } \\
\text { Effects }\end{array}$ & Compound (Class) & $\begin{array}{l}\text { Algal Source If } \\
\text { Any) }\end{array}$ & $\begin{array}{c}\text { Effective } \\
\text { Concentration }\end{array}$ & $\begin{array}{l}\text { Experimental Model (In } \\
\text { Vivo/In Vitro) }\end{array}$ & $\begin{array}{c}\text { Cellular } \\
\text { Effects/Significant } \\
\text { Findings }\end{array}$ & $\begin{array}{l}\text { Signaling } \\
\text { Pathways } \\
\text { Involved }\end{array}$ & $\begin{array}{c}\text { Pharmacological } \\
\text { Markers }\end{array}$ & Reference \\
\hline & Fucosterol & $\begin{array}{l}\text { S. Binderi; } \\
\text { brown alga }\end{array}$ & $\begin{array}{c}3.125,6.25,12.5,25,50 \\
100 \mu \mathrm{g} / \mathrm{mL}\end{array}$ & $\begin{array}{c}\text { Particulate } \\
\text { matter-induced injury } \\
\text { and inflammation in } \\
\text { A549 } \\
\text { human lung epithelial } \\
\text { cells }\end{array}$ & $\begin{array}{l}\downarrow \text { Inflammatory } \\
\text { response }\end{array}$ & n.d. & $\begin{array}{l}\downarrow \text { COX-2, PGE2, } \\
\text { TNF- } \alpha \text { and IL-6 }\end{array}$ & [74] \\
\hline & Dieckol (phlorotannin) & E. cava & $50-300 \mu \mathrm{g} / \mathrm{mL}$ & $\begin{array}{l}\text { LPS-stimulated murine } \\
\text { BV2 microglia }\end{array}$ & $\begin{array}{l}\text { Anti-inflammation } \\
\text { and antioxidation }\end{array}$ & $\begin{array}{c}\text { p-38 MAPK/ } \\
\text { NF-kB pathway }\end{array}$ & $\begin{array}{c}\downarrow \mathrm{NO} \text { and } \mathrm{PGE}_{2} ; \\
\downarrow \mathrm{NNOS} \text { and COX-2; } \\
\downarrow \mathrm{IL}-1 \beta \text { and TNF- } \alpha ; \\
\quad \downarrow \text { ROS }\end{array}$ & [86] \\
\hline & $\begin{array}{c}\text { Phloroglucinol, eckol, } \\
\text { dieckol, 7-phloroeckol, } \\
\text { phlorofucofuroeckol A } \\
\text { and dioxinodehydroeckol } \\
\text { (phlorotannin) }\end{array}$ & $\begin{array}{l}\text { E. bicyclis; } \\
\text { brown alga }\end{array}$ & 5-20 $\mu \mathrm{M}$ for $\mathrm{NO}$ & $\begin{array}{l}\text { LPS-stimulated RAW } \\
264.7 \text { murine } \\
\text { macrophages }\end{array}$ & $\begin{array}{l}\downarrow I \text { Inflammatory } \\
\text { response }\end{array}$ & $\begin{array}{l}\downarrow N F-k B \\
\text { pathway }\end{array}$ & $\downarrow N O$ production & [72] \\
\hline & Phlorofucofuroeckol A & E. stolonifera & $20 \mu \mathrm{M}$ & $\begin{array}{l}\text { LPS-activated BV2 and } \\
\text { primary microglial cells }\end{array}$ & Anti-inflammation & $\begin{array}{l}\text { NF-kB, JNKs, } \\
\text { p38 MAPK, and } \\
\text { Akt pathways }\end{array}$ & $\begin{array}{c}\downarrow N \mathrm{NO} \text { and } \mathrm{PGE}_{2} ; \\
\downarrow \mathrm{NNOS} \text { and COX-2; } \\
\downarrow \mathrm{IL}-1 \beta, \mathrm{IL}-6 \text { and } \\
\text { TNF- } \alpha \\
\downarrow \text { NF- } \mathrm{kB} \text { activation } \\
\text { and IKB- } \alpha \\
\text { degradation } \\
\downarrow \mathrm{NNK}, \mathrm{p} 38 \text {, and Akt }\end{array}$ & [87] \\
\hline & $\begin{array}{l}\text { Phlorofucofuroeckol B } \\
\text { (phlorotannin) }\end{array}$ & E. stolonifera & $10-40 \mu \mathrm{M}$ & $\begin{array}{l}\text { LPS-stimulated murine } \\
\text { BV2 microglia }\end{array}$ & Anti-inflammation & $\begin{array}{c}\text { I } \kappa-\alpha / N F-\kappa B \\
\text { and } \\
\text { Akt/ERK/JNK } \\
\text { pathways }\end{array}$ & $\begin{array}{c}\downarrow \text { TNF- } \alpha, \text { IL- } 1 \beta \text { and } \\
\text { IL-6; } \\
\downarrow \text { COX-2 and iNOS } \\
\downarrow \text { NF- } \mathrm{kB} \text { activation } \\
\text { and IKB- } \alpha \\
\text { degradation } \\
\downarrow \text { Akt, ERK, and JNK } \\
\text { phosphorylation }\end{array}$ & [88] \\
\hline & $\begin{array}{c}\text { 8,8'-bieckol } \\
\text { (phlorotannin) }\end{array}$ & E. cava & & $\begin{array}{c}\text { LPS-stimulated primary } \\
\text { macrophages and RAW } \\
264.7 \text { macrophages } \\
\& \\
\text { LPS-induced septic mice }\end{array}$ & $\begin{array}{l}\text { Anti-inflammation; } \\
\text { Protects mice from } \\
\text { endotoxin shock }\end{array}$ & NF-kB pathway & $\begin{array}{c}\downarrow N \mathrm{NO} \text { and } \mathrm{PGE}_{2} ; \\
\downarrow \mathrm{NNOS} \text { mRNA and } \\
\text { protein expression; } \\
\downarrow I L-6 ; \\
\downarrow \text { Transactivation of } \\
\text { NF- } \mathrm{kB} \text { and nuclear } \\
\text { translocation of the } \\
\text { NF- } \mathrm{kB} \text { p65 subunit } \\
\downarrow \text { ROS }\end{array}$ & [90] \\
\hline
\end{tabular}


Table 1. Cont.

\begin{tabular}{|c|c|c|c|c|c|c|c|c|}
\hline $\begin{array}{l}\text { Pharmacological } \\
\text { Effects }\end{array}$ & Compound (Class) & $\begin{array}{l}\text { Algal Source If } \\
\text { Any) }\end{array}$ & $\begin{array}{c}\text { Effective } \\
\text { Concentration }\end{array}$ & $\begin{array}{c}\text { Experimental Model (In } \\
\text { Vivo/In Vitro) }\end{array}$ & $\begin{array}{c}\text { Cellular } \\
\text { Effects/Significant } \\
\text { Findings }\end{array}$ & $\begin{array}{l}\text { Signaling } \\
\text { Pathways } \\
\text { Involved }\end{array}$ & $\begin{array}{l}\text { Pharmacological } \\
\text { Markers }\end{array}$ & Reference \\
\hline & $\begin{array}{c}\text { 6,6'-bieckol } \\
\text { (phlorotannin) }\end{array}$ & E.stolonifera & & $\begin{array}{l}\text { LPS-stimulated BV2 and } \\
\text { murine primary } \\
\text { microglial cells }\end{array}$ & Anti-inflammation & $\begin{array}{l}\text { I } \kappa \text { B- } \alpha / \mathrm{NF}-\kappa \mathrm{B} \\
\text { and JNK/p38 } \\
\text { MAPK/Akt } \\
\text { pathways }\end{array}$ & $\begin{array}{c}\downarrow \text { CCOX-2 and iNOS; } \\
\downarrow \text { NO and PGE } \\
\downarrow \text { IL-6 } \\
\downarrow \text { Transactivation of } \\
\text { NF-kB and nuclear } \\
\text { translocation of the } \\
\text { NF-kB p65 subunit } \\
\downarrow \text { Akt, JNK and p38 } \\
\text { MAPK } \\
\text { phosphorylation }\end{array}$ & [89] \\
\hline & $\begin{array}{l}\text { Fucoidan (sulfated } \\
\text { polysaccharide) }\end{array}$ & Brown seaweed & 25,50 , and $100 \mu \mathrm{g} / \mathrm{mL}$ & $\begin{array}{l}\text { LPS-stimulated murine } \\
\text { BV2 microglia }\end{array}$ & Anti-inflammation & $\begin{array}{l}\text { NF-kB and } \\
\text { JNK/p38 } \\
\text { MAPK/Akt } \\
\text { pathways }\end{array}$ & $\begin{array}{c}\downarrow \mathrm{NO}^{2} \text { and } \mathrm{PGE}_{2} ; \\
\downarrow \mathrm{COX}-2, \text { iNOS and } \\
\text { MCP-1; } \\
\downarrow \text { TNF- } \alpha \text { and IL-1 } ; \\
\downarrow \text { NF- } \mathrm{BB} \text { activation; } \\
\downarrow \text { Akt, ERK, p38 } \\
\text { MAPK and JNK } \\
\text { phosphorylation }\end{array}$ & [92] \\
\hline & Fucoidan & - & $125 \mu \mathrm{g} / \mathrm{mL}$ & $\begin{array}{c}\text { LPS-activated primary } \\
\text { microglia }\end{array}$ & Anti-inflammation & n.d. & $\downarrow \mathrm{TNF}-\alpha$ and ROS & [93] \\
\hline & $\begin{array}{c}\text { K-carrageenan } \\
\text { oligosaccharides and } \\
\text { desulfated derivatives }\end{array}$ & Red algae & & LPS-activated microglia & Anti-inflammation & n.d. & $\downarrow$ TNF- $\alpha$ & [94] \\
\hline & Sulfated oligosaccharides & $\begin{array}{l}\text { U. lactuca and } E \text {. } \\
\text { prolifera; } \\
\text { green algae }\end{array}$ & $150 \mathrm{mg} / \mathrm{kg} \cdot$ day & $\begin{array}{c}\text { Aging model (male } \\
\text { senescence-accelerated } \\
\text { prone (SAMP8) and male } \\
\text { senescence resistant } \\
\text { (SAMR1) mice) }\end{array}$ & $\begin{array}{l}\downarrow I \text { Inflammatory } \\
\text { response }\end{array}$ & n.d. & $\begin{array}{c}\downarrow \mathrm{IFN}-\gamma \text {, TNF- } \alpha \text {, and } \\
\text { IL-6 }\end{array}$ & [96] \\
\hline & $\begin{array}{l}\text { Alginate-derived } \\
\text { oligosaccharide }\end{array}$ & Brown algae & $50-500 \mu \mathrm{g} / \mathrm{mL}$ & $\begin{array}{c}\text { LPS/A } \beta \text {-stimulated BV2 } \\
\text { microglia }\end{array}$ & Anti-inflammation & $\begin{array}{l}\text { TLR4/NF-kB } \\
\text { signaling } \\
\text { pathway }\end{array}$ & $\begin{array}{c}\downarrow \mathrm{NOO} \text { and } \mathrm{PGE}_{2} ; \\
\downarrow \mathrm{COX}-2 \text { and iNOS; } \\
\downarrow \mathrm{TNF}-\alpha, \text { IL-6 and } \\
\text { IL-12; } \\
\downarrow \mathrm{TLR} 4 \\
\uparrow \mathrm{NF} \text { - } \mathrm{B} / \mathrm{p} 65 \text { subunit } \\
\text { translocation }\end{array}$ & [97] \\
\hline
\end{tabular}


Table 1. Cont.

\begin{tabular}{|c|c|c|c|c|c|c|c|c|}
\hline $\begin{array}{l}\text { Pharmacological } \\
\text { Effects }\end{array}$ & Compound (Class) & $\begin{array}{l}\text { Algal Source If } \\
\text { Any) }\end{array}$ & $\begin{array}{c}\text { Effective } \\
\text { Concentration }\end{array}$ & $\begin{array}{c}\text { Experimental Model (In } \\
\text { Vivo/In Vitro) }\end{array}$ & $\begin{array}{c}\text { Cellular } \\
\text { Effects/Significant } \\
\text { Findings } \\
\end{array}$ & $\begin{array}{l}\text { Signaling } \\
\text { Pathways } \\
\text { Involved }\end{array}$ & $\begin{array}{l}\text { Pharmacological } \\
\text { Markers }\end{array}$ & Reference \\
\hline & Seleno-polymannuronate & Brown algae & $0.8 \mathrm{mg} / \mathrm{mL}$ & $\begin{array}{l}\text { LPS-activated primary } \\
\text { microglia and astrocytes; } \\
\text { mouse model of acute } \\
\text { inflammation }\end{array}$ & Anti-inflammation & $\begin{array}{l}\text { NF-kB and } \\
\text { MAPK signaling }\end{array}$ & $\begin{array}{c}\downarrow N O \text { and } \text { PGE }_{2} ; \\
\downarrow C O X-2 \text { and iNOS; } \\
\downarrow \text { TNF- } \alpha, \text { IL-1 } 1 \beta \text { and } \\
\text { IL-6; } \\
\uparrow I \kappa B-\alpha, \text { p65, p38, } \\
\text { ERK and JNK } \\
\text { phosphorylation }\end{array}$ & [98] \\
\hline & $\begin{array}{c}\text { Sargaquinoic acid } \\
\text { (plastoquinone) }\end{array}$ & $\begin{array}{l}\text { Sargassum } \\
\text { siliquastrum }\end{array}$ & & $\begin{array}{l}\text { LPS-stimulated RAW } \\
264.7 \text { macrophages }\end{array}$ & Anti-inflammation & NF-кB signaling & $\begin{array}{c}\downarrow \mathrm{NO} ; \downarrow \text { iNOS; } \\
\uparrow \mathrm{I} \mathrm{B}-\alpha ; \downarrow \text { nuclear } \\
\text { translocation of } \\
\text { NF-kB; } \\
\downarrow J \mathrm{NK} 1 / 2 \text { MAPK } \\
\end{array}$ & [100] \\
\hline & $\begin{array}{l}\text { Floridoside (glycerol } \\
\text { glycosides) }\end{array}$ & $\begin{array}{l}\text { Laurencia } \\
\text { undulate; } \\
\text { red alga }\end{array}$ & $50 \mu \mathrm{M}$ & $\begin{array}{l}\text { LPS-stimulated murine } \\
\text { BV2 microglia }\end{array}$ & Anti-inflammation & $\begin{array}{l}\text { MAPK } \\
\text { Signaling }\end{array}$ & $\begin{array}{c}\downarrow \text { NO, ROS; } \\
\text { \NOS and COX-2; } \\
\downarrow \text { p38 MAPK and } \\
\text { ERK } \\
\text { phosphorylation }\end{array}$ & [101] \\
\hline & Glycoprotein & U. pinnatifida & $\begin{array}{c}\text { COX-1 and COX-2 } \\
\text { inhibition with IC } \mathrm{I}_{50} \\
\quad \text { values of } \\
53.03 \pm 1.03 \mu \mathrm{g} / \mathrm{mL} \text { and } \\
\begin{array}{c}193.35 \pm 3.08 \mu \mathrm{g} / \mathrm{mL} \\
\text { respectively }\end{array}\end{array}$ & $\begin{array}{l}\text { LPS-stimulated RAW } \\
264.7 \text { macrophages }\end{array}$ & Anti-inflammation & n.d. & $\begin{array}{c}\downarrow \mathrm{COX}-1 \text { and COX-2 } \\
\downarrow \text { NO }\end{array}$ & [75] \\
\hline & $\begin{array}{l}\text { Caulerpin (bisindole } \\
\text { alkaloid) }\end{array}$ & $\begin{array}{l}\text { Caulerpa } \\
\text { racemosa }\end{array}$ & $100 \mu \mathrm{M} / \mathrm{kg}$ body wt & $\begin{array}{l}\text { Capsaicin-induced ear } \\
\text { edema and } \\
\text { carrageenan-induced } \\
\text { peritonitis }\end{array}$ & $\begin{array}{l}\text { Inhibition of } \\
\text { nociception }\end{array}$ & n.d. & n.d. & [130] \\
\hline & $\begin{array}{l}\text { Caulerpenyne } \\
\text { (sesquiterpene) }\end{array}$ & $\begin{array}{l}\text { C. prolifera and } \\
\text { C. racemosa }\end{array}$ & $5.1 \mu \mathrm{M}$ & $\begin{array}{l}\text { Lipoxygenase (LOX) } \\
\text { enzyme activity assay }\end{array}$ & $\begin{array}{l}\text { Inhibitory activity } \\
\text { against LOX }\end{array}$ & - & $\begin{array}{l}\text { Un-competitive } \\
\text { type of inhibition }\end{array}$ & [131] \\
\hline
\end{tabular}


Table 1. Cont.

\begin{tabular}{|c|c|c|c|c|c|c|c|c|}
\hline $\begin{array}{l}\text { Pharmacological } \\
\text { Effects }\end{array}$ & Compound (Class) & $\begin{array}{l}\text { Algal Source If } \\
\text { Any) }\end{array}$ & $\begin{array}{c}\text { Effective } \\
\text { Concentration }\end{array}$ & $\begin{array}{l}\text { Experimental Model (In } \\
\text { Vivo/In Vitro) }\end{array}$ & $\begin{array}{c}\text { Cellular } \\
\text { Effects/Significant } \\
\text { Findings }\end{array}$ & $\begin{array}{l}\text { Signaling } \\
\text { Pathways } \\
\text { Involved }\end{array}$ & $\begin{array}{c}\text { Pharmacological } \\
\text { Markers }\end{array}$ & Reference \\
\hline & $\begin{array}{l}\text { Aquamin (multi-mineral } \\
\text { complex) }\end{array}$ & $\begin{array}{c}\text { Lithothamnion } \\
\text { corallioides; red } \\
\text { alga }\end{array}$ & & $\begin{array}{l}\text { LPS-stimulated, } \\
\text { glial-enriched primary } \\
\text { cultures of rat cortex }\end{array}$ & Anti-inflammation & n.d. & $\downarrow$ TNF- $\alpha$ and IL-1 $\beta$ & [132] \\
\hline \multirow{9}{*}{$\begin{array}{c}\text { Anticholinesterase } \\
\text { activity }\end{array}$} & $\begin{array}{c}\text { Fucosterol and } \\
\text { 24-hydroperoxy } \\
\text { 24-vinylcholesterol }\end{array}$ & E. stolonifera & $\begin{array}{c}\mathrm{IC}_{50} \text { values of } 421.72 \pm \\
1.43,176.46 \pm 2.51 \mu \mathrm{M} \\
\text { respectively }\end{array}$ & In vitro enzymatic assay & $\downarrow B C h E$ activity & - & $\begin{array}{l}\text { Selective inhibition } \\
\text { of BChE }\end{array}$ & [114] \\
\hline & Fucosterol & Panida australis & $\begin{array}{c}\text { inhibition against } \\
\text { AChE }(10.99-20.71 \%) \\
\text { and BChE }(4.53-17.53 \%) \\
\text { with concentrations } \leq \\
56 \mu \mathrm{M},\end{array}$ & In vitro enzymatic assay & $\begin{array}{c}\downarrow \mathrm{AChE} \text { and } \mathrm{BChE} \\
\text { activities }\end{array}$ & - & $\begin{array}{l}\text { Nonselective } \\
\text { cholinesterase } \\
\text { inhibition }\end{array}$ & [85] \\
\hline & Fucosterol & $\begin{array}{l}\text { Sargassum } \\
\text { horridum }\end{array}$ & - & In vitro enzymatic assay & $\downarrow \mathrm{AChE}$ activity & - & $\begin{array}{l}\text { Non-competitive } \\
\text { inhibition }\end{array}$ & [115] \\
\hline & Fucoxanthin & - & $\mathrm{IC}_{50}$ value $1.97 \mathrm{mM}$ & $\begin{array}{l}\text { In vitro } \mathrm{BChE} \text { activity } \\
\text { assay }\end{array}$ & $\downarrow B C h E$ activity & & $\begin{array}{l}\text { Mixed inhibition } \\
\text { type }\end{array}$ & [116]. \\
\hline & Fucoxanthin & Brown seaweed & IC50 value of $81.2 \mu \mathrm{M}$ & $\begin{array}{c}\text { In vitro AChE activity } \\
\text { assay; } \\
\text { Molecular docking } \\
\text { analysis }\end{array}$ & $\downarrow$ AChE activity & $\begin{array}{c}\text { Fucoxanthin } \\
\text { likely interacts } \\
\text { with the } \\
\text { peripheral } \\
\text { anionic site } \\
\text { within AChE }\end{array}$ & $\begin{array}{l}\text { Non-competitive } \\
\text { manner }\end{array}$ & [117] \\
\hline & $\alpha$-Bisabolol & $\begin{array}{c}\text { Padina } \\
\text { gymnospora }\end{array}$ & IC50 value $<10 \mu \mathrm{g} / \mathrm{mL}$ & In vitro enzymatic assay & $\begin{array}{c}\downarrow \mathrm{AChE} \text { and } \mathrm{BChE} \\
\text { activity }\end{array}$ & - & - & [118] \\
\hline & Glycoprotein & U. pinnatifida & $\begin{array}{c}\text { AChE and BChE } \\
\text { inhibitory activities } \\
\text { with IC } 50 \text { values of } \\
63.56 \pm 1.86 \text { and } 99.03 \pm \\
4.64 \text {, respectively }\end{array}$ & In vitro enzymatic assay & $\begin{array}{c}\downarrow \mathrm{AChE} \text { and } \mathrm{BChE} \\
\text { activity }\end{array}$ & - & - & [75] \\
\hline & $\begin{array}{c}\text { Phloroglucinol, } \\
\text { dibenzo [1,4] } \\
\text { dioxine-2,4,7,9-tetraol } \\
\text { and eckol }\end{array}$ & $\begin{array}{l}\text { Ecklonia maxima; } \\
\text { Brown alga }\end{array}$ & $\begin{array}{l}\text { IC50 value: } 76.70 \text { to } \\
579.32 \mu \mathrm{M}\end{array}$ & $\begin{array}{c}\text { In vitro AChE activity } \\
\text { assay }\end{array}$ & $\downarrow \mathrm{AChE}$ activity & - & - & [119] \\
\hline & $\begin{array}{c}\text { Dieckol and } \\
\text { phlorofucofuroeckol }\end{array}$ & E. cava & & $\begin{array}{l}\text { Ethanol-intoxicated } \\
\text { memory impairment in } \\
\text { mice }\end{array}$ & $\downarrow$ AChE activity & n.d. & $\uparrow$ Acetylcholine & [120] \\
\hline
\end{tabular}


Table 1. Cont.

\begin{tabular}{|c|c|c|c|c|c|c|c|c|}
\hline $\begin{array}{l}\text { Pharmacological } \\
\text { Effects }\end{array}$ & Compound (Class) & $\begin{array}{l}\text { Algal Source If } \\
\text { Any) }\end{array}$ & $\begin{array}{c}\text { Effective } \\
\text { Concentration }\end{array}$ & $\begin{array}{l}\text { Experimental Model (In } \\
\text { Vivo/In Vitro) }\end{array}$ & $\begin{array}{c}\text { Cellular } \\
\text { Effects/Significant } \\
\text { Findings }\end{array}$ & $\begin{array}{l}\text { Signaling } \\
\text { Pathways } \\
\text { Involved }\end{array}$ & $\begin{array}{l}\text { Pharmacological } \\
\text { Markers }\end{array}$ & Reference \\
\hline & $\begin{array}{l}\text { Sargaquinoic acid and } \\
\text { sargachromenol } \\
\text { (plastoquinones) }\end{array}$ & $\begin{array}{l}\text { Sargassum } \\
\text { sagamianum }\end{array}$ & $\begin{array}{c}\mathrm{IC}_{50} \text { value for } \\
\text { anti-AChE: } 23.2 \text { and } \\
32.7 \mu \mathrm{M} \text {, respectively; } \\
\mathrm{IC}_{50} \text { value for } \\
\text { anti-BChE of } \\
\text { sargaquinoic acid } \\
26 \mathrm{~nm}\end{array}$ & $\begin{array}{c}\text { In vitro } \mathrm{ChE} \text { activity } \\
\text { assay }\end{array}$ & $\begin{array}{l}\text { Sargaquinoic acid } \\
\text { shows potent } \\
\text { inhibitory activity } \\
\text { against BuChE and } \\
\text { moderate inhibitory } \\
\text { activity against AChE }\end{array}$ & - & - & [121] \\
\hline & $\begin{array}{c}\text { (5E,10Z)-6,10,14- } \\
\text { trimethylpentadeca } \\
-5,10 \text {-dien-2, 12-dione and } \\
(5 E, 9 E, 13 E)-6 \\
\text { 10,14-trimethylpentadeca } \\
\text {-5,9,13-trien-2,12-dione } \\
\text { (Sesquiterpenes) }\end{array}$ & S. sagamianum & $\begin{array}{c}\mathrm{IC}_{50} \text { values of } 65.0 \text { and } \\
48.0 \text {, and } 34.0 \text { and } \\
23.0 \mu \mathrm{M} \text {, respectively }\end{array}$ & $\begin{array}{c}\text { In vitro ChE activity } \\
\text { assay }\end{array}$ & $\begin{array}{l}\text { Moderate inhibitory } \\
\text { activity against AChE } \\
\text { and BuChE }\end{array}$ & - & - & [133] \\
\hline \multirow{5}{*}{$\begin{array}{c}\text { Anti- } \\
\text { amyloidogenic } \\
\text { and aggregation } \\
\text { inhibition } \\
\text { activity }\end{array}$} & Fucoxanthin & $\begin{array}{l}\text { E. stolonifera and } \\
\text { U. pinnatifida }\end{array}$ & & & $\begin{array}{c}\downarrow \beta \text {-secretase activity; } \\
\text { Binding energy } \\
(-7.0 \mathrm{kcal} / \mathrm{mol})\end{array}$ & - & $\begin{array}{l}\text { mixed-type } \\
\text { inhibition }\end{array}$ & [134] \\
\hline & Fucoxanthin & - & $0.1-30 \mu \mathrm{M}$ & & $\begin{array}{l}\text { Suppresses the } \\
\text { formation of } A \beta 1-42 \\
\text { fibrils and } A \beta 1-42 \\
\text { oligomers, and } \\
\text { inhibits } A \beta \\
\text { aggregation }\end{array}$ & - & - & [135] \\
\hline & Fucoxanthin & - & $2 \mu \mathrm{M}$ & ThT assay & $\begin{array}{l}\text { Inhibits A } \beta 1-42 \text { fibril } \\
\text { and aggregate } \\
\text { formation }\end{array}$ & - & - & [136] \\
\hline & Fucosterol & $\begin{array}{l}\text { E. stolonifera and } \\
\text { U. pinnatifida }\end{array}$ & $\begin{array}{l}10-100 \mu \mathrm{M}\left(\mathrm{IC}_{50} \text { value }\right. \\
\text { of } 64.12 \pm 1.0 \mu \mathrm{M})\end{array}$ & $\begin{array}{l}\text { In vitro enzyme assay; } \\
\text { In silico analysis }\end{array}$ & $\begin{array}{c}\downarrow \beta \text {-secretase activity; } \\
\text { Binding energy } \\
(-10.1 \mathrm{kcal} / \mathrm{mol})\end{array}$ & - & $\begin{array}{l}\text { Noncompetitive } \\
\text { inhibition }\end{array}$ & [134] \\
\hline & $\alpha$-Bisabolol & $\begin{array}{c}\text { Padina } \\
\text { gymnospora }\end{array}$ & $5 \mu \mathrm{g} / \mathrm{mL}$ & $\begin{array}{c}\text { Thioflavin T (ThT), } \\
\text { Confocal laser scanning } \\
\text { microscopy (CLSM) } \\
\text { analysis, Transmission } \\
\text { electron microscopy } \\
\text { (TEM), Fourier transform } \\
\text { infrared (FTIR) } \\
\text { spectroscopic analysis } \\
\text { and molecular dynamics } \\
\text { simulation }\end{array}$ & $\begin{array}{l}\text { Prevents oligomers } \\
\text { formation as well as } \\
\text { disaggregates the } \\
\text { matured fibrils }\end{array}$ & - & - & [137] \\
\hline
\end{tabular}


Table 1. Cont

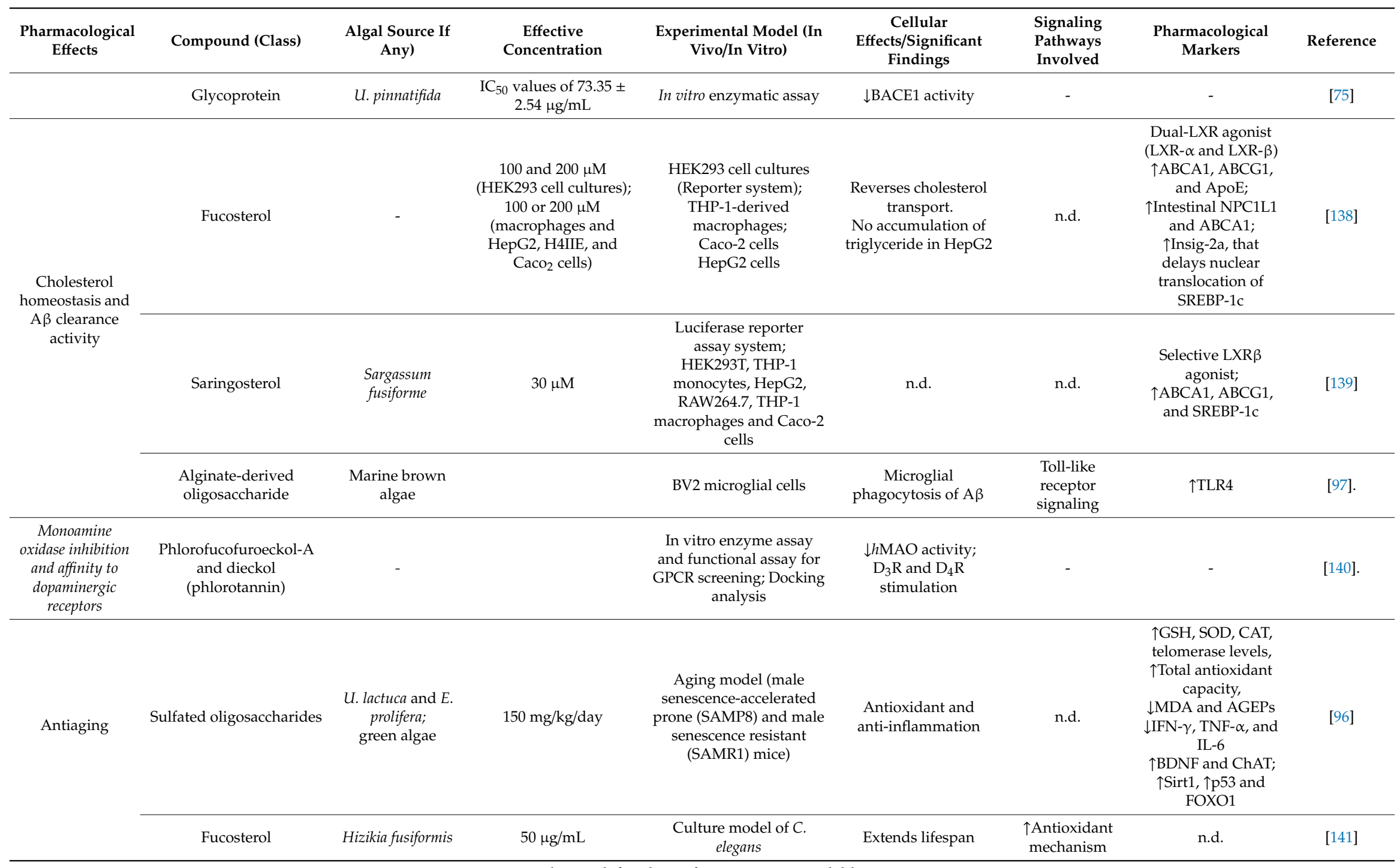

n.d.: not defined; -: information not available. 


\subsection{Anti-Amyloidogenic and Aggregation Inhibition Activity}

As amyloid- $\beta$ deposition is one of the hallmarks of $A D$, compounds that interfere with the generation of pathogenic $A \beta$ and/or that inhibit its aggregation are of therapeutic importance. Several metabolites of marine algae have shown anti-amyloidogenic potentials (Table 1). For example, fucoxanthin at variant concentrations reduced the formation of $A \beta_{1-42}$ fibril and $A \beta 1-42$ oligomers, when co-incubated with $A \beta_{1-42}$ monomers $[135,136]$. Both studies also demonstrated that fucoxanthin has been shown to inhibit $A \beta$ aggregation $[135,136]$. Inhibition of $\beta$-site amyloid precursor protein cleaving enzyme 1 (BACE1) with fucoxanthin was of a mixed-type [134]. In addition, molecular docking analysis revealed a differential pattern of interaction [134]. Fucosterol showed a potential anti-BACE1 activity, which was a noncompetitive type [134]. Supporting these findings, a recent in silico study also explained the binding and interaction pattern of fucosterol with BACE1 [142]. $\alpha$-Bisabolol from Padina gymnospora prevented oligomers formation as well as disaggregated the matured fibrils [118]. Glycoprotein from $U$. pinnatifida exhibited anti-BACE1 activities with $\mathrm{IC}_{50}$ values of $73.35 \pm 2.54 \mu \mathrm{g} / \mathrm{mL}$ [75]. Meroterpenoids, such as sargahydroquinoic acid, sargachromenol, and sargaquinoic acid of S. serratifolium, exhibited potent anti-BACE1 activity [123]. Phlorotannins, such as eckol, dieckol, and 8,8'-bieckol from Ecklonia cava showed anti-BACE1 activity [124]. Olasehinde et al. reported that four South African macroalgae such as Gracilaria gracilis, Ulva lactuca, Ecklonia maxima, and Gelidium pristoides exhibited anti-cholinesterase, anti-BACE1, and A $\beta$ aggregation inhibitory activities, indicating that these types of seaweed could be potential sources of anti-AD agents [35]. Ishige foliacea extract showed $\beta$-secretase inhibition property [128].

\subsection{Cholesterol Homeostasis and A $\beta$ Clearance Activity}

Some algal metabolites are known to activate LXR- $\beta$ (Table 1), and thus help regulate cholesterol homeostasis and enhance $\mathrm{A} \beta$ clearance [56]. Fucosterol is a selective LXR- $\beta$ agonist that upregulated several LXR target genes, such as ATP-binding cassette transporter A1 (ABCA1), ABCG1, and apolipoprotein $E(A p o E)[138,139]$, suggesting that fucosterol could play a significant role in brain cholesterol homeostasis. Saringasterol, another selective LXR- $\beta$ agonist isolated from $S$. fusiforme, activated the expression of similar LXR target genes in multiple cell lines [139]. Alginate-derived oligosaccharide isolated from marine brown algae promoted the microglial phagocytosis of $A \beta$, which is connected to the activation of toll-like receptor signaling [97]. As cholesterol imbalance and impaired protein clearance system significantly contribute to the pathogenesis of major neurological disorders, more efforts should, therefore, be paid to explore similar compounds that may help regulate cholesterol homeostasis and proteostasis.

\subsection{Monoamine Oxidase Inhibition and Affinity to Dopaminergic Receptors}

Inhibition of MAO-A (monoamine oxidase-A), an enzyme that catalyzes oxidative deamination of neuroamines, such as dopamine, norepinephrine, and serotonin (5-HT), is a putative approach to raise the brain 5-HT level, thus alleviating the symptoms of Parkinsonism [143]. Seong and team screened the multi-target effects of three phlorotannins, i.e., phloroglucinol, phlorofucofuroeckol-A (PFF-A), and dieckol against human MAO-A and -B and various neuronal G-protein-coupled receptors (GPCRs). Of these, PFF-A exhibited a relatively higher inhibition against both $h \mathrm{MAO}$ isoforms, with greater selectivity toward $h \mathrm{MAO}-\mathrm{B}$ (Table 1). Enzyme kinetics and computational findings indicated that PFF-A noncompetitively interacted with $h \mathrm{MAOs}$ and acted allosterically. In a functional assay for GPCR screening, dieckol and PFF-A showed a multi-target combination of $\mathrm{D}_{3} \mathrm{R} / \mathrm{D}_{4} \mathrm{R}$ agonism and $\mathrm{D}_{1} / 5 \mathrm{HT}_{1 \mathrm{~A}} / \mathrm{NK}_{1}$ antagonism [140]. 


\subsection{Anti-Aging}

Algal compounds that exhibited anti-aging effects (Table 1) could have therapeutic value for physiological as well as pathological brain aging. Sulfated oligosaccharides of Ulva lactuca and Enteromorpha prolifera, when treated in SAMP8 mice, increased the serum level of antioxidant molecules and total antioxidant capacity, and decreased the levels of malondialdehyde (MDA) and advanced glycation end products in the serum of experimental mice [96]. It has also been observed that these oligosaccharides decreased inflammatory factors, increased BDNF and choline acetyltransferase (ChAT) levels, and promoted the survival of hippocampal neurons. The underlying mechanisms involved the downregulation of $p 53$ and FOXO1 genes and the upregulation of Sirt1 gene [96]. Caenorhabditis elegans, when treated with fucosterol (at $50 \mu \mathrm{g} / \mathrm{mL}$ ), survived longer compared to control, indicating that this algal compound might help extend life-span and thus might protect against premature aging [141]. Antioxidant, anti-inflammatory, and immunostimulatory properties of fucosterol were supposed to be involved in its pro-survival effect [144].

\subsection{Neurotrophic Activity}

Compounds with neuritogenic potentials are promising to reconstruct a damaged neuronal network, which is a characteristic feature of neurodegeneration. Several algal metabolites have shown a promising neurite outgrowth promoting potentials in cell culture conditions (Table 2). Sargachromenol from Sargassum macrocarpum promoted nerve growth factor (NGF)-dependent neuronal differentiation of PC12D cells by activating cyclic AMP-mediated protein kinase and MAPK1/2 and supported their survival by activating phosphatidylinositol-3 kinase (PI3K) [145]. Sargaquinoic acid, another metabolite from S. macrocarpum, promoted neuritogenesis in PC12D cells, which involved cooperation between two independent pathways, i.e., the TrkA-MAPK pathway and adenylate cyclase-PKA pathway [146]. Ina and colleagues demonstrated that the neurodifferentiation of PC12 cells by pheophytin a of Sargassum fulvellum required the presence of NGF and involved the activation of an MAPK signaling pathway [147]. Vitamin $\mathrm{B}_{12}$, a chlorophyll-related analog to pheophytin a, also stimulated NGF-dependent PC12 cell differentiation by an MAPK signaling pathway [148].

Dimethylsulfoniopropionate (DMSP) promoted neurite outgrowth and protected against TDA-induced cytotoxicity, involving the upregulation of Hsp32 and activation of the extracellular signal-regulated kinases 1/2 (ERK1/2) [149]. Fucoxanthin has shown to exhibit neurite outgrowth activity (15.7-31\% of cells to develop neurite outgrowth) at much lower concentrations $(0.1-2 \mu \mathrm{M})$, in the absence of NGF support, indicating that this marine carotenoid could a potential neurotrophic molecule [136]. Gracilariopsis chorda and its active compound arachidonic acid modulated spine dynamics, and potentiated functional synaptic plasticity of hippocampal neurons [150].

In addition, several marine algae have shown to promote neurite outgrowth. For example, Sargassum macrocarpum and Jania adharens showed neuritogenic potentials and promoted neuron-specific dendrites and axons from PC12D cells [151]. Two compounds, namely sargachromenol [145] and sargaquinoic acid [148], having neurite outgrowth potential were already isolated. Porphyra yezoensis and its compound taurine facilitated neuronal development and maturation of primary hippocampal neurons [152]. Gelidium amansii [153-156], Sargassum fulvellum [157], Undaria pinnatifida and Saccharina japonica [158], Gracilariopsis chorda [150,159], and carrageenophyte Kappaphycus alvarezii [160-163] promoted neuronal morphology and functions. Of these, G. amansii that exhibited neuromodulatory potentials in several studies [153-156] could be the most promising candidate for further isolation of neurotrophic agents and thus expects special attention of natural product chemists. 
Table 2. Neurotrophic activity of algal phytochemicals in vitro.

\begin{tabular}{|c|c|c|c|c|c|c|}
\hline Compound & Algal Origin (If Any) & Dosage & $\begin{array}{l}\text { Experimental Model } \\
\text { (In Vivo/In Vitro) }\end{array}$ & $\begin{array}{c}\text { Cellular Effects/Significant } \\
\text { Findings }\end{array}$ & $\begin{array}{l}\text { Pharmacological } \\
\text { Markers }\end{array}$ & References \\
\hline Sargachromenol & $\begin{array}{c}\text { Sargassum } \\
\text { macrocarpum } \\
\text { (Brown alga, Japan) }\end{array}$ & $\begin{array}{l}\mathrm{ED}_{50} 9 \mu \mathrm{M} \text { (with } \\
10 \mathrm{ng} / \mathrm{mL} \text { NGF) }\end{array}$ & PC12D cells & $\begin{array}{l}\text { NGF-dependent neurite } \\
\text { outgrowth and survival }\end{array}$ & $\begin{array}{c}\uparrow \mathrm{PKA} \text { and MAPK } 1 / 2 \\
\uparrow \mathrm{PI} 3 \mathrm{~K}\end{array}$ & [145] \\
\hline Sargaquinoic acid & $\begin{array}{l}\text { S. macrocarpum } \\
\text { (Brown alga, Japan) }\end{array}$ & $\begin{array}{c}3 \mu \mathrm{gg} / \mathrm{mL} \text { (with } \\
10 \mathrm{ng} / \mathrm{mL} \text { NGF) }\end{array}$ & & Cell differentiation & $\begin{array}{c}\text { Protein Kinase A and } \\
\text { MAP } \\
\text { Kinases-Mediated } \\
\text { Signaling Pathways }\end{array}$ & [146] \\
\hline $\begin{array}{c}\text { Vitamin B12 } \\
\text { (chlorophyll-related analog to } \\
\text { pheophytin) }\end{array}$ & $\begin{array}{l}\text { Sargassum fulvellum } \\
\text { (Brown alga, Japan) }\end{array}$ & & PC12 cells & Cell differentiation & $\begin{array}{l}\text { MAPK signal } \\
\text { transduction pathway }\end{array}$ & [148] \\
\hline Pheophytin A & $\begin{array}{c}\text { S. fulvellum } \\
\text { (Brown alga, Japan) }\end{array}$ & $3.9 \mu \mathrm{g} / \mathrm{mL}$ & PC12 cells & $\begin{array}{l}\text { NGF-independent neurite } \\
\text { outgrowth }\end{array}$ & $\begin{array}{l}\uparrow \mathrm{PKA} \text { and MAPK } 1 / 2 \\
\uparrow \mathrm{PI} 3 \mathrm{~K}\end{array}$ & [147] \\
\hline Dimethylsulfoniopropionate & - & $7.4 \mathrm{mM}$ & $\begin{array}{l}\text { Neuronal N2a and } \\
\text { glial OLN-93 cells }\end{array}$ & $\begin{array}{l}\text { Process outgrowth; } \\
\text { microtubule reorganization } \\
\text { and bundling }\end{array}$ & $\begin{array}{l}\uparrow \alpha \text {-tubulin } \\
\text { acetylation }\end{array}$ & [149] \\
\hline Fucoxanthin & - & $0.1-2 \mu \mathrm{M}$ & PC-12 cells & $\begin{array}{l}\text { NGF-independent neurite } \\
\text { outgrowth }\end{array}$ & n.d. & [136] \\
\hline
\end{tabular}

n.d.: not defined; -: information not available. 


\subsection{Neuroprotective Activity}

Compounds that possess antioxidant, anti-inflammatory, anti-amyloidogenic, and anti-aggregation, cholesterol homeostasis, and protein clearance activities are expected to show potential neuroprotective effects. Congruently, the following metabolites isolated from marine algae have been reported to confer neuroprotection against a range of toxic stimuli (Table 3).

Several studies reported the neuroprotective activity of fucoxanthin. For example, fucoxanthin attenuated $\beta$-amyloid oligomer-induced [164] and $\mathrm{H}_{2} \mathrm{O}_{2}$-induced [165] apoptosis and OS in SH-SY5Y cells through activating a pro-survival PI3K/Akt pathway and suppressing the proapoptotic ERK pathway. Fucoxanthin-mediated protection against $\mathrm{H}_{2} \mathrm{O}_{2}$-induced apoptosis in primary cerebellar granule neurons also involved a similar neuroprotective mechanism [165]. Co-incubation of fucoxanthin with A $\beta 1-42$ oligomers formed modified $A \beta 1-42$ oligomers, which were relatively less toxic to SH-SY5Y cells compared to A $\beta 1-42$ oligomers, indicating that fucoxanthin-triggered structural modification of A $\beta 1-42$ oligomers reduced their neurotoxicity [135]. Fucoxanthin, isolated from Undaria pinnatifida, also attenuated hypoxia/reoxygenation (H/R)-induced cellular injury in primary cortical [166] and hippocampal neurons [167]. Likewise, fucoxanthin suppressed oxygen-glucose deprivation/ reperfusion (OGD/R)-induced neuronal apoptosis, via activating the Nrf2/HO-1 signaling [168]. In the TBI model of mouse primary cortical neurons, fucoxanthin promoted neuronal survival against secondary injury and enhanced antioxidant enzymes such as HO-1 and NAD(P)H dehydrogenase [quinone] 1 (NQO-1) via activating Nrf2-ARE and Nrf2-autophagy pathways [169]. Fucoxanthin also attenuated both $\mathrm{A} \beta 1-42-$ and $\mathrm{H}_{2} \mathrm{O}_{2}$-induced toxicity in PC12 cells [136].

Zonarol (ZO), a para-hydroquinone-type molecule from Dictyopteris undulata protected against OS in HT22 hippocampal and cerebrocortical neurons by activating the Nrf2/ARE pathway [170]. It induced the expression of NQO-1, HO-1, and peroxiredoxin 4 (PRDX4) and thus helps regulate intracellular redox state [170]. $\alpha$-Bisabolol, an active compound of Padina gymnospora, protected against A $325-35$-induced neurotoxicity in PC12 cells [137] and also in Neuro2a cells and transgenic C. elegans [171]. In PC12 cells, the rescuing effects of $\alpha$-bisabolol against A $\beta$ induced neurotoxicity were similar to donepezil, which is a currently prescribed anti-AD drug [137]. In Neuro2a cells, $\alpha$-bisabolol exhibited inhibition against cholinesterase and $\beta$-secretase activity. In addition, $\alpha$-bisabolol prevented apoptosis in Neuro2a cells by inhibiting the production of ROS and reactive nitrogen species (RNS) and reducing the expression of bcl-2-like protein (Bax) and caspase-3 [171]. In a transgenic C. elegans Alzheimer's model, $\alpha$-bisabolol attenuated $A \beta$-induced proteotoxicity by decreasing the expression of angiotensin-converting enzyme 1 (ace-1), hsp-4, and $A \beta$ [171]. The neuroprotective roles of fucosterol have been reviewed in our recent article [81]. In brief, fucosterol attenuated A $\beta$-induced neurotoxicity in hippocampal neurons [172] and SH-SY5Y cells [173]. In addition, three isolated compounds including $\alpha$-tocospirone, (23E)-3 $\beta$-hydroxy-stigmasta-5,23-dien-28-one and (22E)-3 $\beta$-hydroxy-cholesta-5,22-dien-24-one from Caulerpa racemose attenuated $\mathrm{A} \beta 25-35$-induced toxicity in SHSY5Y cells [174].

Phlorotannins, a specialized group of tannins, particularly rich in brown algae, have shown significant neuroprotective effects in several neurotoxicity models. Liu and colleagues evaluated three phlorotannins, including 8,8'-bieckol, dieckol, and eckol for their neuroprotection against

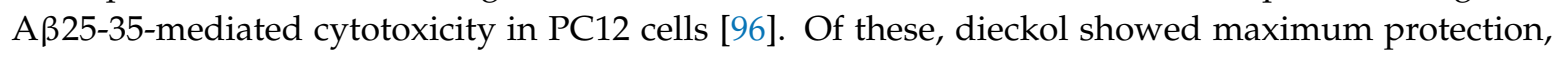
although all were shown to suppress inflammatory response by inactivating the NF- $\kappa B$ pathway [96]. A similar study by Ahn and teams demonstrated that six phlorotannins, such as phloroglucinol, dioxinodehydroeckol, eckol, dieckol, phlorofucofuroeckol A, and 7-phloroeckol from Eisenia bicyclis protected against $\mathrm{A} \beta$-induced cytotoxicity by inhibiting ROS generation and $\mathrm{Ca}^{2+}$ release [175]. Dieckol attenuated glutamate-induced excitotoxicity in primary cortical neurons and HT22 neurons by scavenging ROS and nuclear factor-like 2/heme oxygenase-1 pathway [176]. In addition, in another study, phloroglucinol from E. cava suppressed A $\beta 1-42$-provoked ROS accumulation in an HT-22 hippocampal cell line [177]. 
Table 3. Neuroprotective activity of algal compounds in vitro and in vivo.

\begin{tabular}{|c|c|c|c|c|c|c|c|}
\hline $\begin{array}{l}\text { Compound } \\
\text { (Class) }\end{array}$ & $\begin{array}{l}\text { Algal Origin (If } \\
\text { Any) }\end{array}$ & $\begin{array}{c}\text { Effective } \\
\text { Concentration }\end{array}$ & $\begin{array}{l}\text { Experimental Model (In } \\
\text { Vivo/In Vitro) }\end{array}$ & $\begin{array}{c}\text { Cellular } \\
\text { Effects/Significant } \\
\text { Findings }\end{array}$ & $\begin{array}{l}\text { Signaling } \\
\text { Pathways } \\
\text { Involved }\end{array}$ & Pharmacological Markers & References \\
\hline \multicolumn{8}{|c|}{ In Vitro Experimental Models } \\
\hline $\begin{array}{c}\text { Zonarol } \\
\text { (p-hydroquinone } \\
\text { sesquiterpene) }\end{array}$ & $\begin{array}{l}\text { Dictyopteris } \\
\text { undulate } \\
\text { (Brown alga, } \\
\text { Japan) }\end{array}$ & $\begin{array}{c}\mathrm{ED}_{50} 0.22 \mu \mathrm{M} \\
\text { (therapeutic index, } \\
\text { defined as the ratio of } \\
\mathrm{ED}_{50} \text { to } \mathrm{LD}_{50,} \text {, is } \\
14.2 \text {-fold) }\end{array}$ & $\begin{array}{c}\text { HT22 hippocampal neuronal } \\
\text { cells (glutamate-induced } \\
\text { oxidative stress) } \\
\& \\
\text { Cerebrocortical neurons } \\
\text { (glutamate or rotenone-induced } \\
\text { oxidative stress) }\end{array}$ & $\begin{array}{l}\text { Neuronal survival } \\
\text { against oxidative stress }\end{array}$ & $\begin{array}{l}\text { Nrf2/ARE } \\
\text { pathway }\end{array}$ & $\uparrow N Q O-1, \mathrm{HO}-1$, and PRDX4 & {$[170]$} \\
\hline Fucoxanthin & Undaria pinnatifida & $0.15-1.5 \mu \mathrm{mol} / \mathrm{L}$ & $\begin{array}{c}\text { Hypoxia/reoxygenation-induced } \\
\text { neuronal injury }\end{array}$ & $\begin{array}{c}\text { Neuronal survival } \\
\text { against oxidative stress }\end{array}$ & n.d. & n.d. & [166] \\
\hline Fucoxanthin & - & $20 \mu \mathrm{M}$ & $\begin{array}{l}\text { In Vitro model of TBI (primary } \\
\text { culture of mouse cortical } \\
\text { neurons scratched manually) }\end{array}$ & $\begin{array}{l}\text { Neuronal survival } \\
\text { against secondary injury } \\
\text { (oxidative stress) }\end{array}$ & $\begin{array}{l}\text { Nrf2-ARE and } \\
\text { Nrf2-autophagy } \\
\text { pathways }\end{array}$ & $\begin{array}{c}\downarrow R \text { ROS } \\
\uparrow \text { Beclin-1 (Atg6), LC3 (Atg8) } \\
\text { and } \downarrow \text { p2 } \\
\downarrow \text { Cleaved caspase-3 } \\
\uparrow \text { Nrf2 nuclear translocation } \\
\uparrow \text { HO-1 and NQO-1 } \\
\end{array}$ & [169] \\
\hline Fucoxanthin & - & $3 \mu \mathrm{M}$ & $\begin{array}{c}\beta \text {-Amyloid oligomer-induced } \\
\text { neurotoxicity in SH-SY5Y Cells }\end{array}$ & $\begin{array}{l}\text { Neuronal survival } \\
\text { against oxidative stress }\end{array}$ & $\begin{array}{c}\text { PI3K/Akt and ERK } \\
\text { Pathways }\end{array}$ & $\begin{array}{c}\downarrow \text { ROS } \\
\uparrow p S e r 473-A k t \text { and } \\
\text { pSer9-GSK3 } \beta \\
\downarrow \text { pERK }\end{array}$ & [164] \\
\hline Fucoxanthin & - & $1-3 \mu \mathrm{M}$ & $\begin{array}{l}\mathrm{H}_{2} \mathrm{O}_{2} \text {-induced toxicity in } \\
\text { SH-SY5Y Cells and primary } \\
\text { cerebellar granule neurons }\end{array}$ & $\begin{array}{l}\text { Neuronal survival } \\
\text { against oxidative stress }\end{array}$ & $\begin{array}{c}\text { PI3K/Akt and ERK } \\
\text { Pathways }\end{array}$ & $\begin{array}{c}\downarrow \text { ROS } \\
\uparrow p S e r 473-A k t \text { and } \\
\text { pSer9-GSK3 } \beta \\
\downarrow \text { pERK }\end{array}$ & [165] \\
\hline Fucoxanthin & - & $0.3 \mu \mathrm{M}$ & $\begin{array}{l}\text { Fucoxanthin-modified A } \beta_{1-42} \\
\text { oligomers-induced } \\
\text { neurotoxicity in SH-SY5Y Cells }\end{array}$ & Neuronal survival & n.d. & n.d. & [135] \\
\hline Fucoxanthin & - & $5 \mu \mathrm{M}, 10 \mu \mathrm{M}$, and $20 \mu \mathrm{M}$ & $\begin{array}{c}\text { Oxygen-glucose deprivation } \\
\text { and reoxygenation (OGD/R) } \\
\text { model of cultured neurons }\end{array}$ & $\begin{array}{l}\text { Neuronal survival } \\
\text { against oxidative stress }\end{array}$ & $\begin{array}{l}\text { Nrf2/HO-1 } \\
\text { signaling }\end{array}$ & $\begin{array}{c}\uparrow \mathrm{Nrf2} \text { nuclear translocation } \\
\uparrow \mathrm{HO}-1\end{array}$ & [168] \\
\hline Fucoxanthin & Undaria pinnatifida & $0.075 \mu \mathrm{g} / \mathrm{mL}$ & $\begin{array}{l}\mathrm{H} / \mathrm{R} \text {-induced excitotoxicity in } \\
\text { primary hippocampal neurons }\end{array}$ & $\begin{array}{c}\text { Neuronal survival } \\
\text { against oxidative stress }\end{array}$ & n.d. & n.d. & [167] \\
\hline
\end{tabular}


Table 3. Cont.

\begin{tabular}{|c|c|c|c|c|c|c|c|}
\hline $\begin{array}{l}\text { Compound } \\
\text { (Class) }\end{array}$ & $\begin{array}{l}\text { Algal Origin (If } \\
\text { Any) }\end{array}$ & $\begin{array}{c}\text { Effective } \\
\text { Concentration }\end{array}$ & $\begin{array}{l}\text { Experimental Model (In } \\
\text { Vivo/In Vitro) }\end{array}$ & $\begin{array}{c}\text { Cellular } \\
\text { Effects/Significant } \\
\text { Findings } \\
\end{array}$ & $\begin{array}{l}\text { Signaling } \\
\text { Pathways } \\
\text { Involved }\end{array}$ & Pharmacological Markers & References \\
\hline Fucoxanthin & - & $\begin{array}{c}<2 \mu \mathrm{M} \text { (against } \\
\mathrm{A} \beta 1-42 \text {-mediated } \\
\text { toxicity) } \\
0.5-2 \mu \mathrm{M}\left(\mathrm{H}_{2} \mathrm{O}_{2} \text {-induced }\right. \\
\text { cytotoxicity) }\end{array}$ & $\begin{array}{l}\text { A } \beta 1-42 \text {-mediated toxicity in } \\
\text { PC12 cells } \\
\mathrm{H}_{2} \mathrm{O}_{2} \text {-induced cytotoxicity }\end{array}$ & Cell survival & n.d. & n.d. & [136] \\
\hline$\alpha$-Bisabolol & Padina gymnospora & $5 \mu \mathrm{g} / \mathrm{mL}$ & $\begin{array}{l}\text { A } \beta 25-35 \text {-induced neurotoxicity } \\
\text { in PC-12 cells }\end{array}$ & Antiapoptosis & n.d. & n.d. & [137] \\
\hline$\alpha$-Bisabolol & Padina gymnospora & 5 and $10 \mu \mathrm{g} / \mathrm{mL}$ & $\begin{array}{c}\text { A } \beta 25-35-i n d u c e d \text { neurotoxicity } \\
\text { in Neuro2a cells and transgenic } \\
\text { C. elegans }\end{array}$ & $\begin{array}{c}\text { Antioxidation } \\
\text { Antiapoptosis; } \\
\text { Protection against } \mathrm{A} \beta \\
\text { induced proteotoxicity }\end{array}$ & $\begin{array}{l}\mathrm{A} \beta \text { mediated } \\
\text { pathway }\end{array}$ & $\begin{array}{c}\downarrow R O S, \text { NOS } \\
\downarrow \text { Bax and caspase- } 3 \\
\downarrow \text { ace- } 1 \text {, hsp-4 and A } \beta\end{array}$ & [171] \\
\hline Fucosterol & $\begin{array}{l}\text { Ecklonia } \\
\text { stolonifera }\end{array}$ & $\begin{array}{l}\text { 1-10 } \mu \mathrm{M} \text { at } 24 \mathrm{~h} \text { before } \\
\mathrm{sA} \beta 1-42 \text { exposure } \\
\text { (effective fucosterol } \\
\text { conc. } 5-10 \mu \mathrm{M} \text { ) }\end{array}$ & $\begin{array}{c}\text { sA } \beta 1-42(10 \mu \mathrm{M}) \text {-induced ER } \\
\text { stress model of primary } \\
\text { neurons }\end{array}$ & $\begin{array}{c}\text { Attenuates } \\
\text { A } \beta 1 \text {-42-induced } \\
\text { neurotoxicity }\end{array}$ & n.d. & $\begin{array}{c}\uparrow \text { TrkB-mediated ERK1/2 } \\
\text { signaling } \\
\text { \GRP78 expression } \\
\uparrow B D N F \text { expression } \\
\end{array}$ & [172] \\
\hline Fucosterol & - & 0.0032 to $20 \mu \mathrm{M}$ & $\begin{array}{c}\text { A } \beta \text {-induced cytotoxicity in } \\
\text { SH-SY5Y cells }\end{array}$ & $\begin{array}{l}\text { Reduces apoptosis in } \\
\text { A } \beta \text {-induced SH-SY5Y } \\
\text { cells }\end{array}$ & n.d. & $\begin{array}{c}\uparrow N g b \text { mRNA } \\
\downarrow A P P \text { mRNA and } \\
\text { intracellular A } \beta \text { levels }\end{array}$ & [173] \\
\hline $\begin{array}{l}\text { Eckol, dieckol and } \\
\text { 8,8'-bieckol }\end{array}$ & Ecklonia cava & $1-50 \mu \mathrm{M}$ & A $\beta 25-35$-stimulated PC12 cells & $\begin{array}{c}\text { Antioxidation, } \\
\text { anti-inflammation, } \\
\text { anti-apoptotic } \\
\text { properties }\end{array}$ & NF-кB pathway & $\begin{array}{c}\downarrow C O X-2, \text { iNOS; } \\
\downarrow \text { TNF- } \alpha, \text { IL- } 1 \beta \text { and PGE } 2 \\
\text { production; } \\
\downarrow \text { p38, ERK and JNK }\end{array}$ & [96] \\
\hline $\begin{array}{l}\text { Phloroglucinol, } \\
\text { eckol, } \\
\text { triphloroethol A, } \\
\text { eckstolonol, and } \\
\text { dieckol }\end{array}$ & Ecklonia cava & $50 \mu \mathrm{M}$ & $\begin{array}{c}\mathrm{H}_{2} \mathrm{O}_{2} \text {-induced oxidative stress } \\
\text { in murine hippocampal } \mathrm{HT} 22 \\
\text { cells }\end{array}$ & $\begin{array}{c}\downarrow \text { Lipid peroxidation; } \\
\quad \downarrow \text { apoptosis }\end{array}$ & n.d. & $\begin{array}{c}\downarrow \mathrm{ROS}^{2+} \\
\downarrow \mathrm{Ca}^{2+} \text { release }\end{array}$ & [178] \\
\hline $\begin{array}{l}\text { Diphlorethohydro } \\
\text { xycarmalol }\end{array}$ & Ishige okamurae & $50 \mu \mathrm{M}$ & $\begin{array}{c}\mathrm{H}_{2} \mathrm{O}_{2} \text {-induced oxidative stress } \\
\text { in murine hippocampal } \mathrm{HT} 22 \\
\text { cells }\end{array}$ & $\begin{array}{c}\text { Antioxidation; } \\
\downarrow \text { Lipid peroxidation; } \\
\downarrow \text { Appoptosis }\end{array}$ & n.d. & $\begin{array}{c}\downarrow \text { Bax } \\
\uparrow \text { Bcl-xL } \\
\downarrow \text { Poly (ADP-ribose) } \\
\text { polymerase-1 (PARP) } \\
\text { cleavage } \\
\downarrow \text { ROS } \\
\downarrow \mathrm{Ca}^{2+} \text { release }\end{array}$ & [179] \\
\hline
\end{tabular}


Table 3. Cont.

\begin{tabular}{|c|c|c|c|c|c|c|c|}
\hline $\begin{array}{l}\text { Compound } \\
\text { (Class) }\end{array}$ & $\begin{array}{l}\text { Algal Origin (If } \\
\text { Any) }\end{array}$ & $\begin{array}{c}\text { Effective } \\
\text { Concentration }\end{array}$ & $\begin{array}{l}\text { Experimental Model (In } \\
\text { Vivo/In Vitro) }\end{array}$ & $\begin{array}{c}\text { Cellular } \\
\text { Effects/Significant } \\
\text { Findings }\end{array}$ & $\begin{array}{l}\text { Signaling } \\
\text { Pathways } \\
\text { Involved }\end{array}$ & Pharmacological Markers & References \\
\hline $\begin{array}{c}\text { Phloroglucinol, } \\
\text { dioxinodehydroeckol, } \\
\text { eckol, } \\
\text { phlorofucofuroeckol } \\
\text { A, dieckol, and } \\
\text { 7-phloroeckol } \\
\end{array}$ & Eisenia bicyclis & $2.5,5,10$ and $20 \mu \mathrm{g} / \mathrm{mL}$ & $\begin{array}{c}\text { A } \beta \text { peptide-induced toxicity in } \\
\text { PC12 cells }\end{array}$ & Antioxidation & n.d. & $\begin{array}{c}\downarrow \mathrm{ROOS}^{2+} \\
\downarrow \mathrm{Ca}^{2+} \text { release }\end{array}$ & [175] \\
\hline Phlorofucofuroeckol & Brown algae & $10 \mu \mathrm{M}$ & $\begin{array}{l}\text { Glutamate-induced cytotoxicity } \\
\text { in PC12 }\end{array}$ & Antioxidation & n.d. & $\downarrow$ Caspase- $3,-8$, and PARP & [180] \\
\hline $\begin{array}{c}\text { Eckmaxol } \\
\text { (phlorotannin) }\end{array}$ & Ecklonia maxima & $20 \mu \mathrm{M}$ & $\begin{array}{l}\beta \text {-amyloid oligomer -induced } \\
\text { neuronal apoptosis in SH-SY5Y } \\
\text { cells }\end{array}$ & $\downarrow$ Apoptosis & $\begin{array}{l}\text { GSK- } 3 \beta \text { and ERK } \\
\text { pathways }\end{array}$ & $\begin{array}{l}\uparrow p G S K-3 \beta \\
\downarrow p E R K \\
\uparrow \text { HO- } 1\end{array}$ & [181] \\
\hline Fucoidan & - & $0.1-1.0 \mu \mathrm{M}$ & $\begin{array}{c}\mathrm{A} \beta_{1-42} \text {-induced neurotoxicity } \\
\text { in rat cholinergic basal } \\
\text { forebrain neurons }\end{array}$ & $\begin{array}{l}\text { Restores A } \beta \text {-induced } \\
\text { reduction in whole-cell } \\
\text { currents }\end{array}$ & n.d. & $\begin{array}{c}\uparrow p P K C \\
\downarrow \text { ROS } \\
\downarrow \text { caspases } 9 \text { and } 3\end{array}$ & [182] \\
\hline $\begin{array}{c}\text { Fucoidan } \\
\text { (sulfated } \\
\text { polysaccharide) }\end{array}$ & - & 0.1 and $1.0 \mathrm{mg} / \mathrm{mL}$ & $\begin{array}{l}\text { MPP(+)-induced injury in } \\
\text { MN9D cells }\end{array}$ & $\begin{array}{c}\text { Antioxidation; } \\
\text { Protects cellular injury }\end{array}$ & n.d. & n.d. & [183] \\
\hline $\begin{array}{c}\text { Fucoidan } \\
\text { (sulfated } \\
\text { polysaccharide) }\end{array}$ & - & 60 and $30 \mu \mathrm{g} / \mathrm{mL}$ & $\begin{array}{c}\mathrm{H}_{2} \mathrm{O}_{2} \text {-induced apoptosis in } \\
\text { PC12 cells }\end{array}$ & $\begin{array}{l}\uparrow \text { Cell viability; } \\
\text { antioxidation }\end{array}$ & PI3K/Akt signaling & $\begin{array}{c}\downarrow \text { ROS; } \\
\uparrow S O D \text { and GPx activities; } \\
\downarrow \text { MDA; } \\
\uparrow \text { Bcl-2/Bax ratio; } \\
\downarrow \text { caspase-3; } \\
\uparrow p-A k t\end{array}$ & [184] \\
\hline $\begin{array}{c}\text { Fucoidan } \\
\text { (sulfated } \\
\text { polysaccharide) }\end{array}$ & - & $100,200,400 \mu \mathrm{g} / \mathrm{mL}$ & $\begin{array}{l}\text { A } \beta 25-35 \text { and d-Gal-induced } \\
\text { neurotoxicity in PC12 cells }\end{array}$ & $\downarrow$ Apoptosis & $\begin{array}{l}\text { Caspase-dependent } \\
\text { apoptosis pathway }\end{array}$ & $\begin{array}{c}\downarrow \text { Cytochrome c release; } \\
\downarrow \text { Caspase activation; } \\
\uparrow \text { Livin and XIAP; } \\
\uparrow S O D \\
\uparrow G S H\end{array}$ & [185] \\
\hline $\begin{array}{c}\text { Fucoidan } \\
\text { (sulfated } \\
\text { polysaccharide) }\end{array}$ & - & $100 \mu \mathrm{M}$ & $\begin{array}{l}\mathrm{MPP}(+) \text {-induced injury in } \\
\text { dopaminergic precursor cell } \\
\text { line(MN9D) cells }\end{array}$ & $\begin{array}{l}\downarrow \text { Apoptosis; } \\
\text { Antioxidation; }\end{array}$ & $\begin{array}{l}\text { CatD-Bax } \\
\text { signaling axis }\end{array}$ & $\begin{array}{c}\downarrow \text { LC3-II and CatD; } \\
\downarrow \text { Bax; } \\
\uparrow \text { SOD } \\
\uparrow \mathrm{GSH}\end{array}$ & [186] \\
\hline
\end{tabular}


Table 3. Cont

\begin{tabular}{|c|c|c|c|c|c|c|c|}
\hline $\begin{array}{l}\text { Compound } \\
\text { (Class) }\end{array}$ & $\begin{array}{l}\text { Algal Origin (If } \\
\text { Any) }\end{array}$ & $\begin{array}{c}\text { Effective } \\
\text { Concentration }\end{array}$ & $\begin{array}{c}\text { Experimental Model (In } \\
\text { Vivo/In Vitro) }\end{array}$ & $\begin{array}{c}\text { Cellular } \\
\text { Effects/Significant } \\
\text { Findings }\end{array}$ & $\begin{array}{l}\text { Signaling } \\
\text { Pathways } \\
\text { Involved }\end{array}$ & Pharmacological Markers & References \\
\hline $\begin{array}{l}\text { Fucoidan } \\
\text { (sulfated } \\
\text { polysaccharide) }\end{array}$ & $\begin{array}{l}\text { Fucus vesiculosus } \\
\text { Linn., brown alga }\end{array}$ & $0.5 \mathrm{mg} / \mathrm{mL}$ or $1.5 \mathrm{mg} / \mathrm{mL}$ & $\begin{array}{l}\text { NMDA-induced } \mathrm{Ca}^{2+} \\
\text { responses in culture rat neurons }\end{array}$ & $\begin{array}{c}\text { Suppresses the } \\
\text { intracellular } \mathrm{Ca}^{2+} \\
\text { responses by selectively } \\
\text { inhibiting NMDA } \\
\text { receptors in cortical } \\
\text { neurons and l-type } \mathrm{Ca}^{2+} \\
\text { channels in } \\
\text { hippocampal neurons. }\end{array}$ & n.d. & $\begin{array}{c}\downarrow \text { GluNR1 mRNA and } \\
\text { 1-type } \mathrm{Ca}^{2+} \text { channels, } \\
\text { PR1/PR2 }\end{array}$ & [187] \\
\hline Oligo-porphyran & $\begin{array}{l}\text { Synthesized from } \\
\text { porphyran } \\
\text { (isolated from } \\
\text { Pyropia yezoensis) } \\
\text { through acidolysis } \\
\text { reaction }\end{array}$ & $200 \mu \mathrm{g} / \mathrm{mL}$ & $\begin{array}{l}\text { 6-OHDA-induced cytotoxicity } \\
\text { in PC12 cells }\end{array}$ & $\begin{array}{c}\downarrow \text { Apoptosis; } \\
\text { Antioxidation; } \\
\text { Anti-inflammation }\end{array}$ & $\begin{array}{l}\text { PI3K/ Akt/PKC } \\
\text { pathway }\end{array}$ & $\begin{array}{c}\downarrow R O S ; \uparrow M M P \\
\uparrow S O D \text { and GSH; } \\
\uparrow \text { Bcl- } 2 / \text { Bax ratio; } \\
\downarrow \text { caspase- } 3 \text { and }-9 \\
\uparrow p-A k t, p-\text { PI3K, PKC } \\
\uparrow D A T \text { and TH } \\
\downarrow \text { TNF- } \alpha, \text { IL- } 1 \beta \text {, and IL-6 }\end{array}$ & [188] \\
\hline $\begin{array}{c}\text { Acidic } \\
\text { oligosaccharide } \\
\text { sugar chain }\end{array}$ & $\begin{array}{l}\text { Echlonia kurome } \\
\text { Okam }\end{array}$ & $50,75,100 \mu \mathrm{g} / \mathrm{mL}$ & $\begin{array}{l}\text { Inflammatory responses and } \\
\text { cytotoxicity in SH-SY5Y cell } \\
\text { line induced by A } \beta \text {-stimulated } \\
\text { astrocytes conditioned medium }\end{array}$ & Oxidative stress & n.d. & $\begin{array}{l}\downarrow \text { TNF- } \alpha \text { and IL-6; } \\
\downarrow \mathrm{Ca}^{2+} \text { influx }\end{array}$ & [189] \\
\hline $\begin{array}{l}\text { Racemosins A } \\
\text { (bisindole } \\
\text { alkaloid) }\end{array}$ & $\begin{array}{l}\text { Caulerpa racemosa, } \\
\text { green alga }\end{array}$ & $10 \mu \mathrm{M}$ & $\begin{array}{c}\text { A } \beta 25-35 \text {-induced SH-SY5Y cell } \\
\text { damage }\end{array}$ & $\begin{array}{l}\uparrow \text { Cell viability; } \\
\downarrow \text { aapoptosis }\end{array}$ & n.d. & & [190] \\
\hline $\begin{array}{l}\text { Tramiprosate } \\
\text { (small } \\
\text { aminosulphonate } \\
\text { compound) }\end{array}$ & Red marine algae & $50 \mathrm{mg} / \mathrm{kg}$ & $\begin{array}{l}\text { OGD- or NMDA-induced } \\
\text { injury in NGF-differentiated } \\
\text { PC12 cells and primary cortical } \\
\text { neurons }\end{array}$ & $\begin{array}{l}\text { Protects against } \\
\text { neuronal injury }\end{array}$ & n.d. & & [191] \\
\hline $\begin{array}{l}\text { Dimethylsulfonio } \\
\text { propionate }\end{array}$ & - & $1 \mathrm{mg} / \mathrm{mL}$ & $\begin{array}{l}\text { Tropodithietic acid -induced } \\
\text { cytotoxicity in OLN-93 and N2a } \\
\text { cells }\end{array}$ & $\begin{array}{l}\text { Protects against } \\
\text { neurotoxicity; } \\
\text { Attenuates stress } \\
\text { responses and } \\
\text { mitochondrial damage }\end{array}$ & n.d. & $\begin{array}{l}\downarrow E R K 1 / 2 \text { activation and } \\
\text { HSP32 induction }\end{array}$ & [149] \\
\hline $\begin{array}{l}\text { k- Carrageenan- } \\
\text { derived } \\
\text { pentasaccharide }\end{array}$ & marine red algae & 25,50 , or $100 \mu \mathrm{M}$ & $\begin{array}{c}\text { A } \beta 25-35 \text {-induced neurotoxicity } \\
\text { in SH-SY5Y cells }\end{array}$ & $\begin{array}{l}\uparrow \text { Cell viability; } \\
\downarrow \text { Apoptosis }\end{array}$ & $\begin{array}{l}\text { JNK signaling } \\
\text { pathway }\end{array}$ & $\begin{array}{c}\downarrow \text { Cleaved caspase } 3 \\
\downarrow \text { p-JNK }\end{array}$ & [192] \\
\hline
\end{tabular}


Table 3. Cont.

\begin{tabular}{|c|c|c|c|c|c|c|c|}
\hline $\begin{array}{l}\text { Compound } \\
\text { (Class) }\end{array}$ & $\begin{array}{l}\text { Algal Origin (If } \\
\text { Any) }\end{array}$ & $\begin{array}{c}\text { Effective } \\
\text { Concentration }\end{array}$ & $\begin{array}{c}\text { Experimental Model (In } \\
\text { Vivo/In Vitro) }\end{array}$ & $\begin{array}{c}\text { Cellular } \\
\text { Effects/Significant } \\
\text { Findings }\end{array}$ & $\begin{array}{l}\text { Signaling } \\
\text { Pathways } \\
\text { Involved }\end{array}$ & Pharmacological Markers & References \\
\hline $\begin{array}{c}\text { Fucoidan } \\
\text { (sulfated } \\
\text { polysaccharide) }\end{array}$ & - & $25 \mathrm{mg} / \mathrm{kg}$ & $\begin{array}{l}\text { MPTP-induced animal model of } \\
\text { Parkinsonism in C57/BL mice } \\
\text { in vivo }\end{array}$ & $\begin{array}{c}\downarrow \text { Behavioral deficits; } \\
\downarrow \text { TH-positive neuronal } \\
\text { loss }\end{array}$ & n.d. & $\begin{array}{c}\text { ^Dopamine, DOPAC and } \\
\text { HVA; } \\
\uparrow \text { Tyrosine hydroxylase; } \\
\uparrow G S H ; \\
\uparrow S O D, G P x \text {, and catalase } \\
\text { activity and total } \\
\text { antioxidant capacity; }\end{array}$ & [183] \\
\hline $\begin{array}{l}\text { Fucoidan } \\
\text { (sulfated } \\
\text { polysaccharide) }\end{array}$ & - & $\begin{array}{l}7.5 \text { and } 15 \mathrm{mg} / \mathrm{kg} \text { body } \\
\text { wt (intranigral injection) }\end{array}$ & $\begin{array}{l}\text { LPS-induced neurotoxicity in } \\
\text { rat }\end{array}$ & $\begin{array}{l}\text { Ameliorates behavioral } \\
\text { deficits, prevents the } \\
\text { loss of dopaminergic } \\
\text { neurons and inhibits the } \\
\text { deleterious activation of } \\
\text { microglia in the } \\
\text { substantia nigra pars } \\
\text { compacta }\end{array}$ & n.d. & $\downarrow \mathrm{CD} 11 \mathrm{~b}$ & [93] \\
\hline $\begin{array}{l}\text { Fucoidan } \\
\text { (sulfated } \\
\text { polysaccharide) }\end{array}$ & - & $50,100,200 \mathrm{mg} \mathrm{kg}^{-1}$ & $\begin{array}{l}\text { A } \beta 1-40 \text {-induced learning and } \\
\text { memory impairment in rats }\end{array}$ & $\begin{array}{c}\text { Ameliorates learning } \\
\text { and memory } \\
\text { impairment; } \\
\text { boxidative stress; } \\
\downarrow \text { apoptosis }\end{array}$ & Antioxidation & $\begin{array}{c}\uparrow \text { ChAT, SOD and GPx } \\
\text { activity; } \\
\uparrow \text { Ach; } \\
\downarrow \text { AchE activity; } \\
\downarrow \text { MDA; } \\
\uparrow \text { Bcl-2/Bax ratio; } \\
\downarrow \text { caspase-3 activity }\end{array}$ & [193] \\
\hline $\begin{array}{c}\text { Fucoidan } \\
\text { (sulfated } \\
\text { polysaccharide) }\end{array}$ & - & $\begin{array}{c}100 \text { and } 200 \mathrm{mg} / \mathrm{kg} \text { on } \\
\text { day } 2-6,50 \mathrm{mg} / \mathrm{kg} \text { on } \\
\text { day } 4-6\end{array}$ & $\begin{array}{l}\text { d-Gal-induced cognitive } \\
\text { dysfunction in mice }\end{array}$ & $\begin{array}{l}\downarrow \text { Apoptosis; } \\
\text { ameliorate the learning } \\
\text { and memory } \\
\text { impairment }\end{array}$ & $\begin{array}{l}\text { Caspase-dependent } \\
\text { apoptosis pathway }\end{array}$ & $\begin{array}{c}\uparrow \text { Ach level and ChAT } \\
\text { activity; } \\
\downarrow \text { AChE activity; } \\
\uparrow S O D ; \\
\uparrow G S H\end{array}$ & [185] \\
\hline $\begin{array}{c}\text { Fucoidan } \\
\text { (sulfated } \\
\text { polysaccharide) }\end{array}$ & - & $100-500 \mathrm{ng} / \mathrm{mL}$ & Transgenic C. elegans AD model & $\begin{array}{c}\text { Alleviates the paralyzed } \\
\text { phenotype; } \\
\downarrow \mathrm{A} \beta \text { deposits }\end{array}$ & n.d. & $\begin{array}{c}\uparrow \text { Proteasomal activity } \\
\text { (proteolysis); } \\
\downarrow \text { ROS }\end{array}$ & [194] \\
\hline $\begin{array}{l}\text { Fucoidan-rich } \\
\text { substances }\end{array}$ & E. cava & $\begin{array}{l}\text { Polyphenol/fucoidan } \\
\text { extract and mixture (4:6) }\end{array}$ & $\begin{array}{l}\text { Trimethyltin-induced cognitive } \\
\text { dysfunction model }\end{array}$ & $\begin{array}{l}\text { Ameliorates learning } \\
\text { and memory } \\
\text { impairment }\end{array}$ & n.d. & $\begin{array}{c}\downarrow R O S ; \uparrow M M P ; \\
\downarrow \text { BAX and cytochrome C } \\
\text { release; } \\
\downarrow \text { Amyloid } \beta \text { production; } \\
\downarrow \text { Tau hyperphosphorylation }\end{array}$ & [195] \\
\hline Fucoidan & - & $50 \mathrm{mg} / \mathrm{kg}$ & $\begin{array}{l}\text { Transient global cerebral } \\
\text { ischemia (tGCI) model of } \\
\text { gerbils }\end{array}$ & $\begin{array}{l}\downarrow \text { Oxidative stress and } \\
\text { glial activation }\end{array}$ & n.d. & $\uparrow S O D 1$ and SOD2 & [196] \\
\hline
\end{tabular}


Table 3. Cont

\begin{tabular}{|c|c|c|c|c|c|c|c|}
\hline $\begin{array}{l}\text { Compound } \\
\text { (Class) }\end{array}$ & $\begin{array}{l}\text { Algal Origin (If } \\
\text { Any) }\end{array}$ & $\begin{array}{c}\text { Effective } \\
\text { Concentration }\end{array}$ & $\begin{array}{c}\text { Experimental Model (In } \\
\text { Vivo/In Vitro) }\end{array}$ & $\begin{array}{c}\text { Cellular } \\
\text { Effects/Significant } \\
\text { Findings } \\
\end{array}$ & $\begin{array}{l}\text { Signaling } \\
\text { Pathways } \\
\text { Involved }\end{array}$ & Pharmacological Markers & References \\
\hline $\begin{array}{c}\text { Laminarin } \\
\text { (polysaccharide) }\end{array}$ & - & $\begin{array}{c}50 \text { or } 100 \mathrm{mg} / \mathrm{kg} \text { (i.p) } \\
\text { for seven days before IR } \\
\text { (5-min transient } \\
\text { ischemia) surgery }\end{array}$ & $\begin{array}{l}\text { Forebrain } \mathrm{I} / \mathrm{R} \text { injury in young } \\
\text { gerbils ( } 6 \text { months) }\end{array}$ & $\begin{array}{c}\downarrow \text { Reactive gliosis (M1 } \\
\text { microglia) and } \\
\text { neuroinflammation }\end{array}$ & n.d. & $\downarrow \mathrm{IL}-2$ & [197] \\
\hline $\begin{array}{c}\text { Laminarin } \\
\text { (polysaccharide) }\end{array}$ & Brown algae & $\begin{array}{c}50 \mathrm{mg} / \mathrm{kg} / \text { day (i.p) } \\
\text { for seven days before IR } \\
\text { (5-min transient } \\
\text { ischemia) surgery }\end{array}$ & $\begin{array}{l}\text { Forebrain I/R injury in aged } \\
\text { gerbils (22-24 months) }\end{array}$ & $\begin{array}{l}\downarrow \text { Oxidative stress and } \\
\text { neuroinflammation }\end{array}$ & n.d. & $\begin{array}{c}\text { \Superoxide anions and } \\
\text { 4-hydroxy-2-nonenal (HNE) } \\
\downarrow \text { IL- } 1 \beta \text { and TNF- } \alpha \\
\uparrow \text { SOD1 and SOD2 } \\
\uparrow I L-4 \text { and IL-13 }\end{array}$ & [198] \\
\hline Oligo-porphyran & $\begin{array}{l}\text { Synthesized From } \\
\text { porphyran } \\
\text { (isolated from } \\
\text { Pyropia yezoensis) } \\
\text { through acidolysis } \\
\text { reaction }\end{array}$ & 25 and $50 \mathrm{mg} / \mathrm{kg}$ & $\begin{array}{l}\text { 6-OHDA-induced Parkinsonian } \\
\text { mice model }\end{array}$ & $\begin{array}{c}\downarrow \text { Apoptosis; } \\
\text { Ameliorates behavioral } \\
\text { deficits }\end{array}$ & $\begin{array}{l}\text { PI3K/Akt/Bcl-2 } \\
\text { pathway }\end{array}$ & $\begin{array}{c}\uparrow \mathrm{DAT} \text { and TH; } \\
\downarrow \text { caspase-3 and -9 } \\
\uparrow \mathrm{DA}, \mathrm{NE}, 5-\mathrm{HT}, \mathrm{DOPAC} \\
\uparrow \mathrm{p}-\mathrm{ERK} 1 / 2, \mathrm{DRD} 2 \\
\uparrow \mathrm{p}-\mathrm{Akt}, \mathrm{p}-\mathrm{PI} 3 \mathrm{~K}, \mathrm{GSK}-3 \beta \\
\uparrow \mathrm{Bcl}-2 / \mathrm{Bax} \text { ratio; } \\
\downarrow \mathrm{PARP} \text { and cytC } \\
\uparrow \mathrm{p}-\mathrm{TrkA} \text { and NGF } \\
\end{array}$ & [199] \\
\hline $\begin{array}{c}\text { Porphyran } \\
\text { (polysaccharide) }\end{array}$ & $\begin{array}{l}\text { Degraded } \\
\text { polysaccharide } \\
\text { from Pyropia } \\
\text { haitanensis }\end{array}$ & $75,150,300 \mathrm{mg} / \mathrm{kg}$ & $\begin{array}{l}\mathrm{A} \beta 1-40 \text {-induced mice AD } \\
\text { model }\end{array}$ & $\begin{array}{l}\text { Improved learning and } \\
\text { memory deficits }\end{array}$ & n.d. & $\begin{array}{c}\uparrow C h A T \text { activity; } \\
\downarrow \text { AChE activity; } \\
\uparrow \text { Ach }\end{array}$ & {$[200]$} \\
\hline Fucoxanthin & Brown seaweed & $50,100,200 \mathrm{mg} / \mathrm{kg}$ & $\begin{array}{l}\text { Scopolamine-induced cognitive } \\
\text { impairments in mice }\end{array}$ & $\begin{array}{l}\text { Memory enhancement; } \\
\text { anticholinesterase }\end{array}$ & n.d. & $\begin{array}{c}\downarrow \mathrm{AChE} \text { and choline } \\
\text { acetyltransferase } \\
\uparrow \mathrm{BDNF}\end{array}$ & [117] \\
\hline Fucoxanthin & - & $0.1-30 \mu \mathrm{M}$ & $\begin{array}{l}\mathrm{A} \beta \text { oligomer-induced cognitive } \\
\text { impairments in mice }\end{array}$ & $\begin{array}{c}\text { Memory enhancement, } \\
\text { attenuation of oxidative } \\
\text { stress }\end{array}$ & n.d. & $\uparrow B D N F$ & [135] \\
\hline Fucoxanthin & - & $5 \mu \mathrm{M}, 10 \mu \mathrm{M}$, and $20 \mu \mathrm{M}$ & $\begin{array}{c}\text { Middle cerebral artery } \\
\text { occlusion (MCAO) rat model } \\
\text { (cerebral ischemic/reperfusion } \\
\text { (I/R) injury) }\end{array}$ & $\begin{array}{l}\text { Improves the neurologic } \\
\text { deficit score and reduces } \\
\text { the infarct volume }\end{array}$ & n.d. & $\begin{array}{c}\uparrow \text { SOD activity } \\
\downarrow R O S, \text { MDA } \\
\downarrow \text { cleaved caspase-3 } \\
\uparrow \text { Bcl-2/Bax ratio } \\
\end{array}$ & [168] \\
\hline
\end{tabular}


Table 3. Cont.

\begin{tabular}{|c|c|c|c|c|c|c|c|}
\hline $\begin{array}{l}\text { Compound } \\
\text { (Class) }\end{array}$ & $\begin{array}{l}\text { Algal Origin (If } \\
\text { Any) }\end{array}$ & $\begin{array}{c}\text { Effective } \\
\text { Concentration }\end{array}$ & $\begin{array}{c}\text { Experimental Model (In } \\
\text { Vivo/In Vitro) }\end{array}$ & $\begin{array}{c}\text { Cellular } \\
\text { Effects/Significant } \\
\text { Findings } \\
\end{array}$ & $\begin{array}{l}\text { Signaling } \\
\text { Pathways } \\
\text { Involved }\end{array}$ & Pharmacological Markers & References \\
\hline Fucoxanthin & & $\begin{array}{l}100 \mathrm{mg} / \mathrm{kg} \text { and } \\
0.05 \mathrm{mmol} / \mathrm{L}\end{array}$ & $\begin{array}{l}\text { Traumatic brain injury (TBI) } \\
\text { model }\end{array}$ & $\begin{array}{c}\text { Anti-apoptosis, } \\
\text { attenuation of oxidative } \\
\text { stress, induction of } \\
\text { autophagy }\end{array}$ & $\begin{array}{l}\text { Nrf2-ARE and } \\
\text { Nrf2-autophagy } \\
\text { pathways }\end{array}$ & $\begin{array}{c}\uparrow G P x \\
\downarrow \text { MDA } \\
\downarrow \text { Cleaved caspase-3, PARP, } \\
\text { cytosolic cytochrome c } \\
\uparrow \text { Mitochondrial cytochrome } \\
\text { c } \\
\uparrow \text { Beclin-1 (Atg6), LC3 (Atg8) } \\
\text { and } \downarrow \text { p62 } \\
\uparrow \text { Nrf2 nuclear translocation } \\
\uparrow \text { HO- } 1 \text { and NQO-1 }\end{array}$ & [169] \\
\hline Fucosterol & Ecklonia stolonifera & $1-10 \mu \mathrm{M}$ & $\begin{array}{l}\text { sA } \beta 1-42 \text {-induced memory } \\
\text { dysfunction in aging rats }\end{array}$ & $\begin{array}{c}\text { Ameliorates } \\
\text { A } \beta 1-42 \text {-induced } \\
\text { memory impairment }\end{array}$ & n.d. & $\begin{array}{c}\uparrow \text { TrkB-mediated ERK1/2 } \\
\text { signaling } \\
\text { لGRP78 expression } \\
\uparrow B D N F \text { expression }\end{array}$ & [172] \\
\hline $\begin{array}{l}\text { Dieckol and } \\
\text { phlorofucofuroeckol }\end{array}$ & Ecklonia cava & $\begin{array}{c}\text { PFF }(0.2 \text { and } 2 \mathrm{mg} / \mathrm{kg}) \\
\text { and dieckol }(1 \text { and } \\
10 \mathrm{mg} / \mathrm{kg})\end{array}$ & $\begin{array}{l}\text { Ethanol-intoxicated } \\
\text { memory-impaired mice }\end{array}$ & $\begin{array}{c}\downarrow \mathrm{AChE} \text { activity; } \\
\text { reduces the inhibition of } \\
\text { latency }\end{array}$ & n.d. & $\uparrow A C h$ & {$[120]$} \\
\hline C-Phycocyanin & & $200 \mathrm{mg} / \mathrm{kg}$ & $\begin{array}{c}\text { Global cerebral } \\
\text { ischemia/reperfusion (I/R) } \\
\text { injury in gerbils }\end{array}$ & $\begin{array}{l}\text { Reduces the infarct } \\
\text { volume and improves } \\
\text { the neurologic deficit } \\
\text { score; } \\
\text { protects neurons, } \\
\text { improves the functional } \\
\text { outcome (locomotor } \\
\text { behavior) and promotes } \\
\text { survival }\end{array}$ & n.d. & $\downarrow \mathrm{MDA}$ & [201] \\
\hline $\begin{array}{l}\text { Tramiprosate } \\
\text { (small } \\
\text { aminosulphonate } \\
\text { compound) }\end{array}$ & Red marine algae & $50 \mathrm{mg} / \mathrm{kg}$ & $\begin{array}{l}\text { Intraluminal filament model of } \\
\text { MCAO }\end{array}$ & Reduces infarct volume & $\begin{array}{l}\text { PSD95/nNOS } \\
\text { signaling }\end{array}$ & $\begin{array}{l}\text { Disruption of the interaction } \\
\text { between PSD95 and nNOS; } \\
\downarrow \text { nNOS translocation }\end{array}$ & [191] \\
\hline Sulfated agaran & $\begin{array}{l}\text { Gracilaria cornea, } \\
\text { red alga }\end{array}$ & $\begin{array}{c}60 \mu \mathrm{g} \text {, single } \\
\text { intrastriatal injection }\end{array}$ & $\begin{array}{l}\text { Rat 6-hydroxydopamine } \\
\text { Parkinson's disease model }\end{array}$ & $\begin{array}{c}\downarrow \text { Oxidative/ } \\
\text { nitrosative stress; } \\
\text { restores behavioral } \\
\text { deficits and locomotor } \\
\text { performance; improves } \\
\text { weight }\end{array}$ & n.d. & $\begin{array}{c}\uparrow \mathrm{DA}, \mathrm{DOPAC} \text { and HVA; } \\
\downarrow 5-\mathrm{HT} ; \\
\downarrow \mathrm{NO} 2 / \mathrm{NO} 3 \text { and TBARS; } \\
\uparrow \mathrm{GSH} ; \\
\downarrow \text { p65, IL- } 1 \beta \text { and iNOS; } \\
\uparrow \mathrm{BDNF}\end{array}$ & [202] \\
\hline
\end{tabular}

n.d: not defined; -: information not available. 
Phloroglucinol also rescued the A $\beta 1-42$-induced reduction of dendritic spine density and synaptic protein (synaptophysin and postsynaptic density) levels in primary cultures of rat hippocampal neuronal [177]. Kang and co-investigators isolated five phlorotannins, such as phloroglucinol, eckol, triphloroethol A, eckstolonol, and dieckol from E. cava that attenuated $\mathrm{H}_{2} \mathrm{O}_{2}$-induced oxidative damage in HT22 hippocampus neurons by lowering ROS production, lipid peroxidation and $\mathrm{Ca}^{2+}$ release [178]. Phlorofucofuroeckol attenuated glutamate-induced cytotoxicity and improved mitochondrial dysfunction in PC12 cells [180]. Preconditioned HT22 hippocampal neurons with diphlorethohydroxycarmalol (DPHC), a phlorotannin of Ishige okamurae, was able to escape $\mathrm{H}_{2} \mathrm{O}_{2}$-induced oxidative damage due to antiapoptotic, pro-survival, and antioxidant potentials of DPHC [179]. Eckmaxol, a phlorotannin of Ecklonia maxima, reduced A $\beta$-oligomer-induced neuronal apoptosis in SH-SY5Y cells by inhibiting GSK-3 $\beta$ and ERK pathways [181,203].

Several studies have confirmed the neuroprotective capacity of algal polysaccharides, including fucoidan [204] and carrageenan. Fucoidan, a sulfated polysaccharide, attenuated $A \beta_{1-42}$-induced neurotoxicity in rat cholinergic basal forebrain neurons [182]. It restored $A \beta$-induced decline in whole-cell currents, increased phosphorylation of protein kinase C (PKC), and showed antioxidant and anti-apoptotic effects [182]. Fucoidan protected $\mathrm{H}_{2} \mathrm{O}_{2}$-induced cell death in PC-12 cells by activating the PI3K/Akt signaling pathway. The antioxidant, antiapoptotic, and prosurvival effects of fucoidan could explain its neuroprotection capacity [184]. Fucoidan protected against A $\beta 25-35$ and d-Gal-induced neurotoxicity in PC12 cells by reducing OS, suppressing apoptosis pathway, and promoting antioxidant defense [185]. Wu and colleagues reported that fucoidan suppressed intracellular $\mathrm{Ca}^{2+}$ responses by selective inhibition of N-methyl-D-aspartate (NMDA) receptors in cortical neurons and L-type $\mathrm{Ca}^{2+}$ channels in hippocampal neurons [187]. Three fucoidan extracts from Sargassum crassifolium attenuated $\mathrm{H}_{2} \mathrm{O}_{2}$-induced cytotoxicity in rat pheochromocytoma PC-12 cells [205]. In the $\mathrm{MPP}^{+} \mathrm{PD}$ model, fucoidan attenuated cytotoxicity in a dopaminergic neuronal precursor cell line (MN9D) $[183,186]$ by protecting lysosomes, reducing the expression of light chain 3-II (LC3-II), inhibiting the expression of cathepsin D (CatD)-Bax and the OS response [186]. Fucoidan of Sargassum hemiphyllum attenuated 6-hydroxydopamine-induced apoptosis in SH-SY5Y cells [206]. The acidic oligosaccharide sugar chain attenuated A $\beta$-stimulated astrocytes conditioned medium-induced cytotoxicity in SH-SY5Y cells by mitigating oxidative damage, reducing inflammatory response, and preventing $\mathrm{Ca}^{2+}$ influx [189]. In addition, $\mathrm{K}$-carrageenan-derived pentasaccharide (KCP) protected against A $325-35$-induced neurotoxicity in SH-SY5Y cells by regulating the c-Jun N-terminal kinase (JNK) signaling pathway [192]. Moreover, $\mathrm{k}$-carrageenan from Hypnea musciformis attenuated 6-hydroxydopamine-induced neurotoxicity on SH-SY5Y cells by modulation of the mitochondria transmembrane potential and reducing caspase 3 activity [207]. Oligo-porphyran (OP), an acid hydrolytic product of porphyran (a polysaccharide of Pyropia yezoensis) attenuated 6-OHDA-induced cytotoxicity in PC12 cells by activating PI3K/ Akt/PKC pathway that involved anti-apoptotic, antioxidant and anti-inflammatory signals [188].

Sargaquinoic acid identified from Sargassum macrocarpum promoted cell survival and neurite regeneration and attenuated $\mathrm{H}_{2} \mathrm{O}_{2}$-induced OS in PC12D cells [208]. Racemosin A, a bisindole alkaloid from Caulerpa racemose, attenuated A $325-35$-induced damage in SH-SY5Y cells [190]. Tramiprosate, a small aminosulphonate compound of red marine algae, attenuated OGD- or NMDA-induced injury in PC12 cells and primary cortical neurons [191] by disrupting the interaction between PSD95 and nNOS and inhibition of nNOS translocation [191]. Potentials of tramiprosate against AD and PD have also been reviewed elsewhere $[28,209,210]$. Dimethylsulfoniopropionate protected against tropodithietic acid-induced cytotoxicity in OLN-93 and N2a cells by lowering the activation of ERK1/2 and induction of HSP32 [149]. Phycoerythrin-derived peptide isolated from Pyropia yezoensis promoted survivability of frontal cortical neuron by activating TrkB receptor-ERK1/2 signaling and attenuating ER stress in rat prefrontal cortex [211] and attenuated glutamate-induced ER stress and senescence of rat primary hippocampal neurons [212]. Stearic acid from Caulerpa racemosa protected against OGD-induced 
SH-SY5Y cell damage while (8E)-heptadec-8-en-7-one showed moderate neuroprotective activity against A $325-35$-induced SHSY5Y cell damage [213].

In addition, extracts from several marine algae have shown neuroprotective activity in various in vitro models. The neuroprotective algae include Ulva conglobata that protected against glutamate-induced neurotoxicity in murine hippocampal HT22 cell line [108], Botryococcus braunii, and Nannochloropsis oculata against $\mathrm{H}_{2} \mathrm{O}_{2}$-induced cytotoxicity in dopaminergic SH-SY5Y cells [126], Padina pavonica, Sargassum muticum, Saccorhiza polyschides, Codium tomentosum, and Ulva compressa [214], and Bifurcaria bifurcata [215] against 6-hydroxidopamine-induced cytotoxicity in neuroblastoma cells, Cystoseira tamariscifolia and Cystoseira nodicaulis against $\mathrm{H}_{2} \mathrm{O}_{2}$-induced cytotoxicity in SH-SY5Y cells [127], Gracilaria corticata against aluminium-induced neurotoxicity in the hippocampus, and cerebral cortexes of rat brains [216], Australian macroalgae against A $\beta$ 1-42-induced neurotoxicity in PC-12 cells [217], Ishige foliacea against $\mathrm{H}_{2} \mathrm{O}_{2}$ - or A $\beta$-induced cell death in human neuroblastoma SH-SY5Y cells [128], Undaria pinnatifida against endoplasmic reticulum stress in hypothalamic neurons [218] and Gracilariopsis corda [219] and Gelidium amansii [153] against H/R-induced oxidative damage in primary hippocampal neurons, indicating that these algae could offer some potential compounds with encouraging neuroprotective activity, and, therefore, demand further investigation.

\section{Neuropharmacological Potentials of Marine Algae and Their Metabolites: Evidence from In Vivo Studies}

The neuroprotective effects of some potential algal compounds that were reported in the in vitro conditions have successfully been translated into animal models (Table 3), suggesting that these compounds could be potential candidates for further evaluation in the clinical trials.

Fucoidan is one of the algal compounds that has shown strong neuroprotection in several animal models. In the PD model of C57 / BL mice, fucoidan ameliorated MPTP-induced behavioral deficits, probably by elevating dopamine and its metabolite levels and increasing tyrosine hydroxylase expression [183]. In addition, fucoidan inhibited MPTP-induced lipid peroxidation and restored antioxidant capacity [183]. Similarly, fucoidan also improved behavioral capacity, by attenuating the loss of dopaminergic neurons and inhibited the deleterious activation of microglia in the substantia nigra pars compacta in LPS-induced neurotoxicity [93]. In an A $\beta$-induced rodent AD model, fucoidan ameliorated impaired memory, by reversing the decreased activity of ChAT, SOD, and GPx, increased activity of AChE, and rectifying the imbalance between apoptosis and pro-survival signals [193]. Fucoidan improved d-Gal-induced cognitive impairment in mice by mitigating OS and attenuating the caspase-dependent apoptosis pathway [185]. Wang and colleagues demonstrated that the supplementation of fucoidan alleviated $\mathrm{A} \beta$-induced paralyzed phenotype in a transgenic $C$. elegans $\mathrm{AD}$ model [194]. Fucoidan reduced A $\beta$ accumulation, probably by promoting proteasomal activity [194]. In another study, fucoidan-rich substances from Ecklonia cava improved trimethyltin-induced cognitive dysfunction by inhibiting $A \beta$ production and Tau hyperphosphorylation [195]. Fucoidan also attenuated transient global cerebral ischemic injury in the gerbil hippocampal CA1 area through mitigating glial activation and oxidative stress [196].

Laminarin, another polysaccharide of brown algae, has shown to protect $I / R$ injury in gerbil models. Intraperitoneal injection of laminarin $(50 \mathrm{mg} / \mathrm{kg}$ ) following $5 \mathrm{~min} \mathrm{I/R}$ attenuated reactive gliosis (anti-inflammatory) in the hippocampal CA1 of young gerbils [197]. A similar study following the same experimental protocol, but with aged gerbils, showed that laminarin (50 mg/kg) attenuated ischemia-induced death of pyramidal neurons in the hippocampal CA1 of aged gerbils [198]. This neuroprotective effect of laminarin is attributed to its antioxidant and anti-inflammatory properties [198]. Oligo-porphyran, a synthetic product of porphyran (Pyropia yezoensis) ameliorated behavioral deficits in 6-OHDA-induced Parkinsonian mice model by protecting dopaminergic loss and activating the PI3K/Akt/Bcl-2 pathway that involved cellular signaling of anti-apoptosis and antioxidation [199]. Zhang and colleagues demonstrated that porphyran from 
Pyropia haitanensis improved the A $\beta 1-40$-induced learning and memory deficits probably by elevating cerebral acetylcholine level [200].

Fucoxanthin is another significant algal metabolite that was found to be effective in a wide range of brain dysfunction (such as $\mathrm{AD}$, ischemic stroke, and traumatic brain injury). Fucoxanthin ameliorated scopolamine-induced [135] and A $\beta$ oligomer-induced [117] cognitive impairments in mice, possibly by inhibiting AChE activity and OS, modulating ChAT activity, and increasing BDNF expression. Fucoxanthin alleviated cerebral ischemic/reperfusion (I/R) injury, improved the neurologic deficit score, and downregulated the expression of apoptosis-linked proteins in brain samples [168]. Fucoxanthin also attenuated traumatic brain injury that involved the Nrf2-ARE and Nrf2-autophagy pathways-dependent neuroprotective mechanism [169].

Fucosterol co-infusion ameliorated sA $\beta 1$-42-induced cognitive deficits in aging rats by modulating BDNF signaling [172]. Dieckol and phlorofucofuroeckol raised the brain level of acetylcholine by inhibiting AChE and reduced the inhibition of latency in ethanol-intoxicated memory-impaired mice [120]. Yang and co-investigators demonstrated that stereotaxic injection of phloroglucinol promoted synaptic plasticity and improved memory impairment in 5XFAD (Tg6799) mice [177]. In a later study, the same group reported phloroglucinol (orally administered)-mediated amelioration of cognitive dysfunction that involved a reduction in the amyloid $\beta$ peptide burden and pro-inflammatory mediators and restoration of reduction in the dendritic spine density in the hippocampus of 5XFAD mice [220]. Phlorofucofuroeckol improved ischemic brain damage in the rat MCAO model [180]. C-Phycocyanin improved the functional outcome and survival of gerbils on global cerebral $\mathrm{I} / \mathrm{R}$ injury [201]. The in vitro neuroprotective effect of tramiprosate has been translated into in MCAO rat model in which it improved functional recovery following ischemic stroke [191]. Sulfated agaran, a sulfated polysaccharide from Gracilaria cornea, attenuated oxidative/nitrosative stress and ameliorates behavioral deficits in rat 6-hydroxydopamine Parkinson's disease model [202]. It raised levels of dopamine, 3,4-Dihydroxyphenylacetic acid (DOPAC), GSH, and BDNF, decreased serotonin (5-HT) and thiobarbituric acid reactive substances (TBARS) levels, and decreased the expression of p65, IL-1 $\beta$, and iNOS [202]. Glycoproteins isolated from Capsosiphon fulvescens ameliorated aging-induced spatial memory deficits by attenuating GSK-3 $\beta$-mediated ER stress in rat dorsal hippocampus [221] and promoted probiotics-induced cognitive improvement in aged rat model [222]. Gracilariopsis chorda and its active compound arachidonic acid, given independently through oral route for 10 days, improved scopolamine-induced memory impairment in mice [150].

In addition, extracts from several marine algae have shown to either ameliorate memory impairment or enhance cognition in various in vivo models. For instance, Gelidiella acerosa attenuated A $325-35$-induced cytotoxicity and memory deficits in mice [223], Sargassum swartzii improved memory functions in rats [224], Ishige foliacea [128], Undaria pinnatifida [225] ameliorated scopolamine-induced memory deficits in mice, Haematococcus pluvialis recovered Alzheimer's disease in rats [226], and fermented Spirulina maxima prevented memory impairment in mice [227]. In addition, some marine algae have shown to attenuate ischemic injury in stroke models. For example, Ecklonia cava ameliorated transient focal ischemia in the rat MCAO model [228].

\section{Recent Progress on the Development of Marine Algae-Based Neurotherapeutics}

An algal oligosaccharide, sodium oligomannate, recently received conditional approval in China for improving cognitive function in patients with mild to moderate AD [32]. In preclinical studies, sodium oligomannate conferred neuroprotection against $A \beta$-induced neurotoxicity in human neuroblastoma cells [229] and ameliorated memory dysfunction in the 5XFAD transgenic mouse model [230]. Sodium oligomannate can cross the blood-brain barrier through glucose transporter (GLUT1) and inhibits A $\beta$ fibril formation and destabilizes the preformed fibrils into nontoxic monomers [230]. Although the complete mechanism of pharmacological actions remains unclear, sodium oligomannate harnessed neuroinflammation and thus ameliorated memory impairment by suppressing gut dysbiosis and the associated phenylalanine/isoleucine accumulation [230]. In a phase IIa pilot study in patients 
with $\mathrm{AD}$, there was an elevation of $\mathrm{A} \beta 1-42$ levels in the cerebrospinal fluid (CSF) following sodium oligomannate treatment, suggesting a significant role in A $\beta$ clearance into CSF [231]. There was a differential reduction in the cerebral glucose metabolic rate (CMRglu) in various brain regions following sodium oligomannate in clinical trials [231]. While in a phase IIa trial, the CMRglu in left orbitofrontal gyrus, left precuneus, right posterior cingulate gyrus, and right hippocampus were found to be low, in a phase III trial, the lower rate was reported in superior parietal gyrus, inferior parietal gyrus, angular gyrus, and anterior wedge [232]. However, this newly approved drug lacks some advanced information like global data of effectivity and thus requires a large-scale global trial before it receives approval from the Food and Drug Administration (FDA).

\section{Algal Metabolites-Based Drug Discovery and Design}

While a significant quantity of active compounds has been isolated from marine algae and added to the compound databases [233-238] every year, it is disappointing that very few of them have access to clinical trial and the success rate is also not very satisfactory. In this context, the current strategy of drug development requires a reformation with the inclusion of some modern approaches, such as virtual screening and network pharmacology. The system biology approach along with an in silico study constitutes a potential computation tool that can better explain how a biologically effective compound interacts with the signal molecules of various cellular pathways.

Recent multitarget drugs have been designed by analyzing the 3D structure of already characterized compounds and crystal structure of target protein molecules. This information is focused on the virtual design of new chemical entities that include more than one biological function in a single molecule [239]. This approach is also known as target fishing, which identifies not only interacting proteins but also potential off-targets, and thus helps to understand polypharmacology, pharmacokinetics, and toxicity in the early stages of drug discovery [240]. For example, using in silico target fishing approach, Hannan and colleagues elucidated pharmacological mechanism of fucosterol-mediated neuroprotection and demonstrated that fucosterol showed interaction with potential targets, including LXR, TrkB, GR, Toll-like receptor (TLR) 2/4, and BACE1 [142]. Computational methods involving target screening are classified based on their principle including pharmacophore screening, shape screening, and reverse docking. When the target is available in the crystal structure, target fishing can be accomplished by a reverse docking approach, while, in the target's absence, pharmacophore or shape screening can be used to find the relevant target by comparing pharmacophoric feature or shape of the compound, taking information from protein-ligand binding databases [241]. In this effort, several natural product databases containing compound target interactomes are available nowadays including, SuperNatural [242], TCMID [243], TCMSP [244], and many others [245,246]; however, not many are dedicated to marine algae [233-235]. Although algal metabolites show structural diversity and redundancy, the mentioned databases could still be available for network pharmacology to get insight into the disease-modifying mechanisms. Following this in silico approach, Vitale et al. identified caulerpin as a PPAR agonist which was confirmed by both in vitro and in vivo assays [247]. In a reverse way, virtual screening through molecular docking analysis could be an alternative to find out potent hits from a large chemical library for a single target.

Compared to experimental high throughput screening, virtual screening, either by ligand or structure-based approach, can deliver the shorten cycle of hit discovery, with higher success hit rates. Furthermore, a structure-based approach consisting of molecular docking, receptor-based pharmacophore modeling together with molecular dynamics simulations and MM/PB(GB)SA approaches not only predict protein-ligand interaction but also provide a detailed binding mechanism, protein dynamics, and also highlight structure-activity relationship (SAR) for future drug design [248]. Several recent studies have been adopting molecular docking techniques to analyze detailed protein-ligand interaction for marine bioactive compounds. For example, Jung et al. employed molecular docking studies to predict comparative binding interaction of monoamine oxidase (MAO) with fucoxanthin, a carotenoid from Eisenia bicyclis, where they revealed fucoxanthin as a reversible 
competitive hMAO inhibitor, binding strongly to the enzyme, following hydrogen bonding and hydrophobic interactions [249]. A similar approach has been applied to elucidate the interaction of fucosterol and fucoxanthin with BACE1 while analyzing BACE1 enzyme inhibition by fucosterol and fucoxanthin. Here, binding interaction analysis by molecular docking identified that the presence of hydroxyl group in fucosterol and fucoxanthin is important for BACE1 inhibition, by which both compounds interacted with Lys224 residue, Gly11, and Ala127 of the active site, respectively [134]. Interestingly, fucoxanthin was also identified as a dopamine agonist, where a molecular docking study suggested that it formed H-bonding with Ser196 and Asp115 of the D4 receptor, and Ser196 and Thr115 residues of D3 receptors [250]. The same group also identified some bromophenols derivatives as D3R and $\mathrm{hD} 4 \mathrm{R}$ antagonists and studied the interaction and binding pattern by molecular docking [251].

In addition, several studies employed virtual screening to identify potent lead molecules from the database of seaweed metabolites. For instance, Florest et al. identified sigma-2 $\left(\sigma_{2}\right)$ receptor binding ligand by using both structure and ligand-based screening [252]. However, less effort has been deployed to develop marine natural product libraries, although significant studies so far have reported many compounds isolated from marine sources by large populations in the world. In this exertion, Davis et al. developed a chemical library of the natural compounds from marine algae, SWMD, comprised of 1110 metabolites, isolated from brown algae (266), green algae (33), and red algae (811) along with their physical and chemical properties [233]. Nevertheless, the information including experimentally-determined quantitative activity data and source information for more marine algal metabolites is still needed to facilitate computational based approaches in the exploration of marine compounds for future drug discovery.

\section{Safety Issues on Marine Algae-Derived Compounds}

As a popular food material in East Asian countries, including Japan, Korea and China, seaweed is consumed without reported toxicity. However, the concern is that seaweed may sometimes accumulate a considerable amount of heavy metals, such as cadmium, arsenic, mercury, and lead, and even some essential microelements such as iodine and iron [253]. It is, therefore, essential to conduct appropriate safety evaluations for seaweed. More importantly, while there are safety concerns during therapeutic development, the toxicity profile of seaweed-derived compounds needs to be thoroughly investigated. Safety information on algal metabolites is limited. However, toxicity profiles of algal polysaccharides have been reported by several studies. Observations from both in vitro and in vivo studies satisfied the non-toxic behavior of fucoidan irrespective of algal sources [254]. Fucoidan isolated from Undaria pinnatifida and Laminaria japonica was found to be safe in animal models given at very high oral doses [255-258]. Clinical studies also demonstrated the non-toxic health benefits of fucoidan in humans $[259,260]$. Safety evaluation studies on carrageenan suggest that sub-chronic or chronic feeding of this food-grade polysaccharide did not induce any toxic effects [261]. Moreover, dietary supplementation of carrageenan was not associated with carcinogenicity, genotoxicity, or reproductive defects [261]. Another study reported that no toxicological response was induced when iota-carrageenan was administered through the intranasal route [262]. Several studies also investigated toxicity of fucoxanthin and suggested that this carotenoid was safe and caused no visible toxicity in experimental subjects [263-265]. The toxicity profiles of some other marine metabolites have recently been reviewed [25]. As sufficient toxicological profiles of other potentially bioactive metabolites are lacking, they should be investigated with appropriate experimental models. 


\section{Conclusions and Future Perspectives}

The current review highlights several neuropharmacological attributes, such as antioxidant, anti-inflammatory, anti-cholinesterase, anti-amyloidogenic, antiaging, protein clearance, cholesterol homeostasis, and neuritogenic capacity of algae-derived metabolites that underlie their neuroprotective functions against a wide range of neurotoxic stimuli (Figure 5). The neuroprotective effects of marine algae and their metabolites do not necessarily depend on a single attribute, rather on the synergism of multiple of these pharmacological properties. As neurodegenerative disorders involve complex pathogenic mechanisms, they could be better managed with a single compound targeting two or more of the pathogenic mechanisms or multiple compounds with the complementary mechanism of action. In this context, algal compounds, such as fucoxanthin, fucosterol, and fucoidan that are known to target multiple pathogenic mechanisms could be potential candidates for future drug development. In addition, several metabolites, including laminarin, porphyran, saringasterol, $\alpha$-bisabolol, and phlorotannins that exhibited encouraging neuroprotective roles, also deserve further attention.

Although neuroactive compounds were isolated from a range of algae, seaweed species under Phaeophyceae yield the highest number of compounds. However, species from other groups, for example, Gelidium amansii under Rhodophyceae that exhibited significant neuromodulatory effects, also could offer some promising metabolites. Moreover, a large number of species remain unexplored. While degenerating brains experience disruption of synaptic connectivity, compounds with neuritogenic capacity may potentially enhance the regeneration of damaged processes. Therefore, compounds, both neuroprotective and neurotrophic, are equally important. However, in contrast to neuroprotective compounds that potentially support neuronal survival, a few compounds showing neurite outgrowth potential have been discovered in marine algae. Compounds, including those that have already shown neuroprotective ability as well as those that have not yet been explored, therefore, need to be screened for their ability to promote neurite extension.

Despite a sizable collection of algae-based natural products with distinct neuroprotective functions, only sodium oligomannate has emerged as a successful drug for AD. This review, therefore, calls for intensive research on other potential compounds to translate the preclinical findings into clinical models. In addition, the factors that are responsible for the failure of a clinical trial need to be carefully reviewed. For example, the bioavailability of a candidate drug in the brain, including its ability to cross BBB, remains one of the barriers to therapeutic success. If the ADME (absorption, distribution, metabolism, and excretion) properties of a preclinically effective compound sufficiently guarantee its drug-likeliness, it is highly likely that the compound may succeed in clinical trials. This is why the ongoing strategy requires a rational reformation incorporating modern approaches, such as virtual screening and system biology, to strengthen the algae-based drug development process. The computational study will provide some crucial information on the ADME properties of potential leads and its interaction and binding affinity to molecular targets while system biology knowledge will identify the potential interaction of target molecules and cellular signaling pathways at the systemic level. With the constant discovery of new compounds, all these strategies will accelerate the designing and development of algae-based future drugs. 


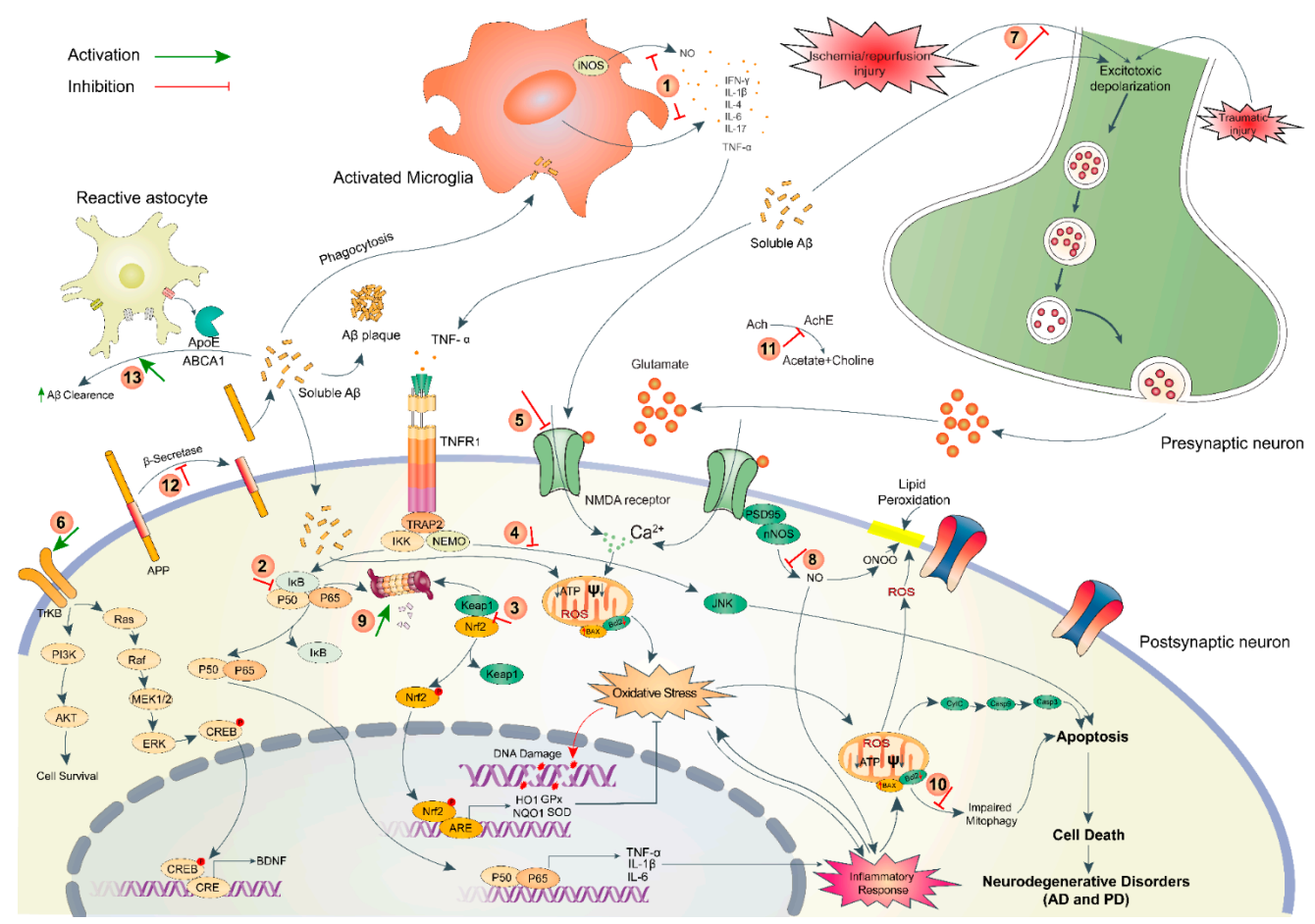

Figure 5. A scheme highlighting the pathophysiology of neurodegenerative disorders and post-ischemic consequences along with indicating the underlying mechanism of neuroprotective action of algal compounds. The numeric symbols indicate the points of pharmacological action that include (1) inhibition of cytokine secretion from activated microglia by fucoxanthin, fucosterol, fucoidan, dieckol, phlorofucofuroeckol and bieckol, $\mathrm{k}$-carrageenan, floridoside and seleno-polymannarate, (2) attenuation of inflammatory response via inhibition of NF-kB pathway by eckol, dieckol and 8,8-bieckol, (3) priming of antioxidant defense system via activation of Nrf2/ARE pathway (blocking interaction between Nrf2 and Keap1) by fucoxanthin, fucoidan and zonarol, (4) Reduction of apoptosis via inhibiting pro-apoptotic JNK/Erk pathway by dimethylsulfoniopropionate and $\mathrm{\kappa}$-carrageenan-derived pentasaccharide, (5) Inhibition of glutamate-induced Ca2+ influx via blocking extrasynaptic GluN2B by fucoidan and tramiprosate, (6) Activation of BDNF-dependent pro-survival pathway via inducing PI3K/Akt or TrkB/ERK signaling by fucoxanthin and fucosterol, (7) Attenuation of I/R-injury via preventing excitotoxic depolarization by C-phycocyanin, (8) Inhibition of $\mathrm{nNOS}$ sequestration by tramiprosate, (9) proteasomal degradation by fucoidan, (10) Induction of autophagy/mitophagy by fucoxanthin, (11) anticholinesterase activity by fucoidan, fucoxanthin, dieckol and phlorofucofuroeckol, (12) anti-amyloidogenesis via blocking $\beta$-secretase activity by fucoxanthin, fucosterol and glycoprotein, and (13) $A \beta$-clearance via enhancing the transcription of ApoE and $A B C$ transporters genes by fucosterol, saringasterol, and alginate-derived oligosaccharide. NF- $\mathrm{kB} / \mathrm{p} 50-\mathrm{pp} 65$, nuclear factor kappa-light-chain-enhancer of activated B cells; Nrf2, nuclear factor erythroid 2-related factor 2; ARE, antioxidant response element; IkB, inhibitor of NF-kB; Keap1, Kelch-like ECH-associated protein 1; JNK, c-Jun N-terminal kinases; GluN2B, N-methyl D-aspartate receptor subtype 2B; PI3K, phosphoinositide 3-kinases; Akt, protein kinase B; MEK1/2, mitogen-activated protein kinase kinase; ERK, extracellular signal-regulated kinases; TrkB, tropomyosin receptor kinase B; CREB, cAMP-response element binding protein; CRE, cAMP response elements; BDNF, Brain-derived neurotrophic factor; AChE, acetylcholinesterase; Ach, acetylcholine; ABCA1, ATP-binding cassette transporter A1; nNOS, neuronal nitric oxide synthase; ROS, reactive oxygen species; $\psi$, mitochondrial membrane potential.

Author Contributions: Conceptualization, M.A.H. and I.S.M.; Resources, M.A.H., R.D., A.A.M.S., M.N.H., M.M., M.A.R., M.A.; Writing-Original Draft Preparation, M.A.H., R.D., A.A.M.S., M.N.H., M.M., M.A.R.; Writing-Review and Editing, M.A.H., A.A.M.S., M.N.H., M.M., M.J.U.; Visualization, M.A.H., R.D. and M.A.; Supervision, I.S.M. All authors have read and agreed to the published version of the manuscript. 
Funding: Our research and publications have been supported by the Basic Science Research Program (\#2018R1A2B6002232 to I.S.M.) through the National Research Foundation of Korea (NRF) funded by the Ministry of Science, ICT and Future Planning. M.A.H. and M.A.R. wish to acknowledge the NRF for Korea Research Fellowship (\#2018H1D3A1A01074712 to M.A.H. and \#2016H1D3A1908615 to M.A.R) funded by the Ministry of Science, ICT and Future Planning. M.J.U. is supported by the RP-Grant 2020 of Ewha Womans University, Republic of Korea

Acknowledgments: This article is dedicated to Yong-Ki Hong, Professor of Biotechnology, Pukyong National University, Korea on the occasion of his retirement. Yong-Ki Hong has spent most of his academic and research career working on marine biotechnology, including the enrichment of macroalgae-based functional metabolites and the development of value-added products.

Conflicts of Interest: The authors declare no conflict of interest.

\section{References}

1. Chi, H.; Chang, H.Y.; Sang, T.K. Neuronal Cell Death Mechanisms in Major Neurodegenerative Diseases. Int. J. Mol. Sci. 2018, 19, 3082. [CrossRef]

2. Vasili, E.; Dominguez-Meijide, A.; Outeiro, T.F. Spreading of $\alpha$-Synuclein and Tau: A Systematic Comparison of the Mechanisms Involved. Front. Mol. Neurosci. 2019, 12, 107. [CrossRef]

3. Zhong, X.; Wang, J.; Carlsson, C.; Okonkwo, O.; Zetterberg, H.; Li, L. A Strategy for Discovery and Verification of Candidate Biomarkers in Cerebrospinal Fluid of Preclinical Alzheimer's Disease. Front. Mol. Neurosci. 2018, 11, 483. [CrossRef] [PubMed]

4. Ganguly, G.; Chakrabarti, S.; Chatterjee, U.; Saso, L. Proteinopathy, oxidative stress and mitochondrial dysfunction: Cross talk in Alzheimer's disease and Parkinson's disease. Drug Des. Dev. Ther. 2017, 11, 797-810. [CrossRef] [PubMed]

5. Verri, M.; Pastoris, O.; Dossena, M.; Aquilani, R.; Guerriero, F.; Cuzzoni, G.; Venturini, L.; Ricevuti, G.; Bongiorno, A.I. Mitochondrial Alterations, Oxidative Stress and Neuroinflammation in Alzheimer's Disease. Int. J. Immunopathol. Pharmacol. 2012, 25, 345-353. [CrossRef]

6. Jayaraj, R.L.; Azimullah, S.; Beiram, R.; Jalal, F.Y.; Rosenberg, G.A. Neuroinflammation: Friend and foe for ischemic stroke. J. Neuroinflamm. 2019, 16, 142. [CrossRef] [PubMed]

7. Islam, M.T. Oxidative stress and mitochondrial dysfunction-linked neurodegenerative disorders. Neurol. Res. 2017, 39, 73-82. [CrossRef]

8. Yahfoufi, N.; Alsadi, N.; Jambi, M.; Matar, C. The Immunomodulatory and Anti-Inflammatory Role of Polyphenols. Nutrients 2018, 10, 1618. [CrossRef] [PubMed]

9. Leon, R.; Garcia, A.G.; Marco-Contelles, J. Recent advances in the multitarget-directed ligands approach for the treatment of Alzheimer's disease. Med. Res. Rev. 2013, 33, 139-189. [CrossRef]

10. Angeloni, C.; Vauzour, D. Natural Products and Neuroprotection. Int. J. Mol. Sci. 2019, 20, 5570. [CrossRef] [PubMed]

11. Rehman, M.U.; Wali, A.F.; Ahmad, A.; Shakeel, S.; Rasool, S.; Ali, R.; Rashid, S.M.; Madkhali, H.; Ganaie, M.A.; Khan, R. Neuroprotective Strategies for Neurological Disorders by Natural Products: An update. Curr. Neuropharmacol. 2019, 17, 247-267. [CrossRef] [PubMed]

12. Kim, J.; Lee, H.J.; Lee, K.W. Naturally occurring phytochemicals for the prevention of Alzheimer's disease. J. Neurochem. 2010, 112, 1415-1430. [CrossRef]

13. Turner, R.S.; Thomas, R.G.; Craft, S.; van Dyck, C.H.; Mintzer, J.; Reynolds, B.A.; Brewer, J.B.; Rissman, R.A.; Raman, R.; Aisen, P.S. A randomized, double-blind, placebo-controlled trial of resveratrol for Alzheimer disease. Neurology 2015, 85, 1383-1391. [CrossRef] [PubMed]

14. Salehi, B.; Stojanović-Radić, Z.; Matejić, J.; Sharifi-Rad, M.; Anil Kumar, N.V.; Martins, N.; Sharifi-Rad, J. The therapeutic potential of curcumin: A review of clinical trials. Eur. J. Med. Chem. 2019, 163, 527-545. [CrossRef] [PubMed]

15. Leandro, A.; Pereira, L.; Gonçalves, A.M.M. Diverse Applications of Marine Macroalgae. Mar. Drugs 2020, 18, 17. [CrossRef] [PubMed]

16. Wells, M.L.; Potin, P.; Craigie, J.S.; Raven, J.A.; Merchant, S.S.; Helliwell, K.E.; Smith, A.G.; Camire, M.E.; Brawley, S.H. Algae as nutritional and functional food sources: Revisiting our understanding. J. Appl. Phycol. 2017, 29, 949-982. [CrossRef] 
17. Holdt, S.L.; Kraan, S. Bioactive compounds in seaweed: Functional food applications and legislation. J. Appl. Phycol. 2011, 23, 543-597. [CrossRef]

18. Peng, J.; Yuan, J.P.; Wu, C.F.; Wang, J.H. Fucoxanthin, a marine carotenoid present in brown seaweeds and diatoms: Metabolism and bioactivities relevant to human health. Mar. Drugs 2011, 9, 1806-1828. [CrossRef]

19. Salehi, B.; Sharifi-Rad, J.; Seca, A.M.L.; Pinto, D.C.G.A.; Michalak, I.; Trincone, A.; Mishra, A.P.; Nigam, M.; Zam, W.; Martins, N. Current Trends on Seaweeds: Looking at Chemical Composition, Phytopharmacology, and Cosmetic Applications. Molecules 2019, 24, 4182. [CrossRef]

20. Pangestuti, R.; Kim, S.K. Biological activities and health benefit effects of natural pigments derived from marine algae. J. Funct. Foods 2011, 3, 255-266. [CrossRef]

21. Alghazwi, M.; Kan, Y.Q.; Zhang, W.; Gai, W.P.; Garson, M.J.; Smid, S. Neuroprotective activities of natural products from marine macroalgae during 1999-2015. J. Appl. Phycol. 2016, 28, 3599-3616. [CrossRef]

22. Barbalace, M.C.; Malaguti, M.; Giusti, L.; Lucacchini, A.; Hrelia, S.; Angeloni, C. Anti-Inflammatory Activities of Marine Algae in Neurodegenerative Diseases. Int. J. Mol. Sci. 2019, 20, 3061. [CrossRef] [PubMed]

23. Barbosa, M.; Valentão, P.; Andrade, P.B. Bioactive compounds from macroalgae in the new millennium: Implications for neurodegenerative diseases. Mar. Drugs 2014, 12, 4934-4972. [CrossRef]

24. Cornish, M.L.; Critchley, A.T.; Mouritsen, O.G. Consumption of seaweeds and the human brain. J. Appl. Phycol. 2017, 29, 2377-2398. [CrossRef]

25. Rengasamy, K.R.R.; Mahomoodally, M.F.; Aumeeruddy, M.Z.; Zengin, G.; Xiao, J.; Kim, D.H. Bioactive compounds in seaweeds: An overview of their biological properties and safety. Food Chem. Toxicol. 2020, 135, 111013. [CrossRef]

26. Rajeswari, R.; Jeyaprakash, K. Biopotential effects of seaweeds for neurological disorders mini review. J. Pharm. Pharm. Sci. 2017, 6, 427-436.

27. Lauritzen, L.; Brambilla, P.; Mazzocchi, A.; Harsløf, L.B.S.; Ciappolino, V.; Agostoni, C. DHA Effects in Brain Development and Function. Nutrients 2016, 8, 6. [CrossRef]

28. Caltagirone, C.; Ferrannini, L.; Marchionni, N.; Nappi, G.; Scapagnini, G.; Trabucchi, M. The potential protective effect of tramiprosate (homotaurine) against Alzheimer's disease: A review. Aging Clin. Exp. Res. 2012, 24, 580-587.

29. Schepers, M.; Martens, N.; Tiane, A.; Vanbrabant, K.; Liu, H.B.; Lütjohann, D.; Mulder, M.; Vanmierlo, T. Edible seaweed-derived constituents: An undisclosed source of neuroprotective compounds. Neural Regen. Res. 2020, 15, 790-795.

30. Williams, L.L. Marine algae as a source of prevention and relief in those with depression and dementia. World J. Pharm. Pharm. Sci. 2017, 6, 26-38. [CrossRef]

31. Kim, S.K.; Pangestuti, R. Biological activities and potential health benefits of fucoxanthin derived from marine brown algae. Adv. Food Nutr. Res. 2011, 64, 111-128.

32. Syed, Y.Y. Sodium Oligomannate: First Approval. Drugs 2020, 80, 441-444. [CrossRef] [PubMed]

33. Pangestuti, R.; Kim, S.K. Neuroprotective effects of marine algae. Mar. Drugs 2011, 9, 803-818. [CrossRef]

34. Huang, C.; Zhang, Z.; Cui, W. Marine-Derived Natural Compounds for the Treatment of Parkinson's Disease. Mar. Drugs 2019, 17, 221. [CrossRef]

35. Olasehinde, T.A.; Olaniran, A.O.; Okoh, A.I. Macroalgae as a Valuable Source of Naturally Occurring Bioactive Compounds for the Treatment of Alzheimer's Disease. Mar. Drugs 2019, 17, 609. [CrossRef] [PubMed]

36. Pangestuti, R.; Vo, T.S.; Ngo, D.H.; Kim, S.K. Fucoxanthin Ameliorates Inflammation and Oxidative Reponses in Microglia. J. Agric. Food Chem. 2013, 61, 3876-3883. [CrossRef] [PubMed]

37. Hou, Y.; Dan, X.; Babbar, M.; Wei, Y.; Hasselbalch, S.G.; Croteau, D.L.; Bohr, V.A. Ageing as a risk factor for neurodegenerative disease. Nat. Rev. Neurol. 2019, 15, 565-581. [CrossRef]

38. Singh, A.; Kukreti, R.; Saso, L.; Kukreti, S. Oxidative Stress: A Key Modulator in Neurodegenerative Diseases. Molecules 2019, 24, 1583. [CrossRef] [PubMed]

39. Uddin, M.S.; Kabir, M.T.; Mamun, A.A.; Barreto, G.E.; Rashid, M.; Perveen, A.; Ashraf, G.M. Pharmacological approaches to mitigate neuroinflammation in Alzheimer's disease. Int. Immunopharmacol. 2020, 84, 106479. [CrossRef]

40. Hannan, M.A.; Dash, R.; Sohag, A.A.M.; Haque, M.N.; Moon, I.S. Neuroprotection against oxidative stress: Phytochemicals targeting TrkB signaling and the Nrf2-ARE antioxidant system. Front. Mol. Neurosci. 2020, 13,116 . 
41. Sivandzade, F.; Prasad, S.; Bhalerao, A.; Cucullo, L. NRF2 and NF-kB interplay in cerebrovascular and neurodegenerative disorders: Molecular mechanisms and possible therapeutic approaches. Redox Biol. 2019, 21, 101059. [CrossRef] [PubMed]

42. Castelli, V.; Benedetti, E.; Antonosante, A.; Catanesi, M.; Pitari, G.; Ippoliti, R.; Cimini, A.; d'Angelo, M. Neuronal Cells Rearrangement During Aging and Neurodegenerative Disease: Metabolism, Oxidative Stress and Organelles Dynamic. Front. Mol. Neurosci. 2019, 12, 132. [CrossRef] [PubMed]

43. Kandlur, A.; Satyamoorthy, K.; Gangadharan, G. Oxidative Stress in Cognitive and Epigenetic Aging: A Retrospective Glance. Front. Mol. Neurosci. 2020, 13, 41. [CrossRef]

44. Chaudhari, N.; Talwar, P.; Parimisetty, A.; Lefebvre d'Hellencourt, C.; Ravanan, P. A Molecular Web: Endoplasmic Reticulum Stress, Inflammation, and Oxidative Stress. Front. Mol. Neurosci. 2014, 8, 213. [CrossRef]

45. Gerakis, Y.; Hetz, C. Emerging roles of ER stress in the etiology and pathogenesis of Alzheimer's disease. FEBS J. 2018, 285, 995-1011. [CrossRef] [PubMed]

46. Guzman-Martinez, L.; Maccioni, R.B.; Andrade, V.; Navarrete, L.P.; Pastor, M.G.; Ramos-Escobar, N. Neuroinflammation as a Common Feature of Neurodegenerative Disorders. Front. Pharmacol. 2019, 10, 1008. [CrossRef]

47. Yanuck, S.F. Microglial Phagocytosis of Neurons: Diminishing Neuronal Loss in Traumatic, Infectious, Inflammatory, and Autoimmune CNS Disorders. Front. Psychiatry 2019, 10, 712. [CrossRef]

48. Sofroniew, M.V. Astrocyte barriers to neurotoxic inflammation. Nat. Rev. Neurosci. 2015, 16, $249-263$. [CrossRef]

49. Dash, R.; Mitra, S.; Ali, M.C.; Oktaviani, D.F.O.; Hannan, M.A.; Choi, S.M.; Moon, I.S. Phytosterols: Targeting Neuroinflammation in Neurodegeneration. Curr. Pharm. Des. 2020, 26, 1-23.

50. Liu, Z.; Zhou, T.; Ziegler, A.C.; Dimitrion, P.; Zuo, L. Oxidative Stress in Neurodegenerative Diseases: From Molecular Mechanisms to Clinical Applications. Oxid. Med. Cell. Longev. 2017, 2017, 2525967. [CrossRef]

51. Mouzat, K.; Chudinova, A.; Polge, A.; Kantar, J.; Camu, W.; Raoul, C.; Lumbroso, S. Regulation of Brain Cholesterol: What Role Do Liver X Receptors Play in Neurodegenerative Diseases? Int. J. Mol. Sci. 2019, 20, 3858. [CrossRef] [PubMed]

52. Ito, A.; Hong, C.; Rong, X.; Zhu, X.; Tarling, E.J.; Hedde, P.N.; Gratton, E.; Parks, J.; Tontonoz, P. LXRs link metabolism to inflammation through Abca1-dependent regulation of membrane composition and TLR signaling. eLife 2015, 4, e08009. [CrossRef]

53. Xu, P.; Li, D.; Tang, X.; Bao, X.; Huang, J.; Tang, Y.; Yang, Y.; Xu, H.; Fan, X. LXR agonists: New potential therapeutic drug for neurodegenerative diseases. Mol. Neurobiol. 2013, 48, 715-728. [CrossRef] [PubMed]

54. Dai, Y.B.; Tan, X.J.; Wu, W.F.; Warner, M.; Gustafsson, J.A. Liver X receptor beta protects dopaminergic neurons in a mouse model of Parkinson disease. Proc. Natl. Acad. Sci. USA 2012, 109, 13112-13117. [CrossRef] [PubMed]

55. Futter, M.; Diekmann, H.; Schoenmakers, E.; Sadiq, O.; Chatterjee, K.; Rubinsztein, D.C. Wild-type but not mutant huntingtin modulates the transcriptional activity of liver X receptors. J. Med. Genet. 2009, 46, 438-446. [CrossRef]

56. Wolf, A.; Bauer, B.; Hartz, A.M. ABC Transporters and the Alzheimer's Disease Enigma. Front. Psychiatry 2012, 3, 54. [CrossRef]

57. Campbell, B.C.V.; De Silva, D.A.; Macleod, M.R.; Coutts, S.B.; Schwamm, L.H.; Davis, S.M.; Donnan, G.A. Ischaemic stroke. Nat. Rev. Dis. Primers 2019, 5, 70. [CrossRef] [PubMed]

58. Soares, R.O.S.; Losada, D.M.; Jordani, M.C.; Évora, P.; Castroesilva, O. Ischemia/Reperfusion Injury Revisited: An Overview of the Latest Pharmacological Strategies. Int. J. Mol. Sci. 2019, 20, 5034. [CrossRef]

59. Wu, L.; Xiong, X.; Wu, X.; Ye, Y.; Jian, Z.; Zhi, Z.; Gu, L. Targeting Oxidative Stress and Inflammation to Prevent Ischemia-Reperfusion Injury. Front. Mol. Neurosci. 2020, 13, 28. [CrossRef]

60. Tschoe, C.; Bushnell, C.D.; Duncan, P.W.; Alexander-Miller, M.A.; Wolfe, S.Q. Neuroinflammation after Intracerebral Hemorrhage and Potential Therapeutic Targets. J. Stroke 2020, 22, 29-46. [CrossRef]

61. Liu, F.; Lu, J.; Manaenko, A.; Tang, J.; Hu, Q. Mitochondria in Ischemic Stroke: New Insight and Implications. Aging Dis. 2018, 9, 924-937. [CrossRef] [PubMed]

62. Yang, J.L.; Mukda, S.; Chen, S.D. Diverse roles of mitochondria in ischemic stroke. Redox Biol. 2018, 16, 263-275. [CrossRef] [PubMed] 
63. Gadani, S.P.; Walsh, J.T.; Lukens, J.R.; Kipnis, J. Dealing with Danger in the CNS: The Response of the Immune System to Injury. Neuron 2015, 87, 47-62. [CrossRef] [PubMed]

64. Mracsko, E.; Veltkamp, R. Neuroinflammation after intracerebral hemorrhage. Front. Cell. Neurosci. 2014, 8, 388. [CrossRef] [PubMed]

65. Malekahmadi, M.; Moradi Moghaddam, O.; Islam, S.M.S.; Tanha, K.; Nematy, M.; Pahlavani, N.; Firouzi, S.; Zali, M.R.; Norouzy, A. Evaluation of the effects of pycnogenol (French maritime pine bark extract) supplementation on inflammatory biomarkers and nutritional and clinical status in traumatic brain injury patients in an intensive care unit: A randomized clinical trial protocol. Trials 2020, 21, 162. [CrossRef]

66. Beauchamp, K.; Mutlak, H.; Smith, W.R.; Shohami, E.; Stahel, P.F. Pharmacology of traumatic brain injury: Where is the "golden bullet"? Mol. Med. 2008, 14, 731-740. [CrossRef]

67. Khatri, N.; Thakur, M.; Pareek, V.; Kumar, S.; Sharma, S.; Datusalia, A.K.J.C.; Targets, N.D.-D. Oxidative stress: Major threat in traumatic brain injury. CNS Neurol. Disord. Drug Targets 2018, 17, 689-695. [CrossRef] [PubMed]

68. Rodriguez-Rodriguez, A.; Jose Egea-Guerrero, J.; Murillo-Cabezas, F.; Carrillo-Vico, A. Oxidative stress in traumatic brain injury. Curr. Med. Chem. 2014, 21, 1201-1211. [CrossRef]

69. Heo, S.J.; Ko, S.C.; Kang, S.M.; Kang, H.S.; Kim, J.P.; Kim, S.H.; Lee, K.W.; Cho, M.G.; Jeon, Y.J. Cytoprotective effect of fucoxanthin isolated from brown algae Sargassum siliquastrum against $\mathrm{H}_{2} \mathrm{O}_{2}$-induced cell damage. Eur. Food Res. Technol. 2008, 228, 145-151. [CrossRef]

70. Zhao, D.; Kwon, S.H.; Chun, Y.S.; Gu, M.Y.; Yang, H.O. Anti-Neuroinflammatory Effects of Fucoxanthin via Inhibition of Akt/NF-kB and MAPKs/AP-1 Pathways and Activation of PKA/CREB Pathway in Lipopolysaccharide-Activated BV-2 Microglial Cells. Neurochem. Res. 2017, 42, 667-677. [CrossRef]

71. Lee, S.; Lee, Y.S.; Jung, S.H.; Kang, S.S.; Shin, K.H. Anti-oxidant activities of fucosterol from the marine algae Pelvetia siliquosa. Arch. Pharm. Res. 2003, 26, 719-722. [CrossRef]

72. Jung, H.A.; Jin, S.E.; Ahn, B.R.; Lee, C.M.; Choi, J.S. Anti-inflammatory activity of edible brown alga Eisenia bicyclis and its constituents fucosterol and phlorotannins in LPS-stimulated RAW264.7 macrophages. Food Chem. Toxicol. 2013, 59, 199-206. [CrossRef]

73. Choi, J.S.; Han, Y.R.; Byeon, J.S.; Choung, S.Y.; Sohn, H.S.; Jung, H.A. Protective effect of fucosterol isolated from the edible brown algae, Ecklonia stolonifera and Eisenia bicyclis, on tert-butyl hydroperoxide- and tacrine-induced HepG2 cell injury. J. Pharm. Pharmacol. 2015, 67, 1170-1178. [CrossRef]

74. Fernando, I.P.S.; Jayawardena, T.U.; Kim, H.S.; Lee, W.W.; Vaas, A.P.J.P.; De Silva, H.I.C.; Abayaweera, G.S.; Nanayakkara, C.M.; Abeytunga, D.T.U.; Lee, D.S.; et al. Beijing urban particulate matter-induced injury and inflammation in human lung epithelial cells and the protective effects of fucosterol from Sargassum binderi (Sonder ex J. Agardh). Environ. Res. 2019, 172, 150-158. [CrossRef]

75. Rafiquzzaman, S.M.; Kim, E.Y.; Lee, J.M.; Mohibbullah, M.; Alam, M.B.; Soo Moon, I.; Kim, J.M.; Kong, I.S. Anti-Alzheimers and anti-inflammatory activities of a glycoprotein purified from the edible brown alga Undaria pinnatifida. Food Res. Int. 2015, 77, 118-124. [CrossRef]

76. Zou, Y.; Qian, Z.J.; Li, Y.; Kim, M.M.; Lee, S.H.; Kim, S.K. Antioxidant Effects of Phlorotannins Isolated from Ishige okamurae in Free Radical Mediated Oxidative Systems. J. Agric. Food Chem. 2008, 56, 7001-7009. [CrossRef]

77. Zhang, Q.; Yu, P.; Li, Z.; Zhang, H.; Xu, Z.; Li, P. Antioxidant activities of sulfated polysaccharide fractions from Porphyra haitanesis. J. Appl. Phycol. 2003, 15, 305-310. [CrossRef]

78. Isaka, S.; Cho, K.; Nakazono, S.; Abu, R.; Ueno, M.; Kim, D.; Oda, T. Antioxidant and anti-inflammatory activities of porphyran isolated from discolored nori (Porphyra yezoensis). Int. J. Biol. Macromol. 2015, 74, 68-75. [CrossRef]

79. Anggadiredja, J.; Andyani, R.; Hayati, M. Antioxidant activity of Sargassum polycystum (Phaeophyta) and Laurencia obtusa (Rhodophyta) from Seribu Islands. J. Appl. Phycol. 1997, 9, 477. [CrossRef]

80. Rengasamy, K.R.R.; Amoo, S.O.; Aremu, A.O.; Stirk, W.A.; Gruz, J.; Šubrtová, M.; Doležal, K.; Van Staden, J. Phenolic profiles, antioxidant capacity, and acetylcholinesterase inhibitory activity of eight South African seaweeds. J. Appl. Phycol. 2015, 27, 1599-1605. [CrossRef]

81. Hannan, M.A.; Sohag, A.A.M.; Dash, R.; Haque, M.N.; Mohibbullah, M.; Oktaviani, D.F.; Hossain, M.T.; Choi, H.J.; Moon, I.S. Phytosterols of marine algae: Insights into the potential health benefits and molecular pharmacology. Phytomedicine 2020, 69, 153201. [CrossRef] 
82. Sun, Z.; Mohamed, M.A.A.; Park, S.Y.; Yi, T.H. Fucosterol protects cobalt chloride induced inflammation by the inhibition of hypoxia-inducible factor through PI3K/Akt pathway. Int. Immunopharmacol. 2015, 29, 642-647. [CrossRef] [PubMed]

83. Yoo, M.S.; Shin, J.S.; Choi, H.E.; Cho, Y.W.; Bang, M.H.; Baek, N.I.; Lee, K.T. Fucosterol isolated from Undaria pinnatifida inhibits lipopolysaccharide-induced production of nitric oxide and pro-inflammatory cytokines via the inactivation of nuclear factor-kappaB and p38 mitogen-activated protein kinase in RAW264.7 macrophages. Food Chem. 2012, 135, 967-975. [CrossRef] [PubMed]

84. Brandhorst, S.; Choi, I.Y.; Wei, M.; Cheng, C.W.; Sedrakyan, S.; Navarrete, G.; Dubeau, L.; Yap, L.P.; Park, R.; Vinciguerra, M.; et al. A Periodic Diet that Mimics Fasting Promotes Multi-System Regeneration, Enhanced Cognitive Performance, and Healthspan. Cell Metab. 2015, 22, 86-99. [CrossRef] [PubMed]

85. Wong, C.H.; Gan, S.Y.; Tan, S.C.; Gany, S.A.; Ying, T.; Gray, A.I.; Igoli, J.; Chan, E.W.L.; Phang, S.M. Fucosterol inhibits the cholinesterase activities and reduces the release of pro-inflammatory mediators in lipopolysaccharide and amyloid-induced microglial cells. J. Appl. Phycol. 2018, 30, 3261-3270. [CrossRef]

86. Jung, W.K.; Heo, S.J.; Jeon, Y.J.; Lee, C.M.; Park, Y.M.; Byun, H.G.; Choi, Y.H.; Park, S.G.; Choi, I.W. Inhibitory effects and molecular mechanism of dieckol isolated from marine brown alga on COX-2 and iNOS in microglial cells. J. Agric. Food Chem. 2009, 57, 4439-4446. [CrossRef]

87. Kim, A.R.; Lee, M.S.; Choi, J.W.; Utsuki, T.; Kim, J.I.; Jang, B.C.; Kim, H.R. Phlorofucofuroeckol A suppresses expression of inducible nitric oxide synthase, cyclooxygenase-2, and pro-inflammatory cytokines via inhibition of nuclear factor- $\mathrm{BB}, \mathrm{c}-J u n \mathrm{NH} 2$-terminal kinases, and Akt in microglial cells. Inflammation 2013, 36, 259-271. [CrossRef]

88. Yu, D.K.; Lee, B.; Kwon, M.; Yoon, N.; Shin, T.; Kim, N.G.; Choi, J.S.; Kim, H.R. Phlorofucofuroeckol B suppresses inflammatory responses by down-regulating nuclear factor $\mathrm{\kappa B}$ activation via Akt, ERK, and JNK in LPS-stimulated microglial cells. Int. Immunopharmacol. 2015, 28, 1068-1075. [CrossRef]

89. Kim, A.R.; Lee, B.; Joung, E.J.; Gwon, W.G.; Utsuki, T.; Kim, N.G.; Kim, H.R. 6,6'-Bieckol suppresses inflammatory responses by down-regulating nuclear factor- $\mathrm{kB}$ activation via Akt, JNK, and p38 MAPK in LPS-stimulated microglial cells. Immunopharmacol. Immunotoxicol. 2016, 38, 244-252. [CrossRef] [PubMed]

90. Yang, Y.I.; Jung, S.H.; Lee, K.T.; Choi, J.H. 8,8'-Bieckol, isolated from edible brown algae, exerts its anti-inflammatory effects through inhibition of NF- $\mathrm{KB}$ signaling and ROS production in LPS-stimulated macrophages. Int. Immunopharmacol. 2014, 23, 460-468. [CrossRef]

91. Florez, N.; Gonzalez-Munoz, M.J.; Ribeiro, D.; Fernandes, E.; Dominguez, H.; Freitas, M. Algae Polysaccharides' Chemical Characterization and their Role in the Inflammatory Process. Curr. Med. Chem. 2017, 24, 149-175. [CrossRef] [PubMed]

92. Park, H.Y.; Han, M.H.; Park, C.; Jin, C.Y.; Kim, G.Y.; Choi, I.W.; Kim, N.D.; Nam, T.J.; Kwon, T.K.; Choi, Y.H. Anti-inflammatory effects of fucoidan through inhibition of NF-kB, MAPK and Akt activation in lipopolysaccharide-induced BV2 microglia cells. Food Chem. Toxicol. 2011, 49, 1745-1752. [CrossRef] [PubMed]

93. Cui, Y.Q.; Jia, Y.J.; Zhang, T.; Zhang, Q.B.; Wang, X.M. Fucoidan Protects against Lipopolysaccharide-Induced Rat Neuronal Damage and Inhibits the Production of Proinflammatory Mediators in Primary Microglia. CNS Neurosci. Ther. 2012, 18, 827-833. [CrossRef] [PubMed]

94. Yao, Z.A.; Xu, L.; Wu, H.G. Immunomodulatory function of $\mathrm{k}$-carrageenan oligosaccharides acting on LPS-activated microglial cells. Neurochem. Res. 2014, 39, 333-343. [CrossRef]

95. Jiang, Z.; Hama, Y.; Yamaguchi, K.; Oda, T. Inhibitory effect of sulphated polysaccharide porphyran on nitric oxide production in lipopolysaccharide-stimulated RAW264.7 macrophages. J. Biochem. 2012, 151, 65-74. [CrossRef]

96. Liu, X.Y.; Liu, D.; Lin, G.P.; Wu, Y.J.; Gao, L.Y.; Ai, C.; Huang, Y.F.; Wang, M.F.; El-Seedi, H.R.; Chen, X.H.; et al. Anti-ageing and antioxidant effects of sulfate oligosaccharides from green algae Ulva lactuca and Enteromorpha prolifera in SAMP8 mice. Int. J. Biol. Macromol. 2019, 139, 342-351. [CrossRef]

97. Zhou, R.; Shi, X.Y.; Bi, D.C.; Fang, W.S.; Wei, G.B.; Xu, X. Alginate-Derived Oligosaccharide Inhibits Neuroinflammation and Promotes Microglial Phagocytosis of $\beta$-Amyloid. Mar. Drugs 2015, 13, 5828-5846. [CrossRef]

98. Bi, D.; Lai, Q.; Han, Q.; Cai, N.; He, H.; Fang, W.; Yi, J.; Li, X.; Xu, H.; Li, X.; et al. Seleno-polymannuronate attenuates neuroinflammation by suppressing microglial and astrocytic activation. J. Funct. Foods 2018, 51, 113-120. [CrossRef] 
99. Yang, E.J.; Ham, Y.M.; Yang, K.W.; Lee, N.H.; Hyun, C.G. Sargachromenol from Sargassum micracanthum inhibits the lipopolysaccharide-induced production of inflammatory mediators in RAW 264.7 macrophages. Sci. World J. 2013, 2013, 712303. [CrossRef]

100. Kang, G.J.; Han, S.C.; Yoon, W.J.; Koh, Y.S.; Hyun, J.W.; Kang, H.K.; Youl Cho, J.; Yoo, E.S. Sargaquinoic acid isolated from Sargassum siliquastrum inhibits lipopolysaccharide-induced nitric oxide production in macrophages via modulation of nuclear factor- $\kappa \mathrm{B}$ and c-Jun $\mathrm{N}$-terminal kinase pathways. Immunopharm. Immunot. 2013, 35, 80-87. [CrossRef]

101. Kim, M.; Li, Y.X.; Dewapriya, P.; Ryu, B.; Kim, S.K. Floridoside suppresses pro-inflammatory responses by blocking MAPK signaling in activated microglia. BMB Rep. 2013, 46, 398-403. [CrossRef] [PubMed]

102. Souza, C.R.M.; Bezerra, W.P.; Souto, J.T. Marine Alkaloids with Anti-Inflammatory Activity: Current Knowledge and Future Perspectives. Mar. Drugs 2020, 18, 147. [CrossRef] [PubMed]

103. Jung, W.K.; Ahn, Y.W.; Lee, S.H.; Choi, Y.H.; Kim, S.K.; Yea, S.S.; Choi, I.; Park, S.G.; Seo, S.K.; Lee, S.W.; et al. Ecklonia cava ethanolic extracts inhibit lipopolysaccharide-induced cyclooxygenase-2 and inducible nitric oxide synthase expression in BV2 microglia via the MAP kinase and NF-kappaB pathways. Food Chem. Toxicol. 2009, 47, 410-417. [CrossRef] [PubMed]

104. Kim, S.; Kim, J.I.; Choi, J.W.; Kim, M.; Yoon, N.Y.; Choi, C.G.; Choi, J.S.; Kim, H.R. Anti-inflammatory effect of hexane fraction from Myagropsis myagroides ethanolic extract in lipopolysaccharide-stimulated BV-2 microglial cells. J. Pharm. Pharmacol. 2013, 65, 895-906. [CrossRef]

105. Kim, S.; Lee, M.S.; Lee, B.; Gwon, W.G.; Joung, E.J.; Yoon, N.Y.; Kim, H.R. Anti-inflammatory effects of sargachromenol-rich ethanolic extract of Myagropsis myagroides on lipopolysaccharide-stimulated BV-2 cells. BMC Complement. Altern. Med. 2014, 14, 231. [CrossRef] [PubMed]

106. Oh, S.J.; Joung, E.J.; Kwon, M.S.; Lee, B.; Utsuki, T.; Oh, C.W.; Kim, H.R. Anti-Inflammatory Effect of Ethanolic Extract of Sargassum serratifolium in Lipopolysaccharide-Stimulated BV2 Microglial Cells. J. Med. Food 2016, 19, 1023-1031. [CrossRef]

107. Gany, S.A.; Tan, S.C.; Gan, S.Y. Antioxidative, anticholinesterase and anti-neuroinflammatory properties of Malaysian brown and green seaweeds. World Acad. Sci. Eng. Technol. 2015, 8, 1269-1275.

108. Jin, D.Q.; Lim, C.S.; Sung, J.Y.; Choi, H.G.; Ha, I.; Han, J.S. Ulva conglobata, a marine algae, has neuroprotective and anti-inflammatory effects in murine hippocampal and microglial cells. Neurosci. Lett. 2006, 402, 154-158. [CrossRef]

109. Gwon, W.G.; Lee, M.S.; Kim, J.S.; Kim, J.I.; Lim, C.W.; Kim, N.G.; Kim, H.R. Hexane fraction from Sargassum fulvellum inhibits lipopolysaccharide-induced inducible nitric oxide synthase expression in RAW 264.7 cells via NF-kB pathways. Am. J. Chin. Med. 2013, 41, 565-584. [CrossRef] [PubMed]

110. Kim, M.E.; Jung, Y.C.; Jung, I.; Lee, H.W.; Youn, H.Y.; Lee, J.S. Anti-inflammatory effects of ethanolic extract from Sargassum horneri (Turner) C. Agardh on lipopolysaccharide-stimulated macrophage activation via NF-kB pathway regulation. Immunol. Investig. 2015, 44, 137-146. [CrossRef]

111. Joung, E.J.; Lee, M.S.; Choi, J.W.; Kim, J.S.; Shin, T.; Jung, B.M.; Yoon, N.Y.; Lim, C.W.; Kim, J.I.; Kim, H.R. Anti-inflammatory effect of ethanolic extract from Myagropsis myagroides on murine macrophages and mouse ear edema. BMC Complement. Altern. Med. 2012, 12, 171. [CrossRef] [PubMed]

112. Joung, E.J.; Lee, M.S.; Choi, J.W.; Kim, J.S.; Shin, T.; Jung, B.M.; Kim, J.I.; Kim, H.R. Anti-inflammatory effects of phlorofucofuroeckol B-rich ethyl acetate fraction obtained from Myagropsis myagroides on lipopolysaccharide-stimulated RAW 264.7 cells and mouse edema. Int. Immunopharmacol. 2012, 14, 471-480. [CrossRef] [PubMed]

113. Joung, E.J.; Gwon, W.G.; Shin, T.; Jung, B.M.; Choi, J.; Kim, H.R. Anti-inflammatory action of the ethanolic extract from Sargassum serratifolium on lipopolysaccharide-stimulated mouse peritoneal macrophages and identification of active components. J. Appl. Phycol. 2017, 29, 563-573. [CrossRef]

114. Yoon, N.Y.; Chung, H.Y.; Kim, H.R.; Choi, J.S. Acetyl- and butyrylcholinesterase inhibitory activities of sterols and phlorotannins from Ecklonia stolonifera. Fish. Res. 2008, 74, 200-207. [CrossRef]

115. Castro-Silva, E.S.; Bello, M.; Hernandez-Rodriguez, M.; Correa-Basurto, J.; Murillo-Alvarez, J.I.; Rosales-Hernandez, M.C.; Munoz-Ochoa, M. In vitro and in silico evaluation of fucosterol from Sargassum horridum as potential human acetylcholinesterase inhibitor. J. Biomol. Struct. Dyn. 2019, 37, 3259-3268. [CrossRef]

116. Kawee-ai, A.; Kuntiya, A.; Kim, S.M. Anticholinesterase and antioxidant activities of fucoxanthin purified from the microalga Phaeodactylum tricornutum. Nat. Prod. Commun. 2013, 8, 1381-1386. [CrossRef] 
117. Lin, J.; Huang, L.; Yu, J.; Xiang, S.; Wang, J.; Zhang, J.; Yan, X.; Cui, W.; He, S.; Wang, Q. Fucoxanthin, a Marine Carotenoid, Reverses Scopolamine-Induced Cognitive Impairments in Mice and Inhibits Acetylcholinesterase in vitro. Mar. Drugs 2016, 14, 67. [CrossRef]

118. Shanmuganathan, B.; Sheeja Malar, D.; Sathya, S.; Pandima Devi, K. Antiaggregation Potential of Padina gymnospora against the Toxic Alzheimer's Beta-Amyloid Peptide 25-35 and Cholinesterase Inhibitory Property of Its Bioactive Compounds. PLoS ONE 2015, 10, e0141708. [CrossRef]

119. Kannan, R.R.R.; Aderogba, M.A.; Ndhlala, A.R.; Stirk, W.A.; Van Staden, J. Acetylcholinesterase inhibitory activity of phlorotannins isolated from the brown alga, Ecklonia maxima (Osbeck) Papenfuss. Food Res. Int. 2013, 54, 1250-1254. [CrossRef]

120. Myung, C.S.; Shin, H.C.; Bao, H.Y.; Yeo, S.J.; Lee, B.H.; Kang, J.S. Improvement of memory by dieckol and phlorofucofuroeckol in ethanol-treated mice: Possible involvement of the inhibition of acetylcholinesterase. Arch. Pharm. Res. 2005, 28, 691-698. [CrossRef]

121. Choi, B.W.; Ryu, G.; Park, S.H.; Kim, E.S.; Shin, J.; Roh, S.S.; Shin, H.C.; Lee, B.H. Anticholinesterase activity of plastoquinones from Sargassum sagamianum: Lead compounds for Alzheimer's disease therapy. Phytother. Res. 2007, 21, 423-426. [CrossRef]

122. Rengasamy, K.R.R.; Aderogba, M.A.; Amoo, S.O.; Stirk, W.A.; Van Staden, J. Macrocystis angustifolia is a potential source of enzyme inhibitors linked to type 2 diabetes and dementia. J. Appl. Phycol. 2014, 26, 1557-1563. [CrossRef]

123. Seong, S.H.; Ali, M.Y.; Kim, H.R.; Jung, H.A.; Choi, J.S. BACE1 inhibitory activity and molecular docking analysis of meroterpenoids from Sargassum serratifolium. Bioorg. Med. Chem. 2017, 25, 3964-3970. [CrossRef] [PubMed]

124. Lee, J.; Jun, M. Dual BACE1 and Cholinesterase Inhibitory Effects of Phlorotannins from Ecklonia cava-An In Vitro and in Silico Study. Mar. Drugs 2019, 17, 91. [CrossRef]

125. Murugan, A.C.; Vallal, D.; Karim, M.R.; Govindan, N.; Yusoff, M.; Rahman, M.J. In vitro antiradical and neuroprotective activity of polyphenolic extract from marine algae Padina australis H. J. Chem. Pharm. Res. 2015, 7, 355-362.

126. Custódio, L.; Soares, F.; Pereira, H.; Rodrigues, M.J.; Barreira, L.; Rauter, A.P.; Alberício, F.; Varela, J. Botryococcus braunii and Nannochloropsis oculata extracts inhibit cholinesterases and protect human dopaminergic SH-SY5Y cells from $\mathrm{H}_{2} \mathrm{O}_{2}$-induced cytotoxicity. J. Appl. Phycol. 2015, 27, 839-848. [CrossRef]

127. Custódio, L.; Silvestre, L.; Rocha, M.I.; Rodrigues, M.J.; Vizetto-Duarte, C.; Pereira, H.; Barreira, L.; Varela, J. Methanol extracts from Cystoseira tamariscifolia and Cystoseira nodicaulis are able to inhibit cholinesterases and protect a human dopaminergic cell line from hydrogen peroxide-induced cytotoxicity. Pharm. Biol. 2016, 54, 1687-1696. [CrossRef] [PubMed]

128. Kim, T.E.; Son, H.J.; Lim, D.W.; Yoon, M.; Lee, J.; Kim, Y.T.; Han, D.; Lee, C.; Um, M.Y. Memory-enhancing effects of Ishige foliacea extract: In vitro and in vivo study. J. Food Biochem. 2020, 44, e13162. [CrossRef]

129. Nunes, N.; Rosa, G.P.; Ferraz, S.; Barreto, M.C.; de Carvalho, M.A.A.P. Fatty acid composition, TLC screening, ATR-FTIR analysis, anti-cholinesterase activity, and in vitro cytotoxicity to A549 tumor cell line of extracts of 3 macroalgae collected in Madeira. J. Appl. Phycol. 2019. [CrossRef]

130. De Souza, E.T.; de Lira, D.P.; de Queiroz, A.C.; da Silva, D.J.C.; de Aquino, A.B.; Mella, E.A.C.; Lorenzo, V.P.; de Miranda, G.E.C.; de Araújo-Júnior, J.X.; de Oliveira Chaves, M.C.; et al. The antinociceptive and anti-inflammatory activities of caulerpin, a bisindole alkaloid isolated from seaweeds of the genus Caulerpa. Mar. Drugs 2009, 7, 689-704. [CrossRef] [PubMed]

131. Cengiz, S.; Cavas, L.; Yurdakoc, K.; Pohnert, G. The Sesquiterpene Caulerpenyne from Caulerpa spp. is a Lipoxygenase Inhibitor. Mar. Biotechnol. 2011, 13, 321-326. [CrossRef] [PubMed]

132. Ryan, S.; O'Gorman, D.M.; Nolan, Y.M. Evidence that the marine-derived multi-mineral Aquamin has anti-inflammatory effects on cortical glial-enriched cultures. Phytother. Res. 2011, 25, 765-767. [CrossRef] [PubMed]

133. Ryu, G.; Park, S.H.; Kim, E.S.; Choi, B.W.; Ryu, S.Y.; Lee, B.H. Cholinesterase inhibitory activity of two farnesylacetone derivatives from the brown alga Sargassum sagamianum. Arch. Pharm. Res. 2003, 26, 796-799. [CrossRef] [PubMed]

134. Jung, H.A.; Ali, M.Y.; Choi, R.J.; Jeong, H.O.; Chung, H.Y.; Choi, J.S. Kinetics and molecular docking studies of fucosterol and fucoxanthin, BACE1 inhibitors from brown algae Undaria pinnatifida and Ecklonia stolonifera. Food Chem. Toxicol. 2016, 89, 104-111. [CrossRef] 
135. Xiang, S.; Liu, F.; Lin, J.; Chen, H.; Huang, C.; Chen, L.; Zhou, Y.; Ye, L.; Zhang, K.; Jin, J.; et al. Fucoxanthin Inhibits $\beta$-Amyloid Assembly and Attenuates $\beta$-Amyloid Oligomer-Induced Cognitive Impairments. J. Agric. Food Chem. 2017, 65, 4092-4102. [CrossRef]

136. Alghazwi, M.; Smid, S.; Musgrave, I.; Zhang, W. In vitro studies of the neuroprotective activities of astaxanthin and fucoxanthin against amyloid beta $(\mathrm{A} \beta(1-42))$ toxicity and aggregation. Neurochem. Int. 2019, 124, $215-224$. [CrossRef]

137. Shanmuganathan, B.; Suryanarayanan, V.; Sathya, S.; Narenkumar, M.; Singh, S.K.; Ruckmani, K.; Pandima Devi, K. Anti-amyloidogenic and anti-apoptotic effect of $\alpha$-bisabolol against $A \beta$ induced neurotoxicity in PC12 cells. Eur. J. Med. Chem. 2018, 143, 1196-1207. [CrossRef]

138. Hoang, M.H.; Jia, Y.; Jun, H.J.; Lee, J.H.; Lee, B.Y.; Lee, S.J. Fucosterol Is a Selective Liver X Receptor Modulator That Regulates the Expression of Key Genes in Cholesterol Homeostasis in Macrophages, Hepatocytes, and Intestinal Cells. J. Agric. Food Chem. 2012, 60, 11567-11575. [CrossRef]

139. Chen, Z.; Liu, J.; Fu, Z.; Ye, C.; Zhang, R.; Song, Y.; Zhang, Y.; Li, H.; Ying, H.; Liu, H. 24(S)-Saringosterol from edible marine seaweed Sargassum fusiforme is a novel selective LXRbeta agonist. J. Agric. Food Chem. 2014, 62, 6130-6137. [CrossRef]

140. Seong, S.H.; Paudel, P.; Choi, J.W.; Ahn, D.H.; Nam, T.J.; Jung, H.A.; Choi, J.S. Probing multi-target action of phlorotannins as new monoamine oxidase inhibitors and dopaminergic receptor modulators with the potential for treatment of neuronal disorders. Mar. Drugs 2019, 17, 377. [CrossRef]

141. Oktaviani, D.F.; Bae, Y.S.; Meinita, M.D.N.; Moon, I.S.; Hong, Y.K. An ethanol extract of the brown seaweed Hizikia fusiformis and its active constituent, fucosterol, extend the lifespan of the nematode Caenorhabditis elegans. J. Life Sci. 2019, 29, 1120-1125.

142. Hannan, M.A.; Dash, R.; Sohag, A.A.M.; Moon, I.S. Deciphering molecular mechanism of the neuropharmacological action of fucosterol through integrated system pharmacology and in silico analysis. Mar. Drug 2019, 17, 639. [CrossRef]

143. Dezsi, L.; Vecsei, L. Monoamine Oxidase B Inhibitors in Parkinson's Disease. CNS Neurol. Disord. DrugTargets 2017, 16, 425-439. [CrossRef] [PubMed]

144. Abdul, Q.A.; Choi, R.J.; Jung, H.A.; Choi, J.S. Health benefit of fucosterol from marine algae: A review. J. Sci. Food Agric. 2016, 96, 1856-1866. [CrossRef] [PubMed]

145. Tsang, C.K.; Ina, A.; Goto, T.; Kamei, Y. Sargachromenol, a novel nerve growth factor-potentiating substance isolated from Sargassum macrocarpum, promotes neurite outgrowth and survival via distinct signaling pathways in PC12D cells. Neuroscience 2005, 132, 633-643. [CrossRef]

146. Kamei, Y.; Tsang, C.K. Sargaquinoic acid promotes neurite outgrowth via protein kinase A and MAP kinases-mediated signaling pathways in PC12D cells. Int. J. Dev. Neurosci. 2003, 21, 255-262. [CrossRef]

147. Ina, A.; Hayashi, K.I.; Nozaki, H.; Kamei, Y. Pheophytin a, a low molecular weight compound found in the marine brown alga Sargassum fulvellum, promotes the differentiation of PC12 cells. Int. J. Dev. Neurosci. 2007, 25, 63-68. [CrossRef]

148. Ina, A.; Kamei, Y. Vitamin B(12), a chlorophyll-related analog to pheophytin a from marine brown algae, promotes neurite outgrowth and stimulates differentiation in PC12 cells. Cytotechnology 2006, 52, 181-187. [CrossRef]

149. Wichmann, H.; Brinkhoff, T.; Simon, M.; Richter-Landsberg, C. Dimethylsulfoniopropionate promotes process outgrowth in neural cells and exerts protective effects against tropodithietic acid. Mar. Drugs 2016, 14, 89. [CrossRef]

150. Mohibbullah, M.; Choi, J.S.; Bhuiyan, M.M.H.; Haque, M.N.; Rahman, M.K.; Moon, I.S.; Hong, Y.K. The red alga Gracilariopsis chorda and its active constituent arachidonic acid promote spine dynamics via dendritic filopodia and potentiate functional synaptic plasticity in hippocampal neurons. J. Med. Food 2018, 21, 481-488. [CrossRef]

151. Kamei, Y.; Sagara, A. Neurite outgrowth promoting activity of marine algae from Japan against rat adrenal medulla pheochromocytoma cell line, PC12D. Cytotechnology 2002, 40, 99-106. [CrossRef] [PubMed]

152. Mohibbullah, M.; Bhuiyan, M.M.; Hannan, M.A.; Getachew, P.; Hong, Y.K.; Choi, J.S.; Choi, I.S.; Moon, I.S. The Edible Red alga Porphyra yezoensis promotes neuronal survival and cytoarchitecture in primary hippocampal neurons. Cell. Mol. Neurobiol. 2016, 36, 669-682. [CrossRef] [PubMed] 
153. Hannan, M.A.; Haque, M.N.; Mohibbullah, M.; Dash, R.; Hong, Y.K.; Moon, I.S. Gelidium amansii Attenuates hypoxia/reoxygenation-induced oxidative injury in primary hippocampal neurons through suppressing glun2b expression. Antioxidants 2020, 9, 223. [CrossRef] [PubMed]

154. Hannan, M.A.; Mohibbullah, M.; Hong, Y.K.; Moon, I.S. Proteomic analysis of the neurotrophic effect of Gelidium amansii in primary cultured neurons. J. Med. Food 2017, 20, 279-287. [CrossRef] [PubMed]

155. Hannan, M.A.; Kang, J.Y.; Hong, Y.K.; Lee, H.; Choi, J.S.; Choi, I.S.; Moon, I.S. The marine alga Gelidium amansii promotes the development and complexity of neuronal cytoarchitecture. Phytother. Res. 2013, 27, 21-29. [CrossRef] [PubMed]

156. Hannan, M.A.; Mohibbullah, M.; Hong, Y.K.; Nam, J.H.; Moon, I.S. Gelidium amansii promotes dendritic spine morphology and synaptogenesis, and modulates NMDA receptor-mediated postsynaptic current. In Vitro Cell. Dev. Biol. Anim. 2014, 50, 445-452. [CrossRef]

157. Hannan, M.A.; Kang, J.Y.; Hong, Y.K.; Lee, H.; Chowdhury, M.T.; Choi, J.S.; Choi, I.S.; Moon, I.S. A brown alga Sargassum fulvellum facilitates neuronal maturation and synaptogenesis. In Vitro Cell. Dev. Biol. Anim. 2012, 48, 535-544. [CrossRef]

158. Hannan, M.A.; Mohibbullah, M.; Hwang, S.Y.; Lee, K.; Kim, Y.C.; Hong, Y.K.; Moon, I.S. Differential neuritogenic activities of two edible brown macroalgae, Undaria pinnatifida and Saccharina japonica. Am. J. Chin. Med. 2014, 42, 1371-1384. [CrossRef]

159. Mohibbullah, M.; Hannan, M.A.; Park, I.S.; Moon, I.S.; Hong, Y.K. The edible red seaweed Gracilariopsis chorda promotes axodendritic architectural complexity in hippocampal neurons. J. Med. Food 2016, 19, 638-644. [CrossRef]

160. Tirtawijaya, G.; Mohibbullah, M.; Meinita, M.D.N.; Moon, I.S.; Hong, Y.K. The tropical carrageenophyte Kappaphycus alvarezii extract promotes axodendritic maturation of hippocampal neurons in primary culture. J. Appl. Phycol. 2018, 30, 3233-3241. [CrossRef]

161. Tirtawijaya, G.; Mohibbullah, M.; Meinita, M.D.N.; Moon, I.S.; Hong, Y.K. The ethanol extract of the rhodophyte Kappaphycus alvarezii promotes neurite outgrowth in hippocampal neurons. J. Appl. Phycol. 2016, 28, 2515-2522. [CrossRef]

162. Tirtawijaya, G.; Haque, M.N.; Choi, J.S.; Moon, I.S.; Meinita, M.D.N.; Choi, J.S.; Hong, Y.K.; Science, F. Spinogenesis and synaptogenesis effects of the red seaweed Kappaphycus alvarezii and its isolated cholesterol on hippocampal neuron cultures. Prev. Nutr. Food Sci. 2019, 24, 418-425. [CrossRef] [PubMed]

163. Tirtawijaya, G.; Meinita, M.D.N.; Marhaeni, B.; Haque, M.N.; Moon, I.S.; Hong, Y.K. Neurotrophic activity of the Carrageenophyte Kappaphycus alvarezii cultivated at different depths and for different growth periods in various areas of indonesia. Evid. Based Complement. Alternat. Med. 2018, 2018, 1098076. [CrossRef] [PubMed]

164. Lin, J.; Yu, J.; Zhao, J.; Zhang, K.; Zheng, J.; Wang, J.; Huang, C.; Zhang, J.; Yan, X.; Gerwick, W.H.; et al. Fucoxanthin, a marine carotenoid, attenuates $\beta$-amyloid oligomer-induced neurotoxicity possibly via regulating the PI3K/Akt and the ERK pathways in SH-SY5Y cells. Oxid. Med. Cell. Longev. 2017, 2017, 6792543. [CrossRef]

165. Yu, J.; Lin, J.J.; Yu, R.; He, S.; Wang, Q.W.; Cui, W.; Zhang, J.R. Fucoxanthin prevents H(2)O(2)-induced neuronal apoptosis via concurrently activating the PI3-K/Akt cascade and inhibiting the ERK pathway. Food Nutr. Res. 2017, 61, 1304678. [CrossRef]

166. Ikeda, K.; Kitamura, A.; Machida, H.; Watanabe, M.; Negishi, H.; Hiraoka, J.; Nakano, T. Effect of Undaria pinnatifida (Wakame) on the development of cerebrovascular diseases in stroke-prone spontaneously hypertensive rats. Clin. Exp. Pharmacol. Physiol. 2003, 30, 44-48. [CrossRef]

167. Mohibbullah, M.; Haque, M.N.; Khan, M.N.A.; Park, I.S.; Moon, I.S.; Hong, Y.K. Neuroprotective effects of fucoxanthin and its derivative fucoxanthinol from the phaeophyte Undaria pinnatifida attenuate oxidative stress in hippocampal neurons. J. Appl. Phycol. 2018, 30, 3243-3252. [CrossRef]

168. Hu, L.; Chen, W.; Tian, F.; Yuan, C.; Wang, H.; Yue, H. Neuroprotective role of fucoxanthin against cerebral ischemic/reperfusion injury through activation of Nrf2/HO-1 signaling. Biomed. Pharmacother. 2018, 106, 1484-1489. [CrossRef]

169. Zhang, L.; Wang, H.; Fan, Y.; Gao, Y.; Li, X.; Hu, Z.; Ding, K.; Wang, Y.; Wang, X. Fucoxanthin provides neuroprotection in models of traumatic brain injury via the Nrf2-ARE and Nrf2-autophagy pathways. Sci. Rep. 2017, 7, 46763. [CrossRef] 
170. Shimizu, H.; Koyama, T.; Yamada, S.; Lipton, S.A.; Satoh, T. Zonarol, a sesquiterpene from the brown algae Dictyopteris undulata, provides neuroprotection by activating the Nrf2/ARE pathway. Biochem. Biophys. Res. Commun. 2015, 457, 718-722. [CrossRef]

171. Shanmuganathan, B.; Sathya, S.; Balasubramaniam, B.; Balamurugan, K.; Devi, K.P. Amyloid- $\beta$ induced neuropathological actions are suppressed by Padina gymnospora (Phaeophyceae) and its active constituent $\alpha$-bisabolol in Neuro2a cells and transgenic Caenorhabditis elegans Alzheimer's model. Nitric Oxide 2019, 91, 52-66. [CrossRef] [PubMed]

172. Oh, J.H.; Choi, J.S.; Nam, T.J. Fucosterol from an edible brown alga Ecklonia stolonifera prevents soluble amyloid beta-induced cognitive dysfunction in aging rats. Mar. Drugs 2018, 16, 368. [CrossRef] [PubMed]

173. Gan, S.Y.; Wong, L.Z.; Wong, J.W.; Tan, E.L. Fucosterol exerts protection against amyloid $\beta$-induced neurotoxicity, reduces intracellular levels of amyloid $\beta$ and enhances the mRNA expression of neuroglobin in amyloid $\beta$-induced SH-SY5Y cells. Int. J. Biol. Macromol. 2019, 121, 207-213. [CrossRef] [PubMed]

174. Yang, P.; Liu, D.Q.; Liang, T.J.; Li, J.; Zhang, H.Y.; Liu, A.H.; Guo, Y.W.; Mao, S.C. Bioactive constituents from the green alga Caulerpa racemosa. Bioorg. Med. Chem. 2015, 23, 38-45. [CrossRef] [PubMed]

175. Ahn, B.R.; Moon, H.E.; Kim, H.R.; Jung, H.A.; Choi, J.S. Neuroprotective effect of edible brown alga Eisenia bicyclis on amyloid beta peptide-induced toxicity in PC12 cells. Arch. Pharm. Res. 2012, 35, 1989-1998. [CrossRef] [PubMed]

176. Cui, Y.; Amarsanaa, K.; Lee, J.H.; Rhim, J.K.; Kwon, J.M.; Kim, S.H.; Park, J.M.; Jung, S.C.; Eun, S.Y. Neuroprotective mechanisms of dieckol against glutamate toxicity through reactive oxygen species scavenging and nuclear factor-like 2/heme oxygenase-1 pathway. Korean J. Physiol. Pharmacol. 2019, 23, 121-130. [CrossRef]

177. Yang, E.J.; Ahn, S.; Ryu, J.; Choi, M.S.; Choi, S.; Chong, Y.H.; Hyun, J.W.; Chang, M.J.; Kim, H.S. Phloroglucinol Attenuates the Cognitive Deficits of the 5XFAD Mouse Model of Alzheimer's Disease. PLoS ONE 2015, 10, e0135686. [CrossRef]

178. Kang, S.M.; Cha, S.H.; Ko, J.Y.; Kang, M.C.; Kim, D.; Heo, S.J.; Kim, J.S.; Heu, M.S.; Kim, Y.T.; Jung, W.K.; et al. Neuroprotective effects of phlorotannins isolated from a brown alga, Ecklonia cava, against H2O2-induced oxidative stress in murine hippocampal HT22 cells. Environ. Toxicol. Pharmacol. 2012, 34, 96-105. [CrossRef]

179. Heo, S.J.; Cha, S.H.; Kim, K.N.; Lee, S.H.; Ahn, G.; Kang, D.H.; Oh, C.; Choi, Y.U.; Affan, A.; Kim, D.; et al. Neuroprotective effect of phlorotannin isolated from Ishige okamurae against $\mathrm{H}_{2} \mathrm{O}_{2}$-induced oxidative stress in murine hippocampal neuronal cells, HT22. Appl. Biochem. Biotechnol. 2012, 166, 1520-1532. [CrossRef]

180. Kim, J.J.; Kang, Y.J.; Shin, S.A.; Bak, D.H.; Lee, J.W.; Lee, K.B.; Yoo, Y.C.; Kim, D.K.; Lee, B.H.; Kim, D.W.; et al. Phlorofucofuroeckol improves glutamate-induced neurotoxicity through modulation of oxidative stress-mediated mitochondrial dysfunction in PC12 cells. PLoS ONE 2016, 11, e0163433. [CrossRef]

181. Wang, J.; Zheng, J.; Huang, C.; Zhao, J.; Lin, J.; Zhou, X.; Naman, C.B.; Wang, N.; Gerwick, W.H.; Wang, Q.; et al. Eckmaxol, a phlorotannin extracted from Ecklonia maxima, Produces anti-beta-amyloid oligomer neuroprotective effects possibly via directly acting on glycogen synthase kinase 3 beta. ACS. Chem. Neurosci. 2018, 9, 1349-1356. [CrossRef]

182. Jhamandas, J.H.; Wie, M.B.; Harris, K.; MacTavish, D.; Kar, S. Fucoidan inhibits cellular and neurotoxic effects of beta-amyloid (A beta) in rat cholinergic basal forebrain neurons. Eur. J. Neurosci. 2005, 21, 2649-2659. [CrossRef] [PubMed]

183. Luo, D.; Zhang, Q.; Wang, H.; Cui, Y.; Sun, Z.; Yang, J.; Zheng, Y.; Jia, J.; Yu, F.; Wang, X.; et al. Fucoidan protects against dopaminergic neuron death in vivo and in vitro. Eur. J. Pharmacol. 2009, 617, $33-40$. [CrossRef] [PubMed]

184. Gao, Y.; Dong, C.; Yin, J.; Shen, J.; Tian, J.; Li, C. Neuroprotective effect of fucoidan on H2O2-induced apoptosis in PC12 cells via activation of PI3K/Akt pathway. Cell. Mol. Neurobiol. 2012, 32, 523-529. [CrossRef]

185. Wei, H.; Gao, Z.; Zheng, L.; Zhang, C.; Liu, Z.; Yang, Y.; Teng, H.; Hou, L.; Yin, Y.; Zou, X. Protective effects of fucoidan on A $\beta 25-35$ and d-Gal-induced neurotoxicity in PC12 cells and d-Gal-induced cognitive dysfunction in mice. Mar. Drugs 2017, 15, 77. [CrossRef]

186. Liang, Z.; Liu, Z.; Sun, X.; Tao, M.; Xiao, X.; Yu, G.; Wang, X. The Effect of Fucoidan on cellular oxidative stress and the CatD-Bax signaling axis in MN9D cells damaged by 1-Methyl-4-Phenypyridinium. Front. Aging Neurosci. 2019, 10, 429. [CrossRef]

187. Wu, H.; Gao, S.; Terakawa, S. Inhibitory effects of fucoidan on NMDA receptors and l-type Ca(2+) channels regulating the $\mathrm{Ca}(2+)$ responses in rat neurons. Pharm. Biol. 2019, 57, 1-7. [CrossRef] 
188. Liu, Y.; Deng, Z.; Geng, L.; Wang, J.; Zhang, Q. In vitro evaluation of the neuroprotective effect of oligo-porphyran from Porphyra yezoensis in PC12 cells. J. Appl. Phycol. 2019, 31, 2559-2571. [CrossRef]

189. Wang, S.; Li, J.; Xia, W.; Geng, M. A marine-derived acidic oligosaccharide sugar chain specifically inhibits neuronal cell injury mediated by beta-amyloid-induced astrocyte activation in vitro. Neurol. Res. 2007, 29, 96-102. [CrossRef] [PubMed]

190. Liu, D.Q.; Mao, S.C.; Zhang, H.Y.; Yu, X.Q.; Feng, M.T.; Wang, B.; Feng, L.H.; Guo, Y.W. Racemosins A and B, two novel bisindole alkaloids from the green alga Caulerpa racemosa. Fitoterapia 2013, 91, 15-20. [CrossRef]

191. Wu, S.; Yue, Y.; Tian, H.; Tao, L.; Wang, Y.; Xiang, J.; Wang, S.; Ding, H. Tramiprosate protects neurons against ischemic stroke by disrupting the interaction between PSD95 and nNOS. Neuropharmacology 2014, 83, 107-117. [CrossRef] [PubMed]

192. Liu, Y.; Jiang, L.; Li, X. K-carrageenan-derived pentasaccharide attenuates A $\beta 25-35$-induced apoptosis in SH-SY5Y cells via suppression of the JNK signaling pathway. Mol. Med. Rep. 2017, 15, 285-290. [CrossRef] [PubMed]

193. Gao, Y.; Li, C.; Yin, J.; Shen, J.; Wang, H.; Wu, Y.; Jin, H. Fucoidan, a sulfated polysaccharide from brown algae, improves cognitive impairment induced by infusion of $\mathrm{A} \beta$ peptide in rats. Environ. Toxicol. Pharmacol. 2012, 33, 304-311. [CrossRef] [PubMed]

194. Wang, X.; Yi, K.; Zhao, Y. Fucoidan inhibits amyloid- $\beta$-induced toxicity in transgenic Caenorhabditis elegans by reducing the accumulation of amyloid- $\beta$ and decreasing the production of reactive oxygen species. Food Funct. 2018, 9, 552-560. [CrossRef] [PubMed]

195. Park, S.K.; Kang, J.Y.; Kim, J.M.; Yoo, S.K.; Han, H.J.; Chung, D.H.; Kim, D.O.; Kim, G.H.; Heo, H.J. Fucoidan-rich substances from ecklonia cava improve trimethyltin-induced cognitive dysfunction via down-regulation of amyloid $\beta$ production/Tau hyperphosphorylation. Mar. Drugs 2019, 17, 591. [CrossRef]

196. Kim, H.; Ahn, J.H.; Song, M.; Kim, D.W.; Lee, T.K.; Lee, J.C.; Kim, Y.M.; Kim, J.D.; Cho, J.H.; Hwang, I.K.; et al. Pretreated fucoidan confers neuroprotection against transient global cerebral ischemic injury in the gerbil hippocampal CA1 area via reducing of glial cell activation and oxidative stress. Biomed. Pharmacother. 2019, 109, 1718-1727. [CrossRef]

197. Lee, T.K.; Ahn, J.H.; Park, C.W.; Kim, B.; Park, Y.E.; Lee, J.C.; Park, J.H.; Yang, G.E.; Shin, M.C.; Cho, J.H.; et al. Pre-treatment with laminarin protects hippocampal ca1 pyramidal neurons and attenuates reactive gliosis following transient forebrain ischemia in gerbils. Mar. Drugs 2020, 18, 52. [CrossRef]

198. Park, J.H.; Ahn, J.H.; Lee, T.K.; Park, C.W.; Kim, B.; Lee, J.C.; Kim, D.W.; Shin, M.C.; Cho, J.H.; Lee, C.H.; et al. Laminarin pretreatment provides neuroprotection against forebrain ischemia/reperfusion injury by reducing oxidative stress and neuroinflammation in aged gerbils. Mar. Drugs 2020, 18, 213. [CrossRef]

199. Liu, Y.; Geng, L.; Zhang, J.; Wang, J.; Zhang, Q.; Duan, D.; Zhang, Q. Oligo-Porphyran ameliorates neurobehavioral deficits in parkinsonian mice by regulating the PI3K/Akt/Bcl-2 pathway. Mar. Drugs 2018, 16, 82. [CrossRef]

200. Zhang, Z.; Wang, X.; Pan, Y.; Wang, G.; Mao, G. The degraded polysaccharide from Pyropia haitanensis represses amyloid beta peptide-induced neurotoxicity and memory in vivo. Int. J. Biol. Macromol. 2020, 146, 725-729. [CrossRef]

201. Pentón-Rol, G.; Marín-Prida, J.; Pardo-Andreu, G.; Martínez-Sánchez, G.; Acosta-Medina, E.F.; Valdivia-Acosta, A.; Lagumersindez-Denis, N.; Rodríguez-Jiménez, E.; Llópiz-Arzuaga, A.; López-Saura, P.A.; et al. C-Phycocyanin is neuroprotective against global cerebral ischemia/reperfusion injury in gerbils. Brain. Res. Bull. 2011, 86, 42-52. [CrossRef] [PubMed]

202. Souza, R.B.; Frota, A.F.; Sousa, R.S.; Cezario, N.A.; Santos, T.B.; Souza, L.M.; Coura, C.O.; Monteiro, V.S.; Cristino Filho, G.; Vasconcelos, S.M.; et al. Neuroprotective effects of sulphated agaran from marine alga Gracilaria cornea in Rat 6-Hydroxydopamine parkinson's disease model: Behavioural, neurochemical and transcriptional alterations. Basic Clin. Pharmacol. Toxicol. 2017, 120, 159-170. [CrossRef] [PubMed]

203. Zhou, X.; Yi, M.; Ding, L.; He, S.; Yan, X. Isolation and purification of a neuroprotective phlorotannin from the marine algae Ecklonia maxima by size exclusion and high-speed counter-current chromatography. Mar. Drugs 2019, 17, 212. [CrossRef] [PubMed]

204. Dimitrova-Shumkovska, J.; Krstanoski, L.; Veenman, L. Potential beneficial actions of fucoidan in brain and liver injury, disease, and intoxication-Potential implication of sirtuins. Mar. Drugs 2020, 18, 242. [CrossRef] [PubMed] 
205. Yang, W.N.; Chen, P.W.; Huang, C.Y. Compositional characteristics and in vitro evaluations of antioxidant and neuroprotective properties of crude extracts of fucoidan prepared from compressional puffing-pretreated Sargassum crassifolium. Mar. Drugs 2017, 15, 183. [CrossRef] [PubMed]

206. Huang, C.Y.; Kuo, C.H.; Chen, P.W. Compressional-puffing pretreatment enhances neuroprotective effects of fucoidans from the brown seaweed Sargassum hemiphyllum on 6-Hydroxydopamine-induced apoptosis in SH-SY5Y cells. Molecules 2017, 23, 78. [CrossRef]

207. Souza, R.B.; Frota, A.F.; Silva, J.; Alves, C.; Neugebauer, A.Z.; Pinteus, S.; Rodrigues, J.A.G.; Cordeiro, E.M.S.; de Almeida, R.R.; Pedrosa, R.; et al. In vitro activities of kappa-carrageenan isolated from red marine alga Hypnea musciformis: Antimicrobial, anticancer and neuroprotective potential. Int. J. Biol. Macromol. 2018, 112, 1248-1256. [CrossRef]

208. Tsang, C.K.; Kamei, Y. Sargaquinoic acid supports the survival of neuronal PC12D cells in a nerve growth factor-independent manner. Eur. J. Pharmacol. 2004, 488, 11-18. [CrossRef]

209. Tsolaki, M. Future strategies of management of Alzheimer's Disease. The role of homotaurine. Hell. J. Nucl. Med. 2019, 22, 82-94.

210. Ricciardi, L.; De Nigris, F.; Specchia, A.; Fasano, A. Homotaurine in Parkinson's disease. Neurol. Sci. 2015, 36, 1581-1587. [CrossRef]

211. Oh, J.H.; Kim, E.Y.; Nam, T.J. Phycoerythrin peptide from Pyropia yezoensis alleviates endoplasmic reticulum stress caused by perfluorooctane sulfonate-induced calcium dysregulation. Mar. Drugs 2018, 16, 44. [CrossRef] [PubMed]

212. Oh, J.H.; Kim, E.Y.; Nam, T.J. Phycoerythrin-derived tryptic peptide of a red alga Pyropia yezoensis attenuates glutamate-induced er stress and neuronal senescence in primary rat hippocampal neurons. Mol. Nutr. Food Res. 2018, 62, e1700469. [CrossRef] [PubMed]

213. Liu, D.L.; Zhang, H.; Feng, M.; Yang, H.; Yang, P.; Lin, K.; Guo, Y.; Mao, S. The fatty acids of green alga Caulerpa racemosa and their bioactivities. Zhongguo Haiyang Yaowu 2013, 32, 13-20.

214. Silva, J.; Alves, C.; Pinteus, S.; Mendes, S.; Pedrosa, R. Neuroprotective effects of seaweeds against 6-hydroxidopamine-induced cell death on an in vitro human neuroblastoma model. BMC Complement. Altern. Med. 2018, 18, 58. [CrossRef]

215. Silva, J.; Alves, C.; Freitas, R.; Martins, A.; Pinteus, S.; Ribeiro, J.; Gaspar, H.; Alfonso, A.; Pedrosa, R. Antioxidant and neuroprotective potential of the brown seaweed Bifurcaria bifurcata in an in vitro Parkinson's Disease model. Mar. Drugs 2019, 17, 85. [CrossRef]

216. Chacko, A.; Ittiyavirah, S.P. Pharmacology, neuroprotective effect of against aluminium-induced Gracilaria corticata neurotoxicity in the hippocampus and cerebral cortex of rat brain: Biochemical and histological approach. J. Pharm. Pharmacol. 2019, 5, 604-613.

217. Alghazwi, M.; Smid, S.; Zhang, W. In vitro protective activity of South Australian marine sponge and macroalgae extracts against amyloid beta $(\mathrm{A} \beta(1-42))$ induced neurotoxicity in PC-12 cells. Neurotoxicol. Teratol. 2018, 68, 72-83. [CrossRef]

218. Kim, J.; Moon, I.S.; Goo, T.W.; Moon, S.S.; Seo, M. Algae Undaria pinnatifida protects hypothalamic neurons against endoplasmic reticulum stress through Akt/mTOR signaling. Molecules 2015, 20, 20998-21009. [CrossRef]

219. Mohibbullah, M.; Hannan, M.A.; Choi, J.Y.; Bhuiyan, M.M.H.; Hong, Y.K.; Choi, J.S.; Choi, I.S.; Moon, I.S. The edible marine alga Gracilariopsis chorda alleviates hypoxia/reoxygenation-induced oxidative stress in cultured hippocampal neurons. J. Med. Food 2015, 18, 960-971. [CrossRef] [PubMed]

220. Yang, Y.; Yang, I.; Cao, M.; Su, Z.Y.; Wu, R.; Guo, Y.; Fang, M.; Kong, A.N. Fucoxanthin elicits epigenetic modifications, nrf2 activation and blocking transformation in mouse skin JB6 P+ Cells. AAPS J. 2018, 20, 32. [CrossRef]

221. Oh, J.H.; Nam, T.J. Hydrophilic glycoproteins of an edible green alga Capsosiphon fulvescens prevent aging-induced spatial memory impairment by suppressing gsk-3beta-mediated er stress in dorsal hippocampus. Mar. Drugs 2019, 17, 168. [CrossRef] [PubMed]

222. Oh, J.H.; Nam, T.J.; Choi, Y.H. Capsosiphon fulvescens Glycoproteins Enhance Probiotics-Induced Cognitive Improvement in Aged Rats. Nutrients 2020, 12, 837. [CrossRef] [PubMed]

223. Nisha, S.A.; Devi, K.P. Gelidiella acerosa protects against A $\beta$ 25-35-induced toxicity and memory impairment in Swiss Albino mice: An in vivo report. Pharm. Biol. 2017, 55, 1423-1435. [CrossRef] [PubMed] 
224. Siddiqui, P.J.A.; Khan, A.; Uddin, N.; Khaliq, S.; Rasheed, M.; Nawaz, S.; Dar, A.; Hanif, M. Sargassum swartzii extracts ameliorate memory functions by neurochemical modulation in a rat model. Food Sci. Biotechnol. 2017, 26, 1055-1062. [CrossRef] [PubMed]

225. Choi, J.Y.; Mohibbullah, M.; Park, I.S.; Moon, I.S.; Hong, Y.K. An ethanol extract from the phaeophyte Undaria pinnatifida improves learning and memory impairment and dendritic spine morphology in hippocampal neurons. J. Appl. Phycol. 2018, 30, 129-136. [CrossRef]

226. El-Baz, F.K.; Aly, H.F.; Ali, G.H. Haematococcus pluvialis modulating effect on neurotransmitters, hormones and oxidative damage-associated with alzheimers disease in experimental rats model. Int. J. Pharm. Pharm. Sci. 2017, 9, 198-206. [CrossRef]

227. Choi, W.Y.; Kang, D.H.; Heo, S.J.; Lee, H.Y. Enhancement of the neuroprotective effect of fermented Spirulina maxima associated with antioxidant activities by ultrasonic extraction. Appl. Sci. 2018, 8, 2469. [CrossRef]

228. Kim, J.H.; Lee, N.S.; Jeong, Y.G.; Lee, J.H.; Kim, E.J.; Han, S.Y. Protective efficacy of an Ecklonia cava extract used to treat transient focal ischemia of the rat brain. Anat. Cell. Biol. 2012, 45, 103-113. [CrossRef] [PubMed]

229. Jiang, R.W.; Du, X.G.; Zhang, X.; Wang, X.; Hu, D.Y.; Meng, T.; Chen, Y.L.; Geng, M.Y.; Shen, J.K. Synthesis and bioassay of $\beta-(1,4)-\mathrm{D}-\mathrm{mannans}$ as potential agents against Alzheimer's disease. Acta Pharmacol. Sin. 2013, 34, 1585-1591. [CrossRef]

230. Wang, X.; Sun, G.; Feng, T.; Zhang, J.; Huang, X.; Wang, T.; Xie, Z.; Chu, X.; Yang, J.; Wang, H.; et al. Sodium oligomannate therapeutically remodels gut microbiota and suppresses gut bacterial amino acids-shaped neuroinflammation to inhibit Alzheimer's disease progression. Cell Res. 2019, 29, 787-803. [CrossRef]

231. Xiao, S. A phase II clinical trial on GV-971 in patients with Alzheimer's [abstract no. OC 3]. J. Prev. Alz. Dis. 2014, 1, 214-296.

232. Xiao, S.; Zhang, Z.; Geng, M. Phase 3 Clinical trial of a novel and multi-targeted oligosaccharide in patients with mildmoderate ad in china. China J. Prev. Alzheimers Dis. 2018, 5, S10.

233. Davis, G.D.; Vasanthi, A.H. Seaweed metabolite database (SWMD): A database of natural compounds from marine algae. Bioinformation 2011, 5, 361-364. [CrossRef] [PubMed]

234. Lei, J.; Zhou, J. A marine natural product database. J. Chem. Inf. Comput. Sci. 2002, 42, 742-748. [CrossRef]

235. Babu, P.A.; Puppala, S.S.; Aswini, S.L.; Vani, M.R.; Kumar, C.N.; Prasanna, T. A database of natural products and chemical entities from marine habitat. Bioinformation 2008, 3, 142-143. [CrossRef]

236. Barbosa, A.J.M.; Roque, A.C.A. Free marine natural products databases for biotechnology and bioengineering. Biotechnol. J. 2019, 14, 1800607. [CrossRef]

237. Dictionary of Marine Natural Products. Available online: http://dmnp.chemnetbase.com/faces/chemical/ ChemicalSearch.xhtml (accessed on 20 May 2020).

238. MarinLit, A Database of the Marine Natural Products Literature. Available online: http://pubs.rsc.org/marinlit (accessed on 20 May 2020).

239. Keller, T.H.; Pichota, A.; Yin, Z. A practical view of 'druggability'. Curr. Opin. Chem. Biol. 2006, 10, $357-361$. [CrossRef]

240. Wale, N.; Karypis, G. Target fishing for chemical compounds using target-ligand activity data and ranking based methods. J. Chem. Inf. Model. 2009, 49, 2190-2201. [CrossRef]

241. Huang, H.; Zhang, G.; Zhou, Y.; Lin, C.; Chen, S.; Lin, Y.; Mai, S.; Huang, Z. Reverse screening methods to search for the protein targets of chemopreventive compounds. Front. Chem. 2018, 6, 138. [CrossRef]

242. Dunkel, M.; Fullbeck, M.; Neumann, S.; Preissner, R. SuperNatural: A searchable database of available natural compounds. Nucleic Acids Res. 2006, 34, D678-D683. [CrossRef]

243. Huang, L.; Xie, D.; Yu, Y.; Liu, H.; Shi, Y.; Shi, T.; Wen, C. TCMID 2.0: A comprehensive resource for TCM. Nucleic Acids Res. 2017, 46, D1117-D1120. [CrossRef] [PubMed]

244. Ru, J.; Li, P.; Wang, J.; Zhou, W.; Li, B.; Huang, C.; Li, P.; Guo, Z.; Tao, W.; Yang, Y.; et al. TCMSP: A database of systems pharmacology for drug discovery from herbal medicines. J. Cheminform. 2014, 6, 13. [CrossRef] [PubMed]

245. Pereira, F.; Aires-de-Sousa, J. Computational methodologies in the exploration of marine natural product leads. Mar. Drugs 2018, 16, 236. [CrossRef] [PubMed]

246. Sorokina, M.; Steinbeck, C. Review on natural products databases: Where to find data in 2020. J. Cheminform. 2020, 12, 20. [CrossRef] 
247. Vitale, R.M.; D'Aniello, E.; Gorbi, S.; Martella, A.; Silvestri, C.; Giuliani, M.E.; Fellous, T.; Gentile, A.; Carbone, M.; Cutignano, A.; et al. Fishing for targets of alien metabolites: A novel peroxisome proliferator-activated receptor (PPAR) agonist from a marine pest. Mar. Drugs 2018, 16, 431. [CrossRef]

248. Chamberlin, S.R.; Blucher, A.; Wu, G.; Shinto, L.; Choonoo, G.; Kulesz-Martin, M.; McWeeney, S. Natural product target network reveals potential for cancer combination therapies. Front. Pharmacol. 2019, 10, 557. [CrossRef] [PubMed]

249. Jung, H.A.; Roy, A.; Choi, J.S. In vitro monoamine oxidase A and B inhibitory activity and molecular docking simulations of fucoxanthin. Fish. Sci. 2017, 83, 123-132. [CrossRef]

250. Paudel, P.; Seong, S.H.; Jung, H.A.; Choi, J.S. Characterizing fucoxanthin as a selective dopamine $\mathrm{D}(3) / \mathrm{D}(4)$ receptor agonist: Relevance to Parkinson's disease. Chem. Biol. Interact. 2019, 310, 108757. [CrossRef]

251. Paudel, P.; Park, S.E.; Seong, S.H.; Jung, H.A.; Choi, J.S. Bromophenols from symphyocladia latiuscula target human monoamine oxidase and dopaminergic receptors for the management of neurodegenerative diseases. J. Agric. Food Chem. 2020, 68, 2426-2436. [CrossRef]

252. Floresta, G.; Amata, E.; Barbaraci, C.; Gentile, D.; Turnaturi, R.; Marrazzo, A.; Rescifina, A. A Structure- and Ligand-Based Virtual Screening of a Database of "Small" Marine Natural Products for the Identification of "Blue" Sigma-2 Receptor Ligands. Mar. Drugs 2018, 16, 10. [CrossRef]

253. Sá Monteiro, M.; Sloth, J.J.; Holdt, S.L.; Hansen, M. Analysis and risk assessment of seaweed. EFSA J. 2019, 17, e170915.

254. Hwang, P.A.; Yan, M.D.; Lin, H.T.; Li, K.L.; Lin, Y.C. Toxicological evaluation of low molecular weight fucoidan in vitro and in vivo. Mar. Drugs 2016, 14, 7. [CrossRef] [PubMed]

255. Li, N.; Zhang, Q.; Song, J. Toxicological evaluation of fucoidan extracted from Laminaria japonica in Wistar rats. Food Chem. Toxicol. 2005, 43, 421-426. [CrossRef] [PubMed]

256. Chung, H.J.; Jeun, J.; Houng, S.J.; Jun, H.J.; Kweon, D.K.; Lee, S.J. Toxicological evaluation of fucoidan from Undaria pinnatifida in vitro and in vivo. Phytother. Res. 2010, 24, 1078-1083. [PubMed]

257. Kim, K.J.; Lee, O.H.; Lee, B.Y. Genotoxicity studies on fucoidan from Sporophyll of Undaria pinnatifida. Food Chem. Toxicol. 2010, 48, 1101-1104. [CrossRef]

258. Kim, K.J.; Lee, O.H.; Lee, H.H.; Lee, B.Y. A 4-week repeated oral dose toxicity study of fucoidan from the Sporophyll of Undaria pinnatifida in Sprague-Dawley rats. Toxicology 2010, 267, 154-158. [CrossRef]

259. Myers, S.P.; O'Connor, J.; Fitton, J.H.; Brooks, L.; Rolfe, M.; Connellan, P.; Wohlmuth, H.; Cheras, P.A.; Morris, C. A combined phase I and II open label study on the effects of a seaweed extract nutrient complex on osteoarthritis. Biologics 2010, 4, 33-44. [CrossRef]

260. Myers, S.P.; Mulder, A.M.; Baker, D.G.; Robinson, S.R.; Rolfe, M.I.; Brooks, L.; Fitton, J.H. Effects of fucoidan from fucus vesiculosus in reducing symptoms of osteoarthritis: A randomized placebo-controlled trial. Biologics 2016, 10, 81-88.

261. Weiner, M.L. Food additive carrageenan: Part II: A critical review of carrageenan in vivo safety studies. Crit. Rev. Toxicol. 2014, 44, 244-269. [CrossRef]

262. Hebar, A.; Koller, C.; Seifert, J.M.; Chabicovsky, M.; Bodenteich, A.; Bernkop-Schnurch, A.; Grassauer, A.; Prieschl-Grassauer, E. Non-clinical safety evaluation of intranasal iota-carrageenan. PLoS ONE 2015, 10, e0122911. [CrossRef]

263. Beppu, F.; Niwano, Y.; Tsukui, T.; Hosokawa, M.; Miyashita, K. Single and repeated oral dose toxicity study of fucoxanthin (FX), a marine carotenoid, in mice. J. Toxicol. Sci. 2009, 34, 501-510. [CrossRef] [PubMed]

264. Kadekaru, T.; Toyama, H.; Yasumoto, T. Safety Evaluation of Fucoxanthin purified from Undaria pinnatifida. Nippon Shokuhin Kagaku Kogaku Kaishi 2008, 55, 304-308. [CrossRef]

265. Beppu, F.; Niwano, Y.; Sato, E.; Kohno, M.; Tsukui, T.; Hosokawa, M.; Miyashita, K. In vitro and in vivo evaluation of mutagenicity of fucoxanthin (FX) and its metabolite fucoxanthinol (FXOH). J. Toxicol. Sci. 2009, 34, 693-698. [CrossRef] [PubMed]

(C) 2020 by the authors. Licensee MDPI, Basel, Switzerland. This article is an open access article distributed under the terms and conditions of the Creative Commons Attribution (CC BY) license (http://creativecommons.org/licenses/by/4.0/). 